\title{
ESTUDO DA VIDA ÚTIL DA BISTECA SUÍNA EM ATMOSFERA MODIFICADA
}

\author{
KARINA GEBRIN BACHION \\ Médica Veterinária
}

Orientadora: Prof $^{a}$.Dr ${ }^{\mathrm{a}}$. MARÍLIA OETTERER

Dissertaçăo apresentada à Escola Superior de Agricultura "Luiz de Queiroz", Universidade de São Paulo, para obtenção do título de Mestre em Ciências, Área de Concentração: Ciência e Tecnologia de Alimentos.

PIRACICABA

Estado de São Paulo - Brasil

Agosto - 2004 


\section{ERRATA}

KARINA GEBRIN BACHION. Estudo da vida útil da bisteca suína em atmosfera modificada

\begin{tabular}{|c|c|c|c|c|}
\hline p. & item & linha & onde se lê & leia-se \\
\hline$x i i$ & 4 e 5 & $\begin{array}{l}\text { Sétima e } \\
\text { décima }\end{array}$ & $0 \pm 2{ }^{\circ} \mathrm{C}$ & $0+3^{\circ} \mathrm{C}$ \\
\hline 7 & 2.1 .2 & vigésima & .........SARANTOPOULOS \& SOLER, 1998).... & .......SARANTOPOULOS \& SOLER, 1988).... \\
\hline 26 & 2.3 .5 & $\begin{array}{l}\text { Vigésima } \\
\text { terceira }\end{array}$ & .....(SARANTOPOULOS et al., 2001)..... & $\ldots . . .($ SARANTOPOULOS et al., 2002)..... \\
\hline 40 & 3.9 & oitava & ...os termos sugeridos no parágrafo anterior... & $\begin{array}{l}\text {...os termos sugeridos de acordo com } 0 \text { autor } \\
\text { do parágrafo anterior.... }\end{array}$ \\
\hline 44 & 4.1 & Segunda & $\begin{array}{l}\text {.....mostraram que o crescimento foi } \\
\text { induzido.... }\end{array}$ & $\begin{array}{l}\text {...mostraram que o crescimento de Listeria } \\
\text { monocytogenes foi induzido..... }\end{array}$ \\
\hline 45 & 4.1 & Terceira & $\begin{array}{l}\text {...mediram os valores (em grama) da } \\
\text { microbiota..... }\end{array}$ & $\begin{array}{l}\text {....mediram os valores em UFC } / g \text { da } \\
\text { microbiota.... }\end{array}$ \\
\hline 45 & 4.1 & Décima & ......a hipótese da sua existência durante..... & ....a hipótese da sua sobrevivência durante..... \\
\hline 47 & 4.1 & $\begin{array}{l}\text { Quarta, quinta } \\
\text { e sétima }\end{array}$ & ....log de UFC para o tratamento..... & ....log de UFC/g para o tratamento...... \\
\hline 53 & 4.1 & nona & ...enterobactérias (Figura 6 em anexo)...... & ....enterobactérias (Tabela $6 \mathrm{em}$ anexo)...... \\
\hline 55 & 4.1 & $\begin{array}{l}\text { Vigésima } \\
\text { primeira }\end{array}$ & $\ldots($ Figura 7 em anexo).... & $\ldots($ Tabela 7 em anexo $) \ldots$. \\
\hline 57 & 4.2 & Quadro 1 & .....PEBD/EVOH.... & ......PEBD/EVOH/PA..... \\
\hline 67 & 4.6 & $\begin{array}{l}\text { Vigésima } \\
\text { terceira e } \\
\text { vigésima } \\
\text { sexta.... }\end{array}$ & $\begin{array}{l}\ldots \ldots \text { média de TBA }(0,026) \ldots \ldots . \text { média de TBA } \\
(0,051) \ldots \ldots\end{array}$ & $\begin{array}{l}\ldots \ldots \ldots \ldots \text { média de TBA }(0,026 \mathrm{mg} / \mathrm{kg}) \ldots \ldots \ldots . . \mathrm{e} \\
\text { média de TBA }(0,051 \mathrm{mg} / \mathrm{kg}) \ldots \ldots\end{array}$ \\
\hline 76 & 4.7 & $\begin{array}{l}\text { Décima } \\
\text { segunda }\end{array}$ & $\begin{array}{l}\text {......"Cor amarela da gordura" }(0,5) \text { e } \\
\text { diferiu...... }\end{array}$ & $\begin{array}{l}\text { "Cor amarela da gordura" }(0,9) \text { e } \\
\text { diferiu..... }\end{array}$ \\
\hline
\end{tabular}




\section{Dados Internacionais de Catalogação na Publicação (CIP) DIVISÃO DE BIBLIOTECA E DOCUMENTAÇĀO - ESALQ/USP}

\section{Bachion, Karina Gebrin}

Estudo da vida útil da bisteca suína em atmosfera modificada / Karina Gebrin Bachion. - - Piracicaba, 2004.

$109 \mathrm{p}$.

Dissertação (mestrado) - - Escola Superior de Agricultura Luiz de Queiroz, 2004. Bibliografia.

1. Armazenagem em atmosfera modificada 2. Carne suina 3. Qualidade dos alimentos 4. Vida-de-prateleira I. Título

CDD 664.92

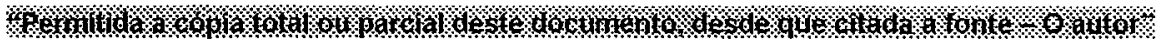


À minha famífia, 6ase da minha vida, Dedico 


\section{AGRADECIMENTOS}

À Deus, por cada segundo de minha vida;

Aos meus pais, por tornarem possiveis todos os meus sonhos;

Ao meu irmão Erich, por me incentivar e me ajudar;

À Coordenadoria de Aperfeiçoamento do Pessoal de Ensino Superior (CAPES), pela bolsa de estudos concedida durante o curso de mestrado;

À Fundação de Apoio a Pesquisa (FAPESP), pelo patrocínio a realização deste trabalho;

Ao meu orientador, Dr.Expedito Tadeu Facco Silveira, pela amizade, apoio, orientação, ensinamentos e a oportunidade para a realização deste trabalho;

Ao Instituto de Tecnologia de Alimentos (ITAL), em especial ao Dr. Nelson José Beraquet, do Centro de Tecnologia de Carnes (CTC), pela possibilidade da realização deste trabalho em suas instalações;

A todos os pesquisadores do CTC-ITAL, pela inestimável contribuição e amizade;

A Ms. Kátia B. P. Cipolli pela orientação, apoio e incentivo nas análises sensoriais;

A Ms. Luciana Myiaguski, pela orientação, apoio e incentivo nas análises físicoquímicas;

A todos os técnicos e funcionários do CTC-ITAL, especialmente a Célia, Ivonete, Gilca, Rose, Maristela, Márcia Cucatti, Nelson, Nilda, Maria Solenir e Sandra, pela amizade e apoio durante minha permanência no Instituto; 
A todos os estagiários do CTC-ITAL, principalmente a Débora, Hérica, Daniela, Juliana Cunha, Andréia locca, Carlos, Rodrigo, André e Gustavo pela amizade e apoio na realização deste trabalho;

Aos amigos dessa jornada em Campinas, Márcia Mayumi, Marcela Rezende da Costa, Maristela Silva do Nascimento e Walter Bergamim Filho, pelos momentos de alegria e dificuldades vivenciados;

A todos os professores da Escola Superior de Agricultura "Luiz de Queiroz" (ESALQ/USP), pelos conhecimentos transmitidos;

Aos funcionários do Departamento de Agroindústria, Alimentos e Nutrição, pela amizade;

A todos os meus colegas de Mestrado, especialmente Andréa Penatti e Fabiana Vieira, por proporcionarem momentos de alegria e me ajudarem nos momentos mais difíceis durante o curso;

À White Martins, pela concessão dos cilindros de gases utilizados neste trabalho;

À Cryovac, pela concessão das bandejas utilizadas neste trabalho;

À Pulit Embalagens, pela concessão das embalagens primárias utilizadas neste trabalho;

À Univac, pela concessão das embalagens secundárias utilizadas neste trabalho;

A todas as pessoas, que de alguma forma, colaboraram para a realização dos meus objetivos. 


\section{SUMÁRIO}

Página

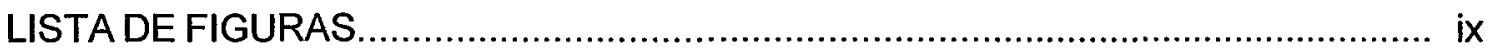

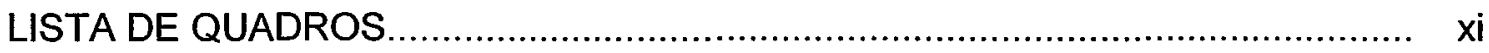

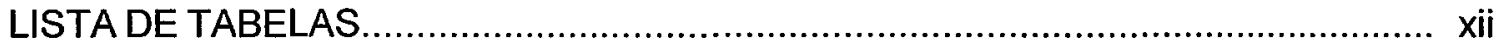

RESUMO

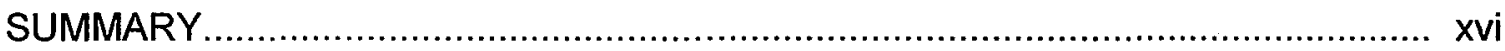

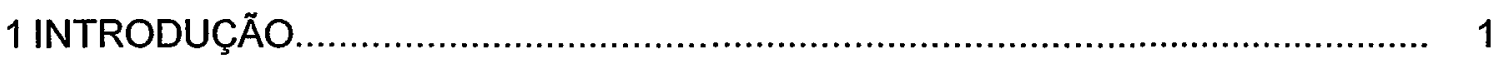

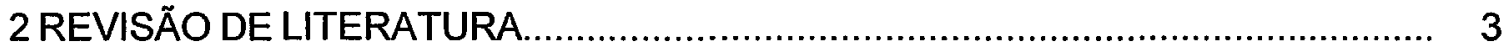

2.1 Microbiologia da carne in natura................................................................ 3

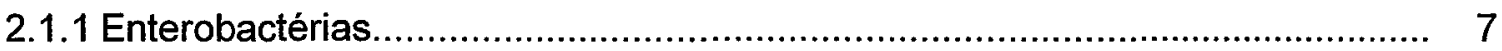

2.1.2 Microrganismos psicrotróficos aeróbios....................................................... 7

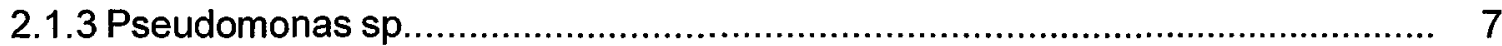

2.1.4 Bactérias lácticas................................................................................. 8

2.1.5 Coliformes fecais..................................................................................... 9

2.1.6 Contagem total de microrganismos mesófilos aeróbios ................................. 9

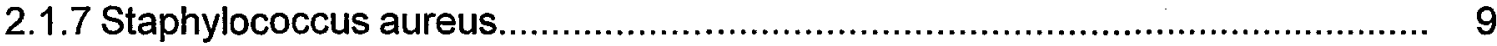

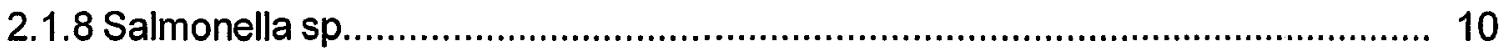

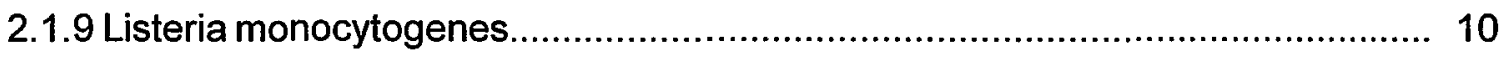

2.2 Alterações nas características físico-químicas da carne in natura..................... 11

2.2.1 Cor da carne in natura............................................................................. 11

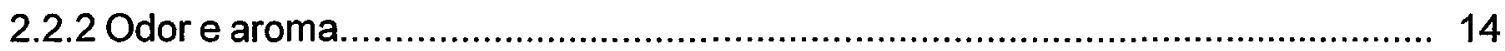

2.2.3 Indice de rancificação (valores de TBA) ...................................................... 14

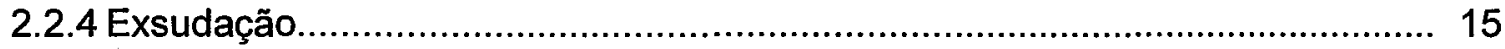

2.3 Utilização de Atmosfera Modificada (ATM) como sistema de preservação de carnes e produtos cárneos. 
2.3.1 Natureza e qualidade inicial do produto 16

2.3.2 Adequação da mistura gasosa em relação ao produto e à embalagem 17

2.3.2.1 Oxigênio $\left(\mathrm{O}_{2}\right)$ 17

2.3.2.2 Nitrogênio $\left(\mathrm{N}_{2}\right)$ 19

2.3.2.3 Dióxido de Carbono $\left(\mathrm{CO}_{2}\right)$. 19

2.3.3 Controle rigoroso da temperatura de estocagem, distribuição e comercialização.. 21

2.3.4 Propriedades da embalagem. 23

2.3.5 Sistema e equipamento de acondicionamento eficientes. 25

3 MATERIAL E MÉTODOS. 28

3.1 Acondicionamento do produto 28

3.2 Delineamento do experimento. 29

3.3 Determinação microbiológica da matéria-prima............................................... 30

3.3.1 Salmonella sp. 30

3.3.2 Coliformes fecais. 31

3.3.3 Staphylococcus aureus. 32

3.3.4 Listeria monocytogenes. 32

3.3.5 Contagem padrão de microrganismos mesófilos aeróbios totais. 33

3.3.6 Bactérias lácticas. 33

3.3.7 Enterobactérias. 34

3.3.8 Microrganismos psicrotróficos aeróbios 34

3.3.9 Pseudomonas $\mathrm{sp}$ 35

3.4 Caracterização das embalagens. 37

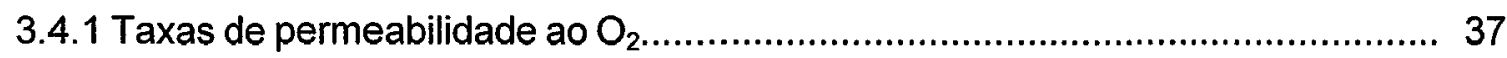

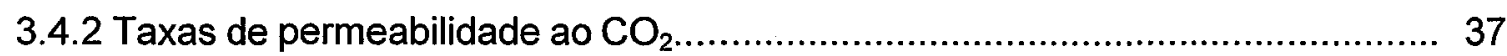

3.5 Análise da composição gasosa do espaço livre................................................ 38

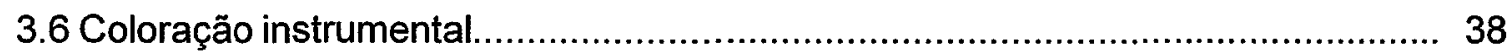

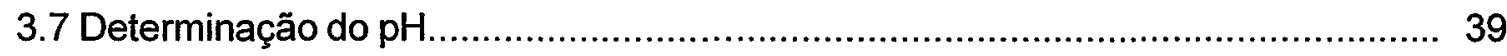

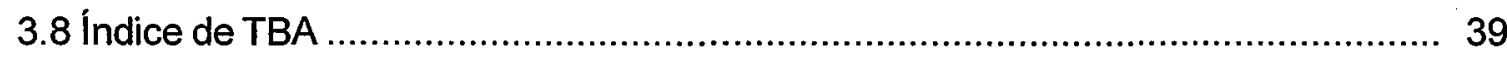

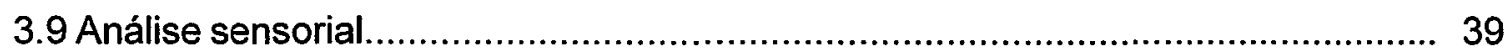

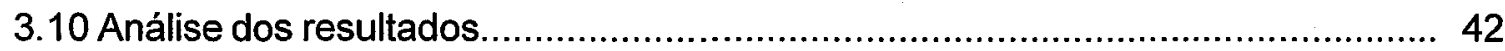

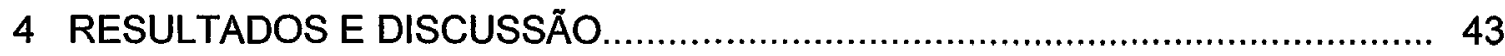




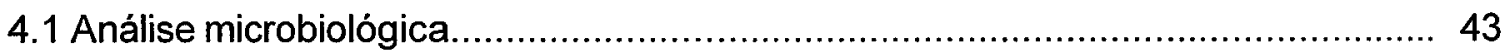

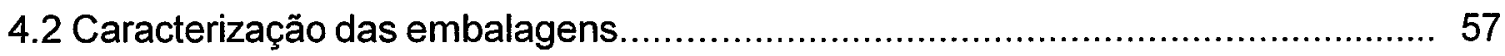

4.3 Análise da composição gasosa do espaço-livre.............................................. 58

4.4 Avaliação instrumental da cor ..................................................................... 62

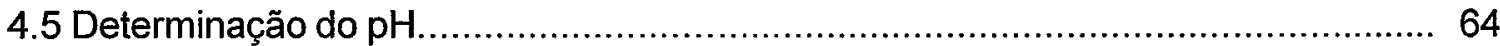

4.6 Índice de TBA

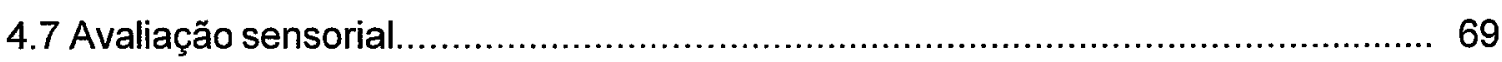

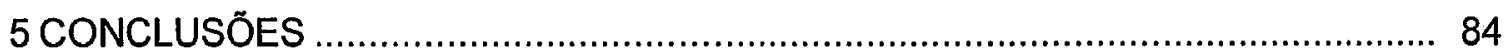

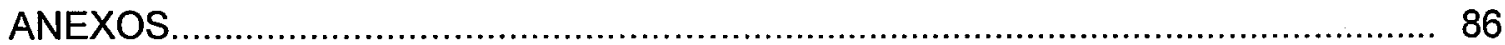

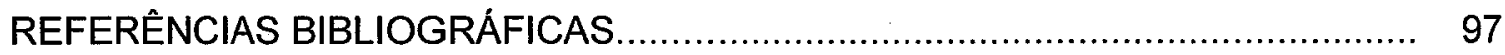




\section{LISTA DE FIGURAS}

Página

1 Evolução da população de bactérias lácticas em bistecas suínas embaladas em $100 \% \quad \mathrm{CO}_{2}$, mistura $\left(50 \% \mathrm{CO}_{2} / 50 \% \mathrm{~N}_{2}\right)$ e vácuo, durante o armazenamento $\mathrm{a} 0+3^{\circ} \mathrm{C}$

2 Evolução da população de Pseudomonas sp.em bistecas suinas embaladas em $100 \% \quad \mathrm{CO}_{2}$, mistura $\left(50 \% \mathrm{CO}_{2} / 50 \% \mathrm{~N}_{2}\right)$ e vácuo, durante o armazenamento a $0+3^{\circ} \mathrm{C}$

3 Evolução da população de Enterobactérias em bistecas suínas embaladas em $100 \% \quad \mathrm{CO}_{2}$, mistura $\left(50 \% \mathrm{CO}_{2} / 50 \% \mathrm{~N}_{2}\right)$ e vácuo, durante o armazenamento a $0+3^{\circ} \mathrm{C}$

4 Evolução da população de Psicrotróficos em bistecas suinas embaladas em $100 \% \mathrm{CO}_{2}$, mistura $\left(50 \% \mathrm{CO}_{2} / 50 \% \mathrm{~N}_{2}\right)$ e vácuo, durante o armazenamento a $0+3^{\circ} \mathrm{C}$

5 Evolução das porcentagens de $\mathrm{CO}_{2}, \mathrm{O}_{2}$ e $\mathrm{N}_{2}$ do espaço-livre dos masterpacks do tratamento com $100 \% \mathrm{CO}_{2}$ durante o estudo da vida útil da bisteca suína armazenada a $0+3^{\circ} \mathrm{C}$.

6 Evolução das porcentagens de $\mathrm{CO}_{2}, \mathrm{O}_{2}$ e $\mathrm{N}_{2}$ do espaço-livre dos masterpacks do tratamento mistura durante o estudo da vida útil da bisteca suína armazenada a $0+3^{\circ} \mathrm{C}$

7 Evolução dos valores de $\mathrm{L}^{*}$ das bistecas suínas dos tratamentos com $100 \% \mathrm{CO}_{2}$, mistura e vácuo armazenadas a $0+3^{\circ} \mathrm{C}$

8 Evolução dos valores de $a^{*}$ das bistecas suínas dos tratamentos com $100 \% \mathrm{CO}_{2}$, mistura e vácuo armazenadas a $0+3^{\circ} \mathrm{C}$.

9 Evolução dos valores de $\mathrm{b}^{*}$ das bistecas suínas dos tratamentos com $100 \% \mathrm{CO}_{2}$, mistura e vácuo armazenadas a $0+3^{\circ} \mathrm{C}$ 
10 Evolução do $\mathrm{pH}$ das bistecas suínas dos tratamentos com $100 \% \mathrm{CO}_{2}$, mistura e vácuo armazenadas a $0+3^{\circ} \mathrm{C}$

11 Evolução dos valores de TBA das bistecas suínas dos tratamentos com $100 \% \mathrm{CO}_{2}$, mistura e vácuo armazenados a $0+3^{\circ} \mathrm{C}$.

12 Evolução das notas do atributo sensorial de aparência "Cor marrom" da bisteca suína embalada em $100 \% \mathrm{CO}_{2}$, mistura e vácuo, durante estocagem a $0+3^{\circ} \mathrm{C}$ nos dias zero, $5,11,18,25$ e 32 de armazenamento.

13 Evolução das notas do atributo sensorial de aparência "Cor vermelha" da bisteca suína embalada em $100 \% \mathrm{CO}_{2}$, mistura e vácuo, durante estocagem a $0+3^{\circ} \mathrm{C}$ nos dias zero, $5,11,18,25$ e 32 de armazenamento.

14 Evolução das notas do atributo sensorial de aparência "Cor nominal do músculo" da bisteca suína embalada em $100 \% \mathrm{CO}_{2}$, mistura e vácuo, durante estocagem a $0+3^{\circ} \mathrm{C}$ nos dias zero, $5,11,18,25$ e 32 de armazenamento.... 73

15 Evolução das notas do atributo sensorial de aparência "Cor nominal do músculo" da bisteca suína embalada em $100 \% \mathrm{CO}_{2}$, mistura e vácuo, durante estocagem a $0+3^{\circ} \mathrm{C}$ nos dias zero, $5,11,18,25$ e 32 de armazenamento.... 75

16 Evolução das notas do atributo sensorial de aparência "Cor do osso" da bisteca suina embalada em $100 \% \mathrm{CO}_{2}$, mistura e vácuo, durante estocagem a $0+3^{\circ} \mathrm{C}$ nos dias zero, $5,11,18,25$ e 32 de armazenamento.

17 Evolução das notas do atributo sensorial de odor "quantidade de odor estranho" da bisteca suína embalada em $100 \% \mathrm{CO}_{2}$, mistura e vácuo, durante estocagem a $0+3^{\circ} \mathrm{C}$ nos dias zero, 5, 11, 18, 25 e 32 de armazenamento.

18 Evolução das notas do atributo sensorial de odor "Tipo de odor percebido" da bisteca suína embalada em $100 \% \mathrm{CO}_{2}$, mistura e vácuo, durante estocagem a $0+3^{\circ} \mathrm{C}$ nos dias zero, $5,11,18,25$ e 32 de armazenamento.

19 Evolução das notas do atributo sensorial "Qualidade Geral" da bisteca suína embalada em $100 \% \mathrm{CO}_{2}$, mistura e vácuo, durante estocagem a $0+3^{\circ} \mathrm{C}$ nos dias zero, 5, 11, 18, 25 e 32 de armazenamento. 


\section{LISTA DE QUADROS}

\section{Pagina}

1 Características da embalagem secundária utilizada.

2 Taxas de permeabilidade ao $\mathrm{O}_{2}$ e $\mathrm{CO}_{2}$ da embalagem primária utilizada. 


\section{LISTA DE TABELAS}

Página

1 Metodologias analíticas empregadas nas análises microbiológicas................ 36

2 Caracterização microbiológica da bisteca suína.............................................. 44

3 Efeito dos tratamentos estudados, $100 \% \mathrm{CO}_{2}$, mistura e vácuo, na inibição do desenvolvimento de Listeria monocytogenes em bisteca suína armazenada a $0+3^{\circ} \mathrm{C}$.

4 Contagem microbiológica de bactérias lácticas da bisteca suína embalada em $100 \% \mathrm{CO}_{2}$, mistura $\left(50 \% \mathrm{CO}_{2} / 50 \% \mathrm{~N}_{2}\right)$ e vácuo, durante estocagem a $0 \pm 2{ }^{\circ} \mathrm{C}$ no periodo de zero, $5,11,18.25$ e 32 dias de armazenamento

5 Contagem microbiológica de Pseudomonas da bisteca suina embalada em $100 \% \mathrm{CO}_{2}$, mistura $\left(50 \% \mathrm{CO}_{2} / 50 \% \mathrm{~N}_{2}\right)$ e vácuo, durante estocagem a $0 \pm 2{ }^{\circ} \mathrm{C}$ no período de zero, $5,11,18.25$ e 32 dias de armazenamento

6 Contagem microbiológica de enterobactérias da bisteca suina embalada em $100 \% \mathrm{CO}_{2}$, mistura $\left(50 \% \mathrm{CO}_{2} / 50 \% \mathrm{~N}_{2}\right)$ e vácuo, durante estocagem a $0+3^{\circ} \mathrm{C}$ no período de zero, $5,11,18.25$ e 32 dias de armazenamento.

7 Contagem microbiológica de psicrotróficos da bisteca suína embalada em $100 \% \mathrm{CO}_{2}$, mistura $\left(50 \% \mathrm{CO}_{2} / 50 \% \mathrm{~N}_{2}\right)$ e vácuo, durante estocagem a $0 \pm 2{ }^{\circ} \mathrm{C}$ no período de zero, $5,11,18.25$ e 32 dias de armazenamento.

8 Valores da concentração de $\mathrm{CO}_{2}, \mathrm{~N}_{2}$ e $\mathrm{O}_{2}$ das embalagens secundárias das bistecas suínas em $100 \% \mathrm{CO}_{2}$ durante a estocagem a $0+3^{\circ} \mathrm{C}$ nos dias zero, $5,11,18,25$ e 32 de armazenamento

9 Valores da concentração de $\mathrm{CO}_{2}, \mathrm{~N}_{2}$ e $\mathrm{O}_{2}$ das embalagens secundárias das bistecas suínas em mistura durante a estocagem a $0+3^{\circ} \mathrm{C}$ nos dias zero, 5 , $11,18,25$ e 32 de armazenamento 
10 Valores instrumentais da cor $L^{*}$ da bisteca suína embalada em $100 \% \mathrm{CO}_{2}$, Mistura $\left(50 \% \mathrm{CO}_{2} / 50 \% \mathrm{~N}_{2}\right)$ e vácuo, durante estocagem a $0+3^{\circ} \mathrm{C}$ nos dias zero, $5,11,18,25$ e 32 de armazenamento.

11 Valores instrumentais da cor a* da bisteca suina embalada em $100 \% \mathrm{CO}_{2}$, Mistura $\left(50 \% \mathrm{CO}_{2} / 50 \% \mathrm{~N}_{2}\right)$ e vácuo, durante estocagem a $0+3^{\circ} \mathrm{C}$ nos dias zero, $5,11,18,25$ e 32 de armazenamento.

12 Valores instrumentais da cor $b^{*}$ da bisteca suína embalada em $100 \% \mathrm{CO}_{2}$, Mistura $\left(50 \% \mathrm{CO}_{2} / 50 \% \mathrm{~N}_{2}\right)$ e vácuo, durante estocagem a $0+3^{\circ} \mathrm{C}$ nos dias zero, $5,11,18,25$ e 32 de armazenamento.

13 Valores de $\mathrm{pH}$ das bistecas suínas embaladas em $100 \% \mathrm{CO}_{2}$, mistura $\left(50 \% \mathrm{CO}_{2} / 50 \% \mathrm{~N}_{2}\right)$ e vácuo, durante estocagem a $0+3^{\circ} \mathrm{C}$ nos dias zero, 5,11 , 18,25 e 32 de armazenamento.

14 Valores de TBA das bistecas suínas embaladas em $100 \% \mathrm{CO}_{2}$, mistura $\left(50 \% \mathrm{CO}_{2} / 50 \% \mathrm{~N}_{2}\right)$ e vácuo, durante estocagem a $0+3^{\circ} \mathrm{C}$ nos dias zero, 5,11 , 18,25 e 32 de armazenamento.

15 Valores médios do atributo sensorial de aparência "Cor marrom" da bisteca suína embalada em $100 \% \mathrm{CO}_{2}$, mistura $\left(50 \% \mathrm{CO}_{2} / 50 \% \mathrm{~N}_{2}\right)$ e vácuo, durante estocagem a $0+3^{\circ} \mathrm{C}$ nos dias zero, $5,11,18,25$ e 32 de armazenamento.......

16 Valores médios do atributo sensorial de aparência "Cor vermelha" da bisteca suina embalada em $100 \% \mathrm{CO}_{2}$, mistura $\left(50 \% \mathrm{CO}_{2} / 50 \% \mathrm{~N}_{2}\right)$ e vácuo, durante estocagem a $0+3^{\circ} \mathrm{C}$ nos dias zero, $5,11,18,25$ e 32 de armazenamento.......

17 Valores médios do atributo sensorial de aparência "Cor nominal" da bisteca suína embalada em $100 \% \mathrm{CO}_{2}$, mistura $\left(50 \% \mathrm{CO}_{2} / 50 \% \mathrm{~N}_{2}\right)$ e vácuo, durante estocagem a $0+3^{\circ} \mathrm{C}$ nos dias zero, $5,11,18,25$ e 32 de armazenamento.....

18 Valores médios do atributo sensorial de aparência "Cor amarela da gordura" da bisteca suína embalada em $100 \% \mathrm{CO}_{2}$, mistura $\left(50 \% \mathrm{CO}_{2} / 50 \% \mathrm{~N}_{2}\right)$ e vácuo, durante estocagem a $0+3^{\circ} \mathrm{C}$ nos dias zero, $5,11,18,25$ e 32 de armazenamento.

19 Valores médios do atributo sensorial de aparência "Cor do osso" da bisteca suína embalada em $100 \% \mathrm{CO}_{2}$, mistura $\left(50 \% \mathrm{CO}_{2} / 50 \% \mathrm{~N}_{2}\right)$ e vácuo, durante estocagem a $0+3^{\circ} \mathrm{C}$ nos dias zero, $5,11,18,25$ e 32 de armazenamento....... 
20 Valores médios do atributo sensorial de odor, observando a presença de "Odor estranho" da bisteca suína embalada em $100 \% \mathrm{CO}_{2}$, mistura $\left(50 \% \mathrm{CO}_{2} / 50 \% \mathrm{~N}_{2}\right)$ e vácuo, durante estocagem a $0+3^{\circ} \mathrm{C}$ nos dias zero, 5,11 , 18,25 e 32 de armazenamento.

21 Valores médios do atributo sensorial de odor, caracterizando o "Tipo de odor" percebido da bisteca suína embalada em $100 \% \quad \mathrm{CO}_{2}$, mistura $\left(50 \% \mathrm{CO}_{2} / 50 \% \mathrm{~N}_{2}\right)$ e vácuo, durante estocagem a $0+3^{\circ} \mathrm{C}$ nos dias zero, 5,11 , 18,25 e 32 de armazenamento

22 Valores médios do atributo sensorial "Qualidade geral" da bisteca suína embalada em $100 \% \mathrm{CO}_{2}$, mistura $\left(50 \% \mathrm{CO}_{2} / 50 \% \mathrm{~N}_{2}\right)$ e vácuo, durante estocagem a $0+3^{\circ} \mathrm{C}$ nos dias zero, $5,11,18,25$ e 32 de armazenamento....... 


\title{
ESTUDO DA VIDA ÚTIL DA BISTECA SUÍNA EM ATMOSFERA MODIFICADA
}

\author{
Autora: KARINA GEBRIN BACHION \\ Orientadora: Prof $^{\mathrm{a}} \mathrm{Dr}^{\mathrm{a}}$. MARILIA OETTERER
}

\section{RESUMO}

A utilização de três tipos de atmosferas $\left(100 \% \mathrm{CO}_{2} ; 50 \% \mathrm{CO}_{2} / 50 \% \mathrm{~N}_{2}\right.$ e vácuo) na embalagem das bistecas suínas foram comparadas com relação às características de qualidade, que indicaram em qual tratamento as bistecas tiveram a vida útil aumentada. As bistecas suínas foram colocadas em bandejas de poliestireno $\mathrm{e}$ envoltas com poliolefínico (embalagem primária) e esse conjunto foi acondicionado no interior de uma embalagem com alta barreira ("Masterpack" - embalagem secundária) sob as atmosferas em estudo, sendo armazenados a temperaturas de $0+3^{\circ} \mathrm{C}$, durante um período de 32 dias. Periodicamente (zero, 05, 11, 18, 25 e 32 dias) foi realizada uma amostragem para avaliação microbiológica, química, física e sensorial, objetivando estimar a vida útil do produto em cada atmosfera em estudo. $O$ tratamento vácuo obteve vida útil variando entre 11 e 18 dias, visto que já apresentava sinais de deterioração avançada (contagens microbiológicas elevadas e aspectos sensoriais característicos de deterioração, como odor de sulfeto de hidrogênio) enquanto os tratamentos com gases $\left(100 \% \mathrm{CO}_{2}\right.$ e mistura) conseguiram atingir uma vida útil variando entre 18 e 25 dias, apresentando nesse periodo as caracteristicas citadas para o tratamento vácuo. $O$ estudo permitiu observar a importante ação bacteriostática do $\mathrm{CO}_{2}$ durante o estudo, resultando em baixas contagens de enterobactérias e de Pseudomonas $s p$. aos 32 dias de armazenamento. 


\title{
STUDY OF PORK LOIN CHOPS'S SHELF LIFE IN MODIFIED ATMOSPHERE
}

\author{
Author: KARINA GEBRIN BACHION \\ Adviser: Profa. Dra.MARILIA OETTERER
}

\section{SUMMARY}

The use of three types of atmospheres $\left(100 \% \mathrm{CO}_{2} ; 50 \% \mathrm{CO}_{2} / 50 \% \mathrm{~N}_{2}\right.$ and vacuum) in the packing of the pork loin chops had been compared with relation with the quality characteristics, that had indicated in which treatment the pork loin chops had the increased useful life. The pork loin chops had been placed in polystyrene trays and packed with poliolefinic (primary packing) and this set was conditioned in the interior of a packing with high barrier ("Masterpack" - secondary packing) under atmospheres in study, being stored at $0+3^{\circ} \mathrm{C}$, during a period of 32 days. Periodically (zero, $05,11,18$, 25 and 32 days) a sampling for microbiological, chemical, physical and sensorial evaluation was carried out, aiming to estimate the useful life of the product in each atmosphere in study. The vacuum treatment got useful life between 11 and 18 , since already it presented signals of advanced deterioration (high microbiological countings and characteristic sensorial aspects of deterioration, as odor of sulfeto of hydrogen) while the treatments with gases $\left(100 \% \mathrm{CO}_{2}\right.$ and mixture) had obtained to reach a useful life between 18 and 25 days, presenting in this period the characteristics cited for the vacuum treatment. The study it allowed to observe the important bacteriostatic action of $\mathrm{CO}_{2}$ during the study, resulting in low countings of enterobacteriaceae e Pseudomonas $s p$. at a time equivalent the 32 days. 


\section{INTRODUÇÃO}

Atualmente os supermercados têm mudado da embalagem tradicional de carnes frescas em filmes plásticos para exposição da carne em bandejas rígidas com revestimento de filmes plásticos permeáveis a gás. Isso protege a superfície da carne de possiveis contaminações, e o mais importante, permitindo a seleção do consumidor. Inicialmente, a decisão de compra era baseada principalmente na cor da carne e no preço. Agora múltiplos fatores, como a saúde (desejo por produtos frescos, refrigerados, livres de preservativos), conveniência, de fácil preparo, controle das porções e vida útil afetam a decisão (Standbridge \& Davies, 1998).

Os produtos cárneos têm a vida útil limitada na presença de ar devido a dois fatores principais: o efeito químico do oxigênio atmosférico e o crescimento de microrganismos deterioradores aeróbios. Estes fatores individualmente ou em associação entre si causam mudanças no odor, sabor, aroma, cor e textura conduzindo a uma total deterioração na qualidade da carne. Isso pode ser detectado através de um aumento da microbiota, descoloração, rancificação e desidratação do produto (Sarantopoulos \& Soler, 1994).

Para a maioria dos produtos cárneos, a vida útil é um fator crítico na rentabilidade e sucesso comercial do produto. A perda da qualidade e a deterioração ocorrem principalmente devido à ação proteolítica e lipolítica de bactérias aeróbias. $\mathrm{Na}$ maioria das vezes, o crescimento microbiano é o fator preponderante na manutenção da qualidade e é uma das características mais importantes do produto que devem ser considerados na avaliação de um sistema de embalagem para carne fresca (Sarantópoulos \& Soler,1994).

A embalagem com atmosfera modificada aumenta a vida útil da carne, minimiza as perdas por deterioração, abre novos mercados e provém um conveniente método de embalagem para escalas de larga distribuição, com a possibilidade 
de comercialização de produtos de alta qualidade, onde se conserva a cor, o aroma e o frescor dos alimentos. Além disso, permite a melhor apresentação do produto com maior aceitação pelo consumidor e possui baixa ou nenhuma necessidade de uso de preservativos químicos (Hood \& Mead, 1993; Sarantópoulos \& Soler, 1994).

Essas características acrescidas às alterações dos hábitos dos consumidores levaram a um aumento no interesse pelo uso da atmosfera modificada (ATM) e atmosfera controlada (AC). A atmosfera modificada é o acondicionamento do produto em materiais de alta barreira a gases, no qual o meio gasoso é mudado uma vez para retardar as taxas de respiração, reduzir o crescimento microbiológico e retardar a deterioração enzimática. A embalagem a vácuo (EV) é incluída na ATM. A atmosfera controlada (AC) é o acondicionamento do produto em materiais de barreira variável aos gases, na qual o meio gasoso foi mudado e é seletivamente controlado. Todas essas técnicas visam aumentar a vida útil (Standbridge \& Davies, 1998).

Há um futuro muito promissor para o uso da ATM, pois esta permite colocar no mercado produtos que se destacam pela sua apresentação diferenciada, além de uma melhor racionalização na distribuição e venda em função do prolongamento da vida útil e segurança que o sistema oferece.

O presente trabalho de pesquisa teve como objetivo determinar a vida útil e avaliar a eficiência de sistemas de embalagem com atmosfera modificada na preservação da qualidade da bisteca suína. 


\section{REVISÃO DE LITERATURA}

\subsection{Microbiologia da carne in natura}

A carne fresca se constitui em um rico meio de crescimento para microrganismos, visto que possui nutrientes abundantes e alta atividade de'água. Com isso, logo se torna ináceitável para o consumidor devido a tal crescimento. Contudo, é possível alterar a velocidade de deterioração, através de modificações das condições de estocagem, ou seja, do ambiente que circunda as bactérias. A modificação da atmosfera à qual os microrganismos são expostos pode alterar sua velocidade de crescimento e também a composição da microbiota, que determinará a forma de deterioração do produto (Sarantópoulos \& Soler,1994; Jeremiah, 2001).

A carga microbiológica das carnes frescas é determinada por vários fatores, tais como espécie e saúde do animal vivo, condições antes e durante $\bigcirc$ abate, resfriamento da carcaça, condições sanitárias de manuseio, tipo de embalagem e condições de distribuição e estocagem (Sarantópoulos \& Soler,1994). Em geral, carne proveniente de carcaças abatidas sob condições higiênicas apresenta contaminação inicial de $10^{3}$ a $10^{4}$ bactérias $/ \mathrm{cm}^{2}$ das quais menos de $10 \%$ e freqüentemente somente $1 \%$, são capazes de crescer a temperaturas de resfriamento (Newton \& Gill, 1978).

A deterioração microbiana resulta diretamente do crescimento e atividade metabólica daquelas bactérias melhor adaptadas a um sistema cárneo particular. A maioria dos procedimentos de processamento e preservação, estendendo-se da embalagem a vácuo á cura, promoverão uma mudança na microbiota com relação as bactérias gram-positivas. Isso pode ser exemplificado pela dominação de Lactobacillus curvatus e Lactobacillus sake em carnes curadas com desejáveis contribuições para carnes fermentadas e indesejáveis para aquelas embaladas a vácuo (Standbridge \& Davies, 1998).

Através da manipulação, refrigeração, estocagem e processamento 
(incluindo embalagem), um número de fatores influenciará seletivamente o crescimento, sobrevivência e eventual persistência de bactérias gram-positivas na carne ou produtos cárneos. Normalmente, a combinação de dois ou mais fatores determinarão a associação particular de deterioração na carne. As bactérias grampositivas geralmente são mais resistentes a condições adversas que aquelas gramnegativas, especialmente com relação ao $\mathrm{pH}$ (baixo ou alto), atividade de água reduzida, condições de nivel reduzido de oxigênio, vácuo, cura ou processo térmico (Standbridge \& Davies, 1998).

Visto que a deterioração é função da atividade microbiana, o efeito das condições de estocagem no tempo de desenvolvimento da deterioração e na forma pela qual ela se manifesta deve ser entendido em termos de fisiologia das espécies que compõem a microbiota deteriorante. Embora uma vasta gama de microrganismos mesófilos e tolerantes ao frio seja contaminante da carne, aqueles de maior importância na deterioração da carne resfriada são os seguintes psicrotróficos: Pseudomonas, Acinetobacter, Moraxella, Alteromonas putrefaciens, Brochothrix thermophacta, Lactobacillus e certos gêneros da familia Enterobacteriaceae. A contribuição de cada um desses grupos para a deterioração depende do seu número relativo e absoluto na composição da microbiota inicial e da sua taxa relativa de crescimento. Em carnes resfriadas estocadas aerobicamente, as pseudomonas predominam entre as espécies deteriorantes, embora raramente formem grande parte da microbiota inicial. Essa predominância tem sido atribuída a seu crescimento mais rápido em relação aos competidores, em uma ampla faixa de temperatura e $\mathrm{pH}$ e essa vantagem na velocidade de crescimento tende a aumentar a medida que a temperatura diminui. Porém, um número inicialmente grande de uma espécie de crescimento lento pode superar a vantagem de uma espécie de crescimento rápido presente em pequeno número. Além disso, se o número absoluto inicial das espécies deteriorantes for alto, o número de gerações necessárias para que a deterioração se torne evidente é reduzido, havendo, portanto, menos oportunidade de ser expressa a vantagem de uma velocidade alta de crescimento (Sarantópoulos \& Soler, 1994).

Bactérias potencialmente patogênicas podem estar presentes em carnes e aves, mesmo que se tenha boas condições higiênico-sanitárias durante $o$ abate $e$ evisceração dos animais. $O$ crescimento dessas bactérias potencialmente patogênicas pode ser inibido pelas bactérias deteriorantes e seus metabólitos, pelas condições de 
estocagem e pela temperatura (Sarantópoulos \& Soler, 1994).

Dois fatores da composição do produto podem precipitar a deterioração precoce: a ausência de carboidratos simples, notadamente a glicose e pH maior do que a faixa normal entre 5,4 e 5,8 (Ledward, 1985).

As bactérias aeróbias utilizam os seguintes substratos nesta ordem: Pseudomonas $s p$, glicose, amino ácidos, ácido lático; Acinetobacter $s p$, amino ácidos, ácido lático; Enterobacter, glicose, glicose 6-fosfato, amino ácidos; Microbacterium thermosphactum, glicose, glutamato. Todas as bactérias crescem na sua máxima taxa utilizando o primeiro e o segundo substrato, mas a taxa de crescimento declina quando estes se exaurem (Gill \& Newton, 1977).

A máxima estocagem em condições aeróbias é alcançada com produtos com conteúdo de glicose maior que $0,1 \%$. A máxima estocagem em condições anaeróbias é alcançada em produtos com pH menor que 5,8 e ausência de glicose (Gill \& Molin, 1991).

A concentração de glicose pode ser fator determinante do tempo necessário para o início da deterioração microbiológica da carne. As pseudomonas (aeróbias) e as enterobactérias (anaeróbias), que são causadoras de deterioração pútrida, irão utilizar preferencialmente a glicose em vez de outros substratos disponiveis na carne. Enquanto usarem a glicose como substrato nenhum componente de odor ofensivo ou desagradável será produzido. Mas à medida que a concentração de glicose se exaure e a densidade das células bacterianas aumenta na superficie, as bactérias começarão a degradar aminoácidos produzindo odor ruim dos sub-produtos como ésteres, ácidos e sulfitos (Gill, 1986; Sarantopoulos \& Soler, 1988; Gill \& Molin, 1991). A exaustão do substrato na superfície da carne não limita o crescimento bacteriano e sugere-se que a máxima densidade de células de culturas aeróbicas é determinada pela limitação de oxigênio (Gill \& Newton, 1977).

Somente alguns desses contaminantes serão capazes de crescer e eventualmente causar deterioração na carne por meios de seus atributos bioquímicos. Até o momento existem dados empíricos de pesquisas sobre formas de manter esses microrganismos distantes da carne, para reduzir sua taxa de crescimento, ou selecionar aqueles com menor potencial de deterioração. A predominância de diferentes grupos de microrganismos na carne depende das características da carne, do meio onde ela é armazenada, assim como o processo pelo qual ela irá passar 
(Garcia-Lopez et al., 1998).

Bactérias gram-negativas constituem o maior potencial deteriorante de carnes e produtos cárneos. Quando a carne fresca é armazenada refrigerada aerobicamente, membros do gênero Pseudomonas, por exemplo, expõem a taxas de crescimento rápidas e portanto a um grande potencial de deterioração. Espécies do gênero Enterobacteriaceae precisam de condições mais favoráveis do que o gênero anterior para se desenvolver e produzir metabólitos da deterioração. Dependendo dessas condições, a vida útil da carne fresca é comprometida pela deterioração antes dos sinais característicos (odores estranhos e limosidade) aparecerem. Uma extensão na vida útil é conseguida pelo impedimento do crescimento dos organismos Gramnegativos em detrimento aqueles Gram-positivos (como as bactérias ácido lácticas). Para conseguir isso, as condições do produto e o meio que o envolve (atmosfera, $a_{w}$, concentrações de sal e de nitrito, temperatura, etc) que favorecem o crescimento de bactérias gram-positivas na carne, são selecionadas (Garcia-Lopez et al., 1998).

O número de microrganismos na superfície das carnes frescas muda durante o armazenamento refrigerado seguindo um modelo típico de crescimento microbiano. A contagem de bactérias na carne geralmente está ao redor de $10^{2}-10^{5} \mathrm{UFC} / \mathrm{cm}^{2}$, mas somente em torno de $10 \%$ é capaz de iniciar o crescimento. A fase lag inicial é atribuida a adaptação microbiana as mudanças de condição (temperaturas refrigeradas e superfície de dessecação). Quando é atingido o número de $10^{7} \mathrm{UFC} / \mathrm{cm}^{2}$, são detectados os primeiros sinais de deterioração, como os odores estranhos. Um outro sinal típico de deterioração, a viscosidade bacteriana, é notado quando é atingido o número de $10^{8}$ células por $\mathrm{cm}^{2}$ (Garcia-Lopez et al., 1998).

Em um curto período, o crescimento declina e a fase estacionária é atingida. A dominância de um único grupo microbiano é devida a sua alta taxa de crescimento sob condições específicas, e essa alta taxa de crescimento é devida as vantagens do metabolismo (transformação do substrato e afinidade) ou tolerância a fatores (psicrotropismo, pH, $a_{w}$ ) (Garcia-Lopez et al., 1998).

Os microrganismos estudados neste experimento, apresentam as seguintes considerações: 


\subsubsection{Enterobactérias}

Certas espécies de Enterobacteriaceae ocorrem comumente na carne refrigerada e, esses microrganismos que são capazes de crescer no tecido adiposo e tecido muscular de alto $\mathrm{pH}(>6)$, parecem ser mais prevalentes na carne suína e de carneiro, tendo seu crescimento favorecido a temperaturas $\geq 4^{\circ} \mathrm{C}$ (Garcia-lopez et al., 1998).

Na carne suina embalada a vácuo, números substanciais de enterobactérias podem estar presentes por toda parte quando armazenada a temperaturas entre $-1,5^{\circ}$ $\mathrm{C}$ e $3^{\circ} \mathrm{C}$ (Gill \& Harrison, 1989).

\subsubsection{Microrganismos psicrotróficos aeróbios}

A contagem total de microrganismos psicrotróficos aeróbios avaliam o grau de deterioração de alimentos refrigerados (Reinbold, 1983).

Dentre os gêneros presentes neste grupo estão Pseudomonas e Listeria. A presença de um grande número de espécies de microrganismos psicrotróficos pode estar relacionada com a ocorrência de toxinfecções alimentares humanas ou com a deterioração e a perda de qualidade organoléptica dos alimentos e, com relação à quantidade de bactérias psicrotróficas necessárias em um determinado produto, para que possa haver alterações de natureza proteolítica e/ou lipolítica, cita-se que os problemas aparecem quando a contagem destes atinge $10^{7} \mathrm{UFC} / \mathrm{g}$ (Franco \& Landgraf, 1996; Sarantopoulos \& Soler, 1998).

\subsubsection{Pseudomonas sp}

O maior responsável pela deterioração microbiológica de muitos alimentos resfriados, as Pseudomonas sp., são bactérias gram negativas e têm metabolismo aeróbio. Seu crescimento é limitado pela disponibilidade de oxigênio e este efeito é maior à temperaturas mais altas e a concentrações ao redor de 1\% (Standbridge \& Davies, 1998). Segundo Sarantopoulos et al. (1996), ainda não se concluiu se o efeito 
da baixa concentração de oxigênio sobre a inibição do crescimento de Pseudomonas é sinergístico ou apenas aditivo ao de altas concentrações de $\mathrm{CO}_{2}$.

$\mathrm{Na}$ primeira fase de crescimento na carne, o metabolismo da glicose pelas pseudomonas e outras bactérias gram-negativas não eleva odores estranhos ofensivos. O crescimento é sustentado pelos carboidratos, e seu catabolismo libera uma complexa mistura de substâncias contendo ácidos graxos de curta cadeia, cetonas e álcoois, que exibem uma variedade de odores doces e de frutas. $\mathrm{Na}$ segunda fase, há o início da depleção da glicose, e os microrganismos começam a usar aminoácidos como fonte de energia, o que ocorre quando a microbiota atinge números de $10^{7}$ bactéria/ $\mathrm{cm}^{2}$ (Garcia-lopez et al., 1998).

Os voláteis responsáveis pelos odores de deterioração nessa fase são bem característicos. Os aminoácidos (como por exemplo, a Metionina) são precursores do sulfito de hidrogênio, metilsulfito e dimetilsulfito. Esses compostos são gerados pelas Pseudomonas $s p$, e Enterobacteriaceae, e produzem odores descritos como pútridos e sulfurosos (Garcia-lopez et al., 1998).

\subsubsection{Bactérias lácticas}

As bactérias lácticas realizam a fermentação láctica, onde há a produção de ácido láctico, podendo ser homolática (maior produção desse componente em relação aos demais formados, como diacetil, etanol e $\mathrm{CO}_{2}$ ) ou heterolática (proporções dos produtos formados são praticamente as mesmas), pode ainda haver a produção de ácido acético. As heterofermentadoras são importantes por produzirem substâncias responsáveis pelo aroma e sabor, tais como o acetaldeído e o diacetil (Franco \& Landgraf, 1996).

As bactérias lácticas são as isoladas com mais freqüência em carne embalada à vácuo, visto que são tolerantes ao $\mathrm{CO}_{2}$ e a baixas temperaturas. Essas bactérias sintetizam glicose, produzindo ácido acético, dentre outros, o que confere a carne um sabor e aroma de azedo (fermentado, ácido). $\mathrm{O}$ acúmulo desses ácidos ocorre principalmente durante a fase estacionária e em alguns pontos a carne já é rejeitada (Garcia-Lopez et al., 1998). 


\subsubsection{Coliformes fecais}

A pesquisa de coliformes fecais fornece com mais segurança informações sobre as condições higiênicas do produto, além de melhor indicação de eventual presença de enteropatógenos (Franco \& Landgraf, 1996).

\subsubsection{Contagem total de microrganismos mesófilos aeróbios}

A contagem total de bactérias mesófilas aeróbias em placas é comumente empregada para indicar a qualidade sanitária dos alimentos. Mesmo que os patógenos estejam ausentes e que não tenham ocorrido alterações nas condições organolépticas do alimento, um número elevado de microrganismos mesófilos aeróbios indica que o alimento é insalubre. Isso pode indicar que houve abuso durante armazenamento em relação ao binômio tempo/temperatura e, como todas as bactérias patogênicas de origem alimentar são mesófilas, uma contagem alta de mesófilos, que crescem a mesma temperatura do corpo humano, significa que houve condições para que esses patógenos se multiplicassem (Franco \& Landgraf, 1996).

\subsubsection{Staphylococcus aureus}

A presença de números elevados de Staphylococcus aureus é uma indicação de perigo potencial à saúde pública devido à enterotoxina estafilocócica, bem como à sanificação questionável, principalmente quando o processamento envolve manipulação do alimento (Franco \& Landgraf, 1996), visto que os portadores desses microrganismos (principalmente em fossas nasais) e os manipuladores de alimentos com mãos e braços que apresentam feridas infectadas com $\mathrm{S}$. aureus são importantes fontes de contaminação no alimento (Smith et al., 1983). 


\subsubsection{Salmonella sp.}

A Salmonella sp. não é considerada como um patógeno psicrotrófico, mas o seu crescimento e sobrevivência são bem conhecidos por serem dependentes, além da temperatura, de numerosos fatores como o $\mathrm{pH}$, atmosfera e microbiota competitiva. De fato, a inabilidade da Salmonella em competir com sucesso com bactérias lácticas tem sido relatada. Em experimentos feitos com aves (peito e coxa) inoculadas com Salmonella e armazenadas em várias atmosferas (vácuo, $100 \% \mathrm{CO}_{2}, 100 \% \mathrm{~N}_{2}$ e $20 \%$ $\mathrm{CO}_{2} / 80 \%$ ar), esta bactéria sobreviveu, mas não cresceu a $3^{\circ} \mathrm{C}$. $\mathrm{A} 10^{\circ} \mathrm{C}$, os números de Salmonella cresceram rapidamente em amostras com $100 \% \mathrm{~N}_{2}$ ou com $\mathrm{CO}_{2}$ lar $(20: 80)$ e para uma extensão menor em amostras embaladas a vácuo. Em amostras armazenadas com concentrações abaixo de $100 \%$ de $\mathrm{CO}_{2}$, os números de Salmonella decresceram após 12 dias armazenados em peito de frango, enquanto que em coxa de frango eles permaneceram nos niveis iniciais. Nenhum problema desses pode ser atribuído ao $\mathrm{pH}$ mais alto da coxa de frango, que poderia ser considerado como um tipo de músculo DFD. O tipo de músculo (coxa ou peito) não afetou significativamente a sobrevivência a $3^{\circ} \mathrm{C}$ ou a taxa de crescimento a $10^{\circ} \mathrm{C}$ de Salmonella em outras atmosferas utilizadas (Garcia de Fernando et al., 1995).

Este experimento demonstra que, embora a Salmonella não possa crescer em ATM a temperaturas refrigeradas $\left(3^{\circ} \mathrm{C}\right)$, isso pode constituir um risco quando um abuso de temperatura é apresentado em cadeia comercial (Garcia de Fernando et al., 1995).

\subsubsection{Listeria monocytogenes}

Quanto a Listeria monocytogenes, produtos cárneos são fontes potenciais porque essa bactéria é freqüentemente presente nestes alimentos e pode sobreviver e se multiplicar no armazenamento em condições normais de temperatura e de ambiente. A temperaturas de refrigeração, o crescimento de $L$. monocytogenes é lento. $\mathrm{O}$ crescimento é considerado possivel a $1^{\circ} \mathrm{C}$ embora também tenha sido relatado a $1,5^{\circ} \mathrm{C}$ (Hart et al., 1991; Mano et al., 1995). 
O crescimento de $L$. monocytogenes em carne embalada em ATM tem sido o foco de inúmeros e controversos estudos. Esta bactéria não é fortemente inibida pela embalagem a vácuo ou em atmosfera enriquecida com $\mathrm{CO}_{2}$ e pode predominar em carne refrigerada ou produtos cárneos embalados deste modo (Mano et al., 1995). Isso é baseado no fato de que, segundo este autor, a $L$. monocytogenes cresceu mais rápido do que outra microbiota presente em frango cru ou pré-cozido, quando embalado em ATM. No entanto, outros autores têm mostrado que embalagem em ATM inibe o crescimento de L. monocytogenes (Wimpfhimer et al., 1990; Hart et al., 1991).

\subsection{Alterações nas características físico-químicas da carne in natura}

\subsubsection{Cor da carne in natura}

No ponto de venda, a aparência da embalagem de varejo e a cor da carne são importantes e são influenciadas pela permeabilidade do filme, na dada temperatura de exposição; tempo de oxigenação do pigmento da carne (blooming); histórico dos tratamentos pré-acondicionamento; o tipo, potência e intensidade da iluminação; tempo de exposição à luz; tempo de permanência em exposição; temperatura na superfície da carne na exposição; localização da bandeja no expositor e freqüência e duração dos ciclos de descongelamento do expositor (Kropf, 1980).

A cor das carnes frescas é o índice de frescor e qualidade mais óbvio para o consumidor, influenciando muito sua decisão de compra. É determinada pela proporção relativa das três formas da mioglobina: mioglobina reduzida (Mb), de coloração vermelho púrpura; mioglobina oxigenada ou oximioglobina $\left(\mathrm{O}_{2} \mathrm{Mb}\right)$, de coloração vermelho brilhante, e mioglobina oxidada ou metamioglobina (MetMb), de coloração marrom (Gill, 1996; Sarantopoulos et al., 1996).

O ciclo da cor em carnes frescas é reversível e dinâmico, até que a carne seja aquecida à temperatura de desnaturação do pigmento (Fox, 1966). A interconversão das três formas da mioglobina é evidente na carne fresca exposta ao ar. Sua superfície fica vermelha brilhante, devido à formação de $\mathrm{O}_{2} \mathrm{Mb}$ (blooming). Alguns milímetros abaixo da superfície, onde a pressão de oxigênio é pequena, desenvolve-se uma camada marrom-acinzentada, devido a formação de MetMb. 
Durante a estocagem, essa camada de MetMb aumenta gradualmente, em direção a superficie, à medida que o oxigênio é consumido na carne. Como conseqüência, a aparência da superfície muda para uma coloração marrom, de carne velha, pois a camada vermelha $\left(\mathrm{O}_{2} \mathrm{Mb}\right)$ superficial é translúcida. Abaixo da camada de MetMb, em condições anaeróbicas, existe uma região de coloração vermeho-púrpura, característica da Mb reduzida (Sarantopoulos \& Pizzinato, 1990; Zhao et al., 1994).

Outro exemplo de interconversão das três formas da mioglobina é visto na embalagem à vácuo, onde se tem um ambiente anaeróbio ao redor do produto. Quando a carne fresca está em ambiente anaeróbio, $\mathrm{a}_{2} \mathrm{Mb}$ transforma-se em $\mathrm{Mb}$, de coloração arroxeada. Após abertura da embalagem e exposição da carne ao ar ambiente, a $\mathrm{Mb}$ se transforma em $\mathrm{O}_{2} \mathrm{Mb}$, de coloração vermelho brilhante. Contudo, caso o residual de oxigênio na embalagem não seja baixo o suficiente, resultando em baixa pressão parcial de oxigênio ao redor da carne, a $\mathrm{O}_{2} \mathrm{Mb}$ poderá oxidar-se a MetMb, de coloração marrom que não mais se reverte a $\mathrm{O}_{2} \mathrm{Mb}$ (Taylor, 1982; Hermansen, 1983).

A dinâmica da interconversão e das proporções relativas de mioglobina, oximioglobina e metamioglobina controla a cor da carne. A mioglobina reduzida que é púrpura $(\mathrm{Mb})$ na presença de oxigênio (pressão de $\mathrm{O}_{2}>40$ torr) é convertida a oximioglobina $\left(\mathrm{O}_{2} \mathrm{Mb}\right)$, que é a familiar cor vermelha brilhante (bloom) das embalagens de carne nos balcões expositores das lojas. As pressões de oxigênio entre 1 a 1.4 torr, ocorre a oxidação a metamioglobina (MetMb) de coloração marrom (Rizvi, 1981).

$\mathrm{Na}$ reação de oxigenação, chamada de blooming, a Mb se transforma em $\mathrm{O}_{2} \mathrm{Mb}$ e a variação de éntalpia $(\Delta \mathrm{H})$ indica uma reação exotérmica e espontânea. Por isso esta reação ocorre espontaneamente na superficie da carne quando ela é exposta ao ar. Outra característica da reação de oxigenação é seu caráter reversível, ou seja, quando a pressão parcial do oxigênio diminui, a $\mathrm{O}_{2} \mathrm{Mb}$ se reverte a $\mathrm{Mb}$ (Young et al., 1999).

A oximioglobina é estável a pressões parciais de oxigênio maiores que 25 $\mathrm{mmHg}$, sua constante de dissociação é da ordem de $2,1 \times 10^{-6}$ (Govindarajan, 1973). Em pressões parciais mais baixas que $25 \mathrm{mmHg}$, se converte a deoximioglobina, que é menos estável, exceto em pressões muito reduzidas, menores que 1,4 $\mathrm{mmHg}$ (Kropf et al., 1985). A metamioglobina forma-se mais rapidamente a baixas concentrações de oxigênio, porque a deoximioglobina é mais suscetivel à oxidação que a oximioglobina 
(Fox, 1966). Assim, com respeito à cor da carne, a reação de oxigenação é desejável não só devido à formação de oximioglobina, mas também, pelo fato de aumentar a estabilidade do pigmento quanto à oxidação (Sarantopoulos \& Soler, 1988).

Mesmo se a formação de metamioglobina é prevenida pela rigorosa exclusão de oxigênio durante a estocagem, a perda da capacidade de redução de metamioglobina, reduz a habilidade do músculo de resistir à descoloração, quando exposto ao ar (Gill \& Molin, 1991).

Um grande aumento na concentração de metamioglobina, também ocorre durante a fase de crescimento logaritimico de microrganismos na superficie da carne, provavelmente porque tal crescimento acarreta um baixo potencial de oxi-redução (Butler et al., 1953).

Infelizmente, a cor da carne fresca tem a vida limitada e a descoloração da superficie que ocorre durante $o$ armazenamento refrigerado é considerado um sinal de qualidade inferior e de deterioração do produto. As três propriedades sensoriais pelas quais os consumidores mais rapidamente julgam a qualidade da carne são aparência, textura e flavor. No ponto de venda, a cor e a estabilidade da cor são os atributos mais importantes da qualidade da carne e várias tentativas foram feitas para satisfazer as expectativas do consumidor de que uma coloração atrativa e vermelho brilhante indica uma longa vida útil e boa caracteristica de qualidade (O'Sullivan et al., 2003).

O uso da escala estruturada tem sido o método de avaliação sensorial mais usado nos estudos da coloração da carne. No entanto, a escala não estruturada pode facilitar um maior grau de discriminação entre as amostras. Este método de escala não restringe os julgadores em categorias, seguindo então o uso livremente da escala e escala diferente usada pelos julgadores pode ser corrigida pelo uso de dados multivariáveis de técnicas analíticas (O'Sullivan et al., 2003).

O'Sullivan et al. (2002) usaram escala de linha não estruturada para avaliar a estabilidade da cor de bistecas suínas de 4 tratamentos dietéticos por uma equipe sensorial treinada sob padrões comerciais de venda com maior grau de discriminação que os métodos instrumentais (Hunter $L^{*}, a^{*}, b^{*}$ ) medidos pelo colorímetro Minolta. 


\subsubsection{Odor e aroma}

O desenvolvimento de odor ruim ou rancidez oxidativa é reconhecidamente um sério problema de perda de qualidade e rejeição pelo consumidor (Gray et al., 1996).

\subsubsection{Indice de rancificação (valores de TBA)}

A deterioração da gordura é conhecida como rancificação. Existem dois tipos de rancificação: a hidrolitica, geralmente de origem enzimática podendo ser causada por microrganismos, e a oxidativa, que não depende da ação de microrganismos. As Pseudomonas sp. são exemplos de bactérias que causam rancificação. A rancificação oxidativa produz substâncias com aroma pronunciado e desagradável devido à decomposição dos hidroperóxidos em compostos carbonilicos (misturas de cetonas e aldeídos saturados e insaturados). $\mathrm{Na}$ rancificação hidrolítica ocorre a liberação de ácidos graxos das moléculas de triglicerídeos, sendo que os de cadeia curta, como o butirico, capróico e caprílico, causam odores estranhos nos alimentos nos quais estão presentes (Franco \& Landgraf, 1996).

Os principais microrganismos lipolíticos causadores da deterioração da gordura na carne são, além das pseudomonas e outros Gram-negativos, Bacillus, leveduras e bolores. Esses mesmos microrganismos também são ativos na degradação oxidativa de ácidos graxos (Franco \& Landgraf, 1996).

A susceptibilidade às mudanças oxidativas e ao desenvolvimento da rancidez é determinada pela composição de lipídios na carne em oposição à quantidade presente (Gill \& Molin, 1991).

A oxidação de lipídios ocorre devido à auto-oxidação de ácidos graxos insaturados. Estas reações são catalisadas pelos mesmos fatores que oxidam o pigmento mioglobina em metamioglobina, porém, ocorrem em velocidades menores que as reações de descoloração ou as de crescimento microbiano, assim, não são fator determinante da vida útil da carne (Zhao et al., 1994).

Geralmente pode-se esperar que a restrição do acesso ao oxigênio durante acondicionamento resulte em retardo da oxidação de pigmentos e lipídios, mas o grau 
de restrição requerido para prevenir oxidação em diferentes produtos não foi bem definido e merece investigações posteriores, pela significância na manutenção da qualidade e estabilidade da estocagem de alguns produtos cárneos (Jakobsen \& Bertelsen, 2000).

\subsubsection{Exsudação}

Toda carne fresca refrigerada perderá líquido exsudado durante a estocagem. A importância da exsudação é econômica já que a carne é vendida por peso. A quantidade de exsudado varia com a composição do músculo, condições de processamento da carcaça, tamanho dos pedaços de carne, temperatura de estocagem e pressão mecânica devido ao empilhamento excessivo. Entretanto para qualquer conjunto de circunstâncias, o total de exsudado alcançará seu máximo entre 1 e 2 semanas (Gill \& Molin, 1991).

\subsection{Utilização de Atmosfera Modificada (ATM) como sistema de preservação de carnes e produtos cárneos}

Há duas maneiras comumente usadas pela indústria alimentícia para modificar a atmosfera gasosa no interior de um produto embalado: a primeira e mais simples é a aplicação de vácuo; a segunda, a introdução de gases desejados, após evacuação e antes do fechamento da embalagem. A embalagem a vácuo consiste em envolver o produto em um filme de baixa permeabilidade ao oxigênio, com remoção do ar da embalagem, e aplicação de uma selagem hermética. A embalagem a gás é uma extensão deste processo, envolvendo a remoção do ar da embalagem e sua substituição por gases específicos, um único gás ou uma combinação deles (Church, 1994).

A composição normal do ar é $21 \%$ de oxigênio, $78 \%$ de nitrogênio e menos que $0,1 \%$ de dióxido de carbono. A modificação da atmosfera no interior da embalagem por meio da redução dos teores de oxigênio e aumento nos niveis de dióxido de carbono/nitrogênio tem se mostrado eficaz para estender a vida útil dos 
alimentos pereciveis, como carne, peixe e seus produtos, a temperaturas de refrigeração, pois restringe e/ou inibe o crescimento de organismos deterioradores aeróbios (Parry, 1993).

No entanto, para que ocorra um aumento efetivo da vida útil do produto, em condições seguras, a aplicação dessa tecnologia depende da otimização do sistema, que está associado a cinco parâmetros críticos (Hotchkiss, 1988; Lioutas, 1988; Sarantópoulos \& Soler, 1988; Day, 1992):

1. Natureza e qualidade inicial do produto;

2. Adequação da mistura gasosa em relação ao produto e à embalagem;

3. Controle rigoroso da temperatura de estocagem, distribuição e comercialização;

4. Propriedades da embalagem;

5. Sistema e equipamento de acondicionamento eficientes.

\subsubsection{Natureza e qualidade inicial do produto}

A qualidade inicial do produto, em termos microbiológicos e organolépticos, deve ser imprescindivelmente boa, pois as atmosferas modificadas não melhoram a qualidade inicial, apenas a mantêm por períodos mais prolongados. Se a contaminação microbiológica inicial for alta, a ação do $\mathrm{CO}_{2}$ é menor, podendo até ser completamente ineficaz. Desta forma, são muito importantes as boas práticas sanitárias durante a fabricação ou manuseio do produto (Day, 1992).

A velocidade de crescimento dos microrganismos, assim como a composição da microbiota que determinará a forma de deterioração do produto, podem ser alterados de acordo com a modificação da atmosfera a qual esses microrganismos sejam expostos. Dependendo do tipo de microrganismo presente, os odores e sabores estranhos desenvolvem-se 2 a 3 semanas após a população máxima de $10^{8} \mathrm{UFC} / \mathrm{cm}^{2}$ ser alcançada (Egan et al., 1982). Isto depende em parte da composição da microbiota e do número de microrganismos inicialmente presentes que são capazes de crescer em ATM (Newton et al., 1979). Esse é um ponto crítico de controle, principalmente no caso dos produtos fatiados, para os quais a etapa de corte representa uma fonte de contaminação microbiológica (Molin, 2000).

Os processos de deterioração são função, preponderantemente da atividade 
microbiana. Deste modo, o crescimento microbiano é, freqüentemente, o fator limitante na manutenção da qualidade. O ponto a partir do qual a deterioração torna-se evidente aos sentidos humanos depende da natureza do substrato, do tipo de organismo presente e do número alcançado por cada tipo de microrganismo. Entretanto é possível alterar a velocidade de desenvolvimento da deterioração através da modificação das condições de estocagem, ou seja, do meio ambiente ao qual a bactéria é exposta (Gill, 1986).

Quando as bactérias passam da fase de adaptação para a fase de crescimento exponencial, o efeito do $\mathrm{CO}_{2}$ é notadamente reduzido. Felizmente, muitas das bactérias que causam a deterioração de alimentos pereciveis, como Pseudomonas e Acinetobacter/ Moraxella, Micrococcus e Bacillus, são inibidas por baixas concentrações de gás carbônico. Outros microrganismos como os Lactobacillus são mais resistentes. Assim, verifica-se uma inibição seletiva de microrganismos deterioradores Gram-negativos, com alteração da população que fica constituida predominantemente por espécies Gram-positivas. Tal fato tem grande interesse tecnológico, pois é selecionada uma microbiota de menor potencial de deterioração (Enfors et al., 1979; Sarantópoulos et al., 1996).

\subsubsection{Adequação da mistura gasosa em relação ao produto e à embalagem}

A escolha da mistura gasosa usada é influenciada pela microbiota capaz de crescer no produto, pela sensibilidade do produto ao $\mathrm{O}_{2}$ e $\mathrm{CO}_{2}$, e estabilização do pigmento requerido. Os gases normalmente usados em embalagens com ATM são aqueles encontrados na atmosfera: $\mathrm{O}_{2}, \mathrm{~N}_{2}$ e $\mathrm{CO}_{2}$ (Parry, 1993), e cada um tem um papel específico na extensão da vida útil e manutenção de uma boa aparência do produto (Luno et al., 1998).

\subsubsection{Oxigênio $\left(\mathrm{O}_{2}\right)$}

Os alimentos deterioram devido a fatores físicos, químicos e microbiológicos. $\mathrm{O} \mathrm{O}_{2}$ é provavelmente o gás mais importante neste contexto, sendo usado 
metabolicamente pelos microrganismos deterioradores aeróbicos e faz parte de algumas reações enzimáticas em alimentos, incluindo a oxigenação da mioglobina (oximioglobina) na carne, a oxidação da gordura e de componentes sensíveis como as vitaminas e alteração do flavour (sabor e aroma). Por isso, na embalagem com ATM, o $\mathrm{O}_{2}$ geralmente é excluido ou reduzido a niveis tão baixos quanto possiveis. Exceção a esta regra, quando o $\mathrm{O}_{2}$ é necessário para manter a cor, como na carne vermelha (Parry, 1993), pois a oximioglobina confere a coloração vermelho-brilhante da carne crua (O'Grady et al., 2000).

No entanto, mudanças na concentração parcial de $\mathrm{O}_{2}$ revertem rapidamente este estado de oxigenação: a baixas concentrações de $\mathrm{O}_{2}$ a carne adquire coloração mais escura devido a cor roxa da mioglobina desoxigenada, e essa, a baixas concentrações de $\mathrm{O}_{2}$ pode formar a metamioglobina e o pigmento torna-se marrom, decorrendo em um produto visualmente inaceitável (Molin, 2000).

O oxigênio está presente na atmosfera a nivel de $21 \%$ e, diferentemente do nitrogênio, é um gás reativo. Sua presença nas misturas gasosas é uma questão controvertida (Sarantopoulos et al., 1996).

A cor é provavelmente o único grande fator aparente que determina se a carne cortada será comprada. Alguns problemas de cor têm sido encontrados quando lombos suínos embalados em ATM são cortados em costelas. Elas rapidamente podem tornar-se cinza ou verde e, conseqüentemente, não vendáveis. Adicionando $\mathrm{O}_{2}$ nesta atmosfera para melhorar a aparência externa do lombo também pode resultar em descoloração do corte da costela. $\mathrm{O}_{2}$ não é desejável na mistura gasosa por longo período de armazenamento da carne suína. A concentração do $\mathrm{O}_{2}$ na embalagem em ATM comercial freqüentemente é muito elevada, o que limita a vida do produto (Sorheim et al., 1996).

A utilização de filmes de baixa permeabilidade a gases e ao vapor d'água, a estocagem a baixas temperaturas, a não exposição prolongada do produto à luz e o acondicionamento a vácuo ou com ATM ajudam a minimizar este problema (Djenane et al., 2001). 


\subsubsection{Nitrogênio $\left(N_{2}\right)$}

O nitrogênio é um gás quimicamente inerte, com baixa solubilidade tanto em meio aquoso como lipidico. $\mathrm{O} \mathrm{N}_{2}$ é usado para substituir o $\mathrm{O}_{2}$, assim como retardar a rancidez oxidativa, minimizar problemas de coloração, sabor e odor estranhos e inibir o crescimento de microrganismos aeróbios. Devido a sua baixa solubilidade e menor permeabilidade através da embalagem em relação ao $\mathrm{O}_{2}$ e $\mathrm{CO}_{2}$, é usado como um gás de enchimento para prevenir o colapso da embalagem, que pode ser um problema em atmosferas contendo altas concentrações de $\mathrm{CO}_{2} \mathrm{O}$ nitrogênio pode ser usado para produzir um efeito "travesseiro", que reduz a possibilidade de furos nas embalagens e permite maior facilidade de separação dos fatiados (Church, 1994; Gill, 1996).

\subsubsection{Dióxido de Carbono $\left(\mathrm{CO}_{2}\right)$}

$\mathrm{O} \mathrm{CO}_{2}$ é solúvel tanto em meio aquoso como lipídico e é principalmente responsável pelo efeito bacteriostático e fungistático. $\mathrm{A}$ ação do $\mathrm{CO}_{2}$ sobre a microbiota tem sido atribuida à redução de $\mathrm{pH}$, devido à dissolução do $\mathrm{CO}_{2}$ no meio, às alterações da permeabilidade celular bacteriana (incluindo efeitos na captura e absorção de nutrientes) e à inibição enzimática (ou diminuição da velocidade das reações enzimáticas), resultando no prolongamento da fase de adaptação e o aumento do tempo de geração dos microrganismos, o que resulta em uma velocidade de crescimento diminuída, além de uma mudança na microbiota, levando à predominância de microrganismos de menor potencial de deterioração (King \& Nagel,1975; Sarantópoulos \& Soler,1994). Além disso, pode também ser devido às alterações físico-quimicas das proteínas (Farber, 1991). Este efeito bacteriostático é influenciado pela concentração de $\mathrm{CO}_{2}$, carga microbiana inicial, que deve ser baixa, temperatura de estocagem e tipo de produto a ser embalado, gerando uma maior efetividade da mistura gasosa no prolongamento da vida útil do alimento (Church, 1994; Molin, 2000).

No geral, altas concentrações de $\mathrm{CO}_{2}$, são melhores em termos de inibição de microrganismos deterioradores. Uma longa vida útil pode ser conseguida com 100\% $\mathrm{CO}_{2}$. No entanto, um produto pode sofrer mudanças químicas que são prejudiciais a qualidade da carne. A prevalência de um crescimento lento de bactérias lácticas é 
responsável pela vida útil estendida. No entanto, dependendo de vários fatores $(\mathrm{pH}$, temperatura de estocagem, número inicial, material de embalagem, etc), as enterobactérias podem crescer e causar deterioração. De acordo com vários autores (Ordonez et al., 1991; Dainty \& Mackey, 1992), Enterobacteriaceae e Pseudomonas sp são as espécies mais prevalentes em ATM do que em carne embalada a vácuo, especialmente a suína, sendo seu crescimento favorecido pela estocagem a $5^{\circ} \mathrm{C} \mathrm{e}$ pelo acondicionamento em ar. Os efeitos inibitórios do $\mathrm{CO}_{2}$ são potencializados pela limitação da disponibilidade de $\mathrm{O}_{2}$ em atmosferas modificadas contendo baixa concentração de $\mathrm{O}_{2}$ (Gill, 1992).

De acordo com Sorheim et al. (1996), alguns experimentos indicaram também um efeito residual marcante na contínua inibição do crescimento em carne suína posteriormente estocada em ar ambiente e o crescimento da microbiota deterioradora de lombo suíno foi efetivamente inibida durante o armazenamento em uma atmosfera contendo $25 \%$ de $\mathrm{CO}_{2}$, porém, segundo Mcmullen \& Stiles (1991), esse valor deve ser de $40 \%$.

No entanto, a concentração de $\mathrm{CO}_{2}$ nas embalagens pode também causar alterações na cor e no sabor dos produtos. Além disso, atmosferas com altas concentrações de $\mathrm{CO}_{2}$ podem acarretar o colapso da embalagem, pois o $\mathrm{CO}_{2}$ permeia o material de embalagem mais rapidamente do que $\circ \mathrm{O}_{2}$ e $\mathrm{N}_{2}$ e é solúvel na água e na gordura do alimento, o que leva a um decréscimo no volume gasoso. A concentração de $\mathrm{CO}_{2}$ a ser escolhida é, portanto, mais dependente do produto a ser acondicionado e do tamanho e características de barreira da embalagem que do efeito inibitório sobre os microrganismos (Molin, 2000).

A quantidade de $\mathrm{CO}_{2}$ dissolvido na carne e o volume de espaço-livre são fatores importantes e são dependentes, além do teor de umidade e de gordura, do $\mathrm{pH}$ e área superficial da carne, bem como da proporção de volume de gás para o peso da carne dentro da embalagem (Gill, 1988). Além disso, os níveis gasosos de uma mistura atmosférica nunca são estáticos e mudam constantemente, não somente devido a solubilidade do $\mathrm{CO}_{2}$, mas também devido à respiração muscular, metabolismo microbiano, dissolução do gás no interior da carne, difusão através de filmes barreiras e efeitos da temperatura. A magnitude de cada mudança será maior em embalagem com menor proporção do espaço-livre para o volume da carne, que deve ser de 2:1 
(Molin, 2000). Na Dinamarca, a relação é de 3:1 e em outros paises essa relação cai para 1:1 (Hermansen, 1983).

A combinação de gases utilizados depende de muitos fatores, como o tipo de produto, material de embalagem e temperatura de armazenamento. Com relação ao produto, o conteúdo de gordura, umidade, características microbiológicas e estabilização da cor (para carnes vermelhas) são fatores criticos (Parry, 1993).

No geral, a maioria dos produtos cárneos processados requerem atmosferas contendo altas concentrações de $\mathrm{CO}_{2}$, isto é, maiores que $20 \%$, com o restante sendo $\mathrm{N}_{2}$, e ausência de $\mathrm{O}_{2}$, ou seja, menor que $0,1 \%$. Entretanto, na prática pode ser difícil alcançar niveis de $\mathrm{O}_{2}$ residual tão baixos quanto este, pois são altamente dependentes das características do produto, das técnicas de embalagem e do método de remoção do ar e introdução do gás (Hotchkiss, 1988).

No entanto, qualquer que seja a mistura, ela deve ser totalmente testada e conter gases cujo uso é permitido pela legislação. Também é importante definir o nivel de evacuação e a quantidade de gás injetado para repor o ar retirado (Hermansen, 1983).

\subsubsection{Controle rigoroso da temperatura de estocagem, distribuição e comercialização}

A aplicação da tecnologia de embalagens com ATM não substitui a necessidade de refrigeração, durante o preparo, distribuição e comercialização do produto (Hotchkiss, 1988; Day, 1992).

Quanto maior a temperatura, maior a taxa de crescimento microbiano e de mudanças bioquímicas, pois a maioria dos microrganismos multiplica-se rapidamente a temperaturas entre 20 e $30^{\circ} \mathrm{C}$ e têm o crescimento restringido por baixas temperaturas. No entanto, existem microrganismos deterioradores psicrotróficos (que crescem e causam deterioração dos alimentos mesmo em temperaturas de refrigeração). Neste caso, é importante a ação de atmosferas modificas para retardar a deterioração, contudo ela não substitui a estocagem refrigerada $\mathrm{e}, \mathrm{o}$ controle rígido da temperatura de estocagem, na faixa de 1 a $3^{\circ} \mathrm{C}$, é obrigatório para a efetividade desse sistema de preservação, pois em temperaturas mais elevadas é menor a ação do $\mathrm{CO}_{2}$ como 
agente retardador da deterioração microbiológica (Sarantópoulos, 1991; Sarantópoulos et al., 1996; Molin, 2000).

A solubilidade do $\mathrm{CO}_{2}$ na umidade do produto decresce com o aumento da temperatura, o que é esperado, pois está relacionado com o comportamento geral dos gases em soluções aquosas. Por isso, quanto mais baixa a temperatura, mais eficaz é - gás carbônico como inibidor de microrganismos deterioradores, apresentando grande efeito entre 0 e $5^{\circ} \mathrm{C}$ (Sarantópoulos et al., 1996).

A permeabilidade a gases das embalagens plásticas também é função da temperatura e geralmente aumenta com a elevação da temperatura. Portanto, a especificação da barreira a gases da embalagem depende da temperatura de estocagem e distribuição (Sarantópoulos et al., 1996).

A temperatura de estocagem acima de $0^{\circ} \mathrm{C}$ aumenta a permeabilidade do material de embalagem, o que influencia as trocas gasosas entre o interior da embalagem e o ambiente, isto pode produzir considerável escurecimento depois de prolongada estocagem. $O$ efeito inibitório do dióxido de carbono aumenta progressivamente com o decréscimo da temperatura de estocagem, devido ao aumento da solubilidade do dióxido de carbono na carne (Ogilvy \& Ayres, 1951; Gill, 1996).

Altas concentrações de $\mathrm{CO}_{2}$ têm efeito inibitório sobre Salmonella spp., Staphylococcus aureus, Escherichia coli e Bacillus cereus. Vários estudos constataram que Pseudomonas spp. pode crescer em atmosferas de $1-2 \%$ de $\mathrm{O}_{2}$, mesmo na presença de elevados níveis de $\mathrm{CO}_{2}$. Um ambiente completamente anaeróbio não será produzido se $\mathrm{O}_{2}$ puder permear através do filme da embalagem (Church, 1993). Os estudos sobre Listeria monocytogenes, Aeromonas hidrophyla e Yersinia enterocolitica ainda estão incompletos. O controle estrito da temperatura é necessário para prevenir o crescimento destes patógenos (Sarantópoulos et al., 1996).

Estudos preliminares têm mostrado que costelas suinas frescas em embalagens unitárias de consumo em $20 \%$ de $\mathrm{CO}_{2}$ sem $\mathrm{O}_{2}$, e em $40 \%$ de $\mathrm{CO}_{2}$ com ou sem $\mathrm{O}_{2}$ e armazenada a $4^{\circ} \mathrm{C}$ tiveram uma vida útil em torno de 6 semanas (ManuTawiah et al., 1993). Segundo Mcmullen \& Stiles (1991), a temperatura mínima de armazenamento da carne fresca sem congelamento é de aproximadamente $-1,5^{\circ} \mathrm{C}$. $\mathrm{O}$ armazenamento em ATM a temperaturas próximas $a-1^{\circ} \mathrm{C}$ marcadamente estende a vida útil da carne fresca. Cortes de carne suína armazenados em uma atmosfera de 
$100 \%$ de $\mathrm{CO}_{2}$ a $-1,5^{\circ} \mathrm{C}$ têm uma vida útil de 12 semanas, contanto que $\circ \mathrm{O}_{2}$ seja mantido em concentrações muito reduzidas durante todo o armazenamento. Contudo, este mesmo autor cita ainda que uma mistura de gases de $30 \%$ de $\mathrm{CO}_{2}$ e $70 \%$ de $\mathrm{N}_{2}$ foi tão efetiva na exíensão do armazenamento quanto $100 \%$ de $\mathrm{CO}_{2}$ quando costelas suínas foram armazenadas a $2^{\circ} \mathrm{C}$.

A estocagem da carne a baixas temperaturas, menores que $5^{\circ} \mathrm{C}$, retarda 0 crescimento de todas as bactérias e estende a vida útil. No entanto, a composição da microbiota será afetada se houver um incremento na temperatura acima da temperatura mínima de crescimento de mesófilos, permitindo que estes organismos comecem a crescer. Adicionalmente, os psicrotróficos, que são inibidos pelo $\mathrm{pH}$ e/ou concentrações de ácido lático à baixa temperatura, estarão aptos a crescer com o incremento da temperatura (Jeremiah \& Gibson, 2001).

\subsubsection{Propriedades da embalagem}

Os efeitos do acondicionamento sobre a vida útil são bastante relacionados à permeabilidade a gases e ao vapor d'água do material de embalagem. Para prover vida útil mais longa, as taxas de transmissão de vapor d'água e de gases devem ser baixas porque a permeabilidade a gases do material de embalagem é importante determinante das mudanças no espectro de cor e na manutenção da qualidade (Stiles, 1991). Todos os plásticos são permeáveis a gases em algum grau (Hunt \& Kropf, 1987; Jeremiah \& Gibson, 2001).

A quantidade de gás permeada através do filme plástico varia com as diferenças na pressão parcial nos dois lados do filme, com o tipo e a espessura das camadas de filme e a temperatura do plástico. Filmes com permeabilidade mínima ao oxigênio menor que $100 \mathrm{~mL} /\left(\mathrm{m}^{2} / 24 \mathrm{~h}\right)$ atm a $23^{\circ} \mathrm{C}$ e $0 \%$ UR, os quais têm desempenho comparável aos filmes metalizados, aumentam a vida útil entre 10 e 15\% (Gill \& Molin, 1991; Stiles, 1991; Bell et al.,1996). Kraft \& Ayres (1952) afirmaram que somente os filmes com taxa de permeabilidade ao oxigênio menor que $10 \mathrm{~mL} / \mathrm{(m}^{2} /$ $24 \mathrm{~h}$ ) atm a $23^{\circ} \mathrm{C}$ e $0 \%$ UR podem ser usados em acondicionamento preservativo, pois retém $\mathrm{CO}_{2}$ no interior da embalagem. A habilidade do material de embalagem de reter $\mathrm{CO}_{2}$ em seu interior é relacionada à manutenção da qualidade do produto. No caso dos 
acondicionamentos preservativos torna-se crítico, pois filmes plásticos podem ser de 2 a 8 vezes mais permeáveis ao $\mathrm{CO}_{2}$ do que ao $\mathrm{O}_{2}$ (Jeremiah, 2001). Some-se a isso o fato do $\mathrm{CO}_{2}$ estar presente na atmosfera da embalagem em concentrações muito mais altas que as atmosféricas $(0,03 \%)$. Assim a diferença entre a concentração de $\mathrm{CO}_{2}$ no interior e no exterior da embalagem é geralmente maior que a de $\mathrm{O}_{2}$ (Sarantopoulos et al., 1996).

A maioria dos filmes para acondicionamento preservativo de carne é combinação de materiais de estruturas multicamadas que incorporam uma variedade de resinas poliméricas; esta construção pode ser feita por laminação ou coextrusão (Sarantopoulos et al., 1996). O objetivo é obter propriedades superiores, por exemplo, uma camada central de cloretos de polivinilideno (PVDC) com alta barreira a gases, uma camada interna com superior propriedade de selagem a quente (polietileno ou ionômeros) e uma camada externa resistente a danos mecânicos, como Nylon. Os laminados também provêm encolhimento, resistência a deformação, clareza, transparência e características anti-embaçantes. Tanto o PVDC quanto o copolímero de etileno e ácool vinilico (EVOH) apresentam excelentes características de barreira ao vapor d'água e gases. A poliamida (Nylon) tem relativamente pobre propriedade de barreira a vapor d'água, mas relativamente boa propriedade de barreira a gases. Entretanto, as propriedades de barreira ao vapor d'água podem ser melhoradas com orientação das camadas de polipropileno ou polietileno (Stiles, 1991; Sarantopoulos et al., 2002).

A selagem da embalagem deve ser a quente em todo o perímetro e podem ser usados vários tipos de selantes, que usualmente representam a camada mais espessa dos laminados (Gill, 1991; Stiles, 1991; Gill, 1992).

Os filmes esticáveis são usados porque, estando completamente aderidos à superfície do produto, contribuem na manutenção de cor (Gokalp et al., 1978) evitando a formação de vacuidades onde se desenvolveria uma atmosfera contendo variadas concentrações de oxigênio (Gill, 1992), além de serem espaços para a acumulação de líquido exsudado (Stiles, 1991). O líquido exsudado que se acumula nas vacuidades, torna-se turvo na medida que pigmentos dissolvidos nele se oxidam, causando deposição de metamioglobina na superfície da carne (Gill, 1992). O filme tem que ser aplicado aderido bem justo a toda a superfície do produto ou contra a superfície do 
filme primário, assim o oxigênio ingressante será absorvido pelos componentes do produto (Gill, 1992).

Conhecer o vetor crítico de deterioração do alimento e as variáveis que o afetam é fundamental num dimensionamento criterioso de embalagem. Além disto, devem ser considerados aspectos como: compatibilidade do produto com o tipo de embalagem e sistema de fechamento (maquinabilidade), tecnologias disponíveis, ciclo de vida médio do produto, legislação, conveniência e comunicação através da embalagem, considerações toxicológicas e ambientais com respeito à fabricação, uso e descarte, e viabilidade econồmica em função do valor intrínseco do produto (Sarantopoulos \& Oliveira, 1991).

\subsubsection{Sistema e equipamento de acondicionamento eficientes}

. Estabelecer procedimentos para execução do acondicionamento em atmosfera modificada é de importância prática para o sucesso da aplicação e se refletem na vida útil de exposição e venda do produto. Atrasos e demora antes do acondicionamento permitem que se forme metamioglobina, a qual reduz a intensidade do blooming (Ernst, 1980), mas se a concentração de oxigênio na embalagem com atmosfera controlada for, como deve ser, reduzida abaixo de $10 \mathrm{~mm}$ dentro de 10 minutos a partir do fechamento da embalagem, para carne estocada a $2^{\circ} \mathrm{C}$, ou dentro de 2 horas, quando a carne for estocada a $-1,5^{\circ} \mathrm{C}$, haverá a prevenção de descoloração transiente (Gill \& McGinnis, 1995). Utilizar bom nível de vácuo, no minimo 50,8 cm, na evacuação da embalagem, acelera a redução a deoximioglobina e a oxigenação a oximioglobina (reblooming), depois da abertura da mesma (Rikert et al., 1957).

O equipamento de acondicionamento, utilizado para remoção da atmosfera original da embalagem e a introdução da nova atmosfera é também um ponto critico para o sucesso da tecnologia. Os equipamentos com 1 ciclo de evacuação e injeção, de boa eficiência podem resultar em concentração residual de oxigênio na embalagem de até $10 \%$, mas, com múltiplos ciclos de evacuação e injeção de gás, geralmente alcançam concentrações residuais de oxigênio de cerca de 1\%. Entretanto, quando a evacuação é feita através de bico de injeção tipo lança retrátil (snorkel) à pressão 
atmosférica e dentro de câmaras de evacuação, concentrações residuais de oxigênio de cerca de $0,1 \%$ são alcançadas em acondicionamento com atmosfera modificada com baixo oxigênio (Jeyamkondan et al., 2000).

Em acondicionamentos preservativos com atmosfera modificada ou a vácuo é essencial que o nível de oxigênio residual seja mínimo. Se o oxigênio lpuder ser efetivamente removido da embalagem antes da selagem ou excluído durante a estocagem, a descoloração será evitada. Idealmente, deve ser efetuada a rápida evacuação do ar do interior da embalagem, a nivel nominalmente anóxico, isto é, menos que 500 ppm, porém, pode ocorrer da concentração de oxigênio não ser reduzida a menos que $1,5 \%$, devido ao ar ocluso na embalagem (Clark \& Burki, 1972). Os niveis de oxigênio residual $>0,15 \%$ podem produzir descoloração transiente e escurecimento irreversivel, depois de prolongada estocagem (Jeremiah, 2001).

Os sistemas de embalagem de transporte com atmosfera modificada (ATM) para carnes frescas são compostos por embalagens primárias de alta permeabilidade ao $\mathrm{O}_{2}$, colocadas em embalagem secundária ou Masterpack, de baixa permeabilidade a gases. Os sistemas que utilizam $\mathrm{CO}_{2}$ puro, devem conferir um ambiente anaeróbico, somado ao efeito bacteriostático do $\mathrm{CO}_{2}$. Recomenda-se para sistemas que utilizam $\mathrm{CO}_{2}$ puro, um residual de $\mathrm{O}_{2}$ de no máximo $0,1 \%$ e, preferivelmente, não mais que $0,05 \%$ para minimizar a descoloração. Nestes sistemas, a carne fresca apresenta coloração arroxeada, devido à ausência de $\mathrm{O}_{2}$, semelhante à da embalada a vácuo. As carnes das embalagens primárias ao serem removidas do Masterpack e expostas ao ar atmosférico para venda, readquirem cor vermelho intensa, processo este denominado reblooming (Sarantopoulos et al., 2001). A possibilidade de aumento da vida útil, pela utilização do sistema Masterpack, pode permitir a centralização do processamento de cortes de carne em bifes e promover a substituição da forma tradicional de distribuição de carcaças e quartos bovinos entre abatedouros e açougues, pela comercialização de cortes de carnes, previamente preparados e embalados em plantas processadoras especialmente desenvolvidas (Hood \& Mead, 1993).

A tecnologia de embalagem em atmosfera modificada tem sido utilizada, pois permite um aumento da vida útil do produto, possibilitando maior tempo de comercialização com melhor qualidade. A resposta das indústrias de alimentos tem sido investir em novas tecnologias confiáveis que satisfaçam esta demanda. Entretanto, apesar de todos os beneficios obtidos do uso do sistema de atmosfera 
modificada, a realidade brasileira para carnes frescas, no momento, mostra uma retração deste mercado. Muito foi investido nesta tecnologia por parte dos frigoríficos e, atualmente, a linha varejo de carne fresca em atmosfera modificada encontra-se, em muitos locais, desativada. O que acontece é que a carne embalada em atmosfera modificada deixa os frigoríficos em boas condições de qualidade e no mercado varejista surge uma série de problemas, principalmente de ordem microbiológica, e o produto, conseqüentemente, não é aceito e é retornado aos frigoríficos. $O$ que os frigorificos mais têm contestado são as condições de manuseio e estocagem destes produtos no mercado varejista, principalmente a cadeia do frio, condição fundamental para eficiência do sistema com atmosfera modificada. Assim, o que se observa no mercado brasileiro é que uma tecnologia de conservação de alimentos extremamente eficiente e viável comercialmente tem sido impossibilitada de ser aplicada para carne fresca devido às condições de comercialização do mercado varejista. Durante o transporte e distribuição, os produtos estão sujeitos a esforços mecânicos, que se não forem devidamente considerados, poderão produzir efeitos danosos bastante severos e onerosos. Um dos principais esforços sofridos pelos produtos durante o transporte são os movimentos vibratórios. A sua análise é fundamental no perfeito desenvolvimento e especificação do sistema de embalagem. No caso das embalagens em atmosfera modificada, o efeito das vibrações e choques de transporte e manuseio pode acarretar perdas na integridade do fechamento da embalagem e conseqüente alteração da composição gasosa. A influência do transporte consiste de uma etapa de análise de falhas no sistema (Conceição et al., 2001). 


\section{MATERIAL E MÉTODOS}

\subsection{Acondicionamento do produto}

Foram comprados $150 \mathrm{~kg}$ de carré suíno de um frigorífico comercial, 24 horas após o abate, para a utilização no estudo. Foram acondicionados no mesmo dia da desossa, de forma asséptica em caixas de isopor com gelo e transportados em 40 minutos para o Centro de Tecnologia de Carnes (CTC) no Instituto de Tecnologia de Alimentos (ITAL) em Campinas, SP, onde foi feito o estudo da vida útil. Ao chegarem ao CTC, os carrés foram armazenados em câmara frigorífica com temperatura de $0^{\circ} \mathrm{C}$ a $-3^{\circ} \mathrm{C}$ na ausência de luz, durante 24 horas antes de começar o processamento, com o fatiamento do carré em bistecas e posterior estudo da vida útil.

Foram distribuídas 4 bistecas em bandeja de poliestireno não expandido (aproximadamente $0,550 \mathrm{~kg}$ ) sobre película absorvedora de líquido e envolvida pelo filme termoencolhivel de PVC (policloreto de vinila), o qual foi esticado automaticamente em um equipamento da marca Pulit modelo semi-automático para dar um fechamento na embalagem, que foi denominada de Embalagem Primária. Em seguida, seis embalagens primárias foram colocadas dentro de um Masterpack (Embalagem Secundária). Os Masterpacks foram evacuados, injetados com misturas gasosas de ATM e selados.

A modificação da atmosfera nas embalagens Masterpack foi feita no interior de uma máquina Securefresh, modelo SP 10, produzido por Securefresh Pacific Limited (Auckland, Nova Zelândia). Este equipamento possui câmara de evacuação que extrai todo o ar da embalagem, inclusive do interior da bandeja e realiza a injeção da nova mistura gasosa através de bicos injetores de gás tipo lança (snorkel), em uma razão aproximada de 1,0 litro de gás $/ \mathrm{kg}$ de carne. No acondicionamento a vácuo as 
bistecas foram acondicionadas nas bandejas, da mesma forma que nos tratamentos com gases, no entanto as embalagens secundárias eram filmes termoencolhiveis $\left(\right.$ Cryovac $^{R}$ ), de material laminado composto por polietileno de baixa densidade (EVA/PVDC/EVA), espessura $100 \mu \mathrm{m}$, de alta barreira ao oxigênio, apresentando taxa de permeabilidade a este gás de $1,87 \mathrm{~cm} 3$ (CNTP)/m2/dia, $1 \mathrm{~atm}, 23^{\circ} \mathrm{C}, 0 \%$ UR. Essas embalagens foram embaladas a vácuo, individualmente, em seladora marca Digimat, modelo Supervac GK 185, de fabricação austríaca.

Os gases utilizados no estudo, $100 \%$ gás carbônico $\left(\mathrm{CO}_{2}\right)$ e a mistura $50 \%$ $\mathrm{CO}_{2} / 50 \% \mathrm{~N}_{2}$ foram fornecidos em cilindros da empresa White Martins Gases Industriais S.A., linha alimentícia.

A empresa UNIPAC Embalagens Ltda. forneceu as embalagens Masterpacks com estruturas comerciais denominadas Univac HQ $100 \mu \mathrm{m}$ que eram constituídas de filmes co-extrusados de PA/EVOH/PEBD de filmes de baixa densidade com dimensões de $600 \times 800 \mathrm{~mm}$ (largura $\times$ comprimento), sendo a camada de PA a mais externa, a camada de EVOH a intermediária e a camada de PEBD a mais interna; a empresa Emplal Embalagens Ltda. forneceu as bandejas de poliestireno não expandido de dimensões de $12 \times 238 \times 182 \mathrm{~mm}$ (altura $\times$ comprimento $\times$ largura), a empresa Cryovac Brasil Ltda. forneceu os absorvedores de líquido Dry Loc e a empresa Pulit Embalagens forneceu as embalagens poliolefínicas que eram filmes constituídos de PVC formatados em sacos de dimensões $370 \times 220 \mathrm{~mm}$ (comprimento $x$ largura).

\subsection{Delineamento do experimento}

A pesquisa envolveu 3 tratamentos: Tratamento $1\left(100 \% \mathrm{CO}_{2}\right)$, Tratamento 2 $\left(50 \% \mathrm{CO}_{2} / 50 \% \mathrm{~N}_{2}=\right.$ mistura) e Tratamento 3 (vácuo = controle), sendo que a unidade experimental era $\circ$ Masterpack contendo 6 embalagens primárias, para os tratamentos com atmósfera gasosa e, para o tratamento vácuo; a unidade experimental era representada por um conjunto de 6 bandejas individuais embaladas a vácuo.

Para cada tratamento com atmosfera gasosa $\left(100 \% \mathrm{CO}_{2}\right.$ e mistura) foram preparadas 8 embalagens Masterpack (embalagem secundária) e cada embalagem era composta de 6 bandejas com aproximadamente $0,550 \mathrm{~kg}$ de bisteca suina cada 
(com 4 bistecas por bandeja) embaladas em filme de PVC (embalagem primária). Os tratamentos foram replicados, portanto cada tratamento tinha 16 Masterpacks, totalizando 96 bandejas estudadas. Com relação ao tratamento vácuo, foram preparadas 54 embalagens individuais, nas mesmas condições dos tratamentos com atmosfera gasosa, exceto que o processo de evacuação e selagem das embalagens secundárias foi feito individualmente.

Após o preparo, todos os Masterpacks e embalagens a vácuo foram armazenados a temperaturas variando de $0^{\circ} \mathrm{C}$ a $+3^{\circ} \mathrm{C}$, na ausência de luz, para o estudo da vida útil.

As amostras foram removidas após período de estocagem correspondente a $5,11,18,25$ e 32 dias, selecionadas aleatoriamente dentro das unidades experimentais e foram avaliadas quanto à composição gasosa do espaço-livre (exceto o tratamento à vácuo), caracteristicas físicas e químicas, qualidade microbiológica e sensorial.

\subsection{Determinação microbiológica}

A bisteca suína destinada ao estudo de vida útil foi submetida a análises microbiológicas de caracterização, consistindo dos seguintes testes: Salmonella, coliformes fecais, Staphylococcus aureus, Listeria monocytogenes, contagem padrão de microrganismos mesófilos aeróbios, bactérias lácticas, Pseudomonas $s p$, microrganismos psicrotróficos e Enterobactérias, de acordo com as metodologias descritas por Mead \& Adams (1977), ICMSF (1978) e Vanderzant \& Splittstoesser (1992). A unidade analítica para a análise das bistecas suinas foi de $25 \mathrm{~g}$, retirada assepticamente da amostra e transferida para um agitador estéril com $225 \mathrm{~mL}$ de água peptonada $0,1 \%$, utilizada para fazer as diluições decimais seriadas subseqüentes tantas quantas necessárias para a obtenção das contagens bacterianas desejadas.

\subsubsection{Salmonella sp}

Para a pesquisa de Salmonella $s p$, foram coletadas porções superficiais das 
bistecas, seguindo de pesagem asséptica de $25 \mathrm{~g}$ de amostra em balança semianalítica, realizada no laboratório. O pré-enriquecimento foi realizado diluindo-se as $25 \mathrm{~g}$ de amostra em $225 \mathrm{~mL}$ de solução salina peptonada tamponada (BPW, OXOID, CM509) com posterior incubação em estufa BOD a $35^{\circ} \mathrm{C}$ por $24 \mathrm{~h}$, objetivando-se a recuperação das células injuriadas. A seguir, alíquotas do meio de pré-enriquecimento foram transferidas para tubos contendo caldos de enriquecimento seletivo. Para tanto, foram utilizados tubos contendo $10 \mathrm{ml}$ do Caldo Tetrationato (TT, OXOID, CM343) e do Caldo Rappaport Vassiliadis (RV, OXOID, CM866), transferindo-se $1,0 \mathrm{ml}$ e $0,1 \mathrm{ml}$ do inoculo, respectivamente. $O$ Caldo TT foi incubado em estufa BOD a $35^{\circ} \mathrm{C}$ por $24 \mathrm{~h}$ e o Caldo RV em banho-maria a $42^{\circ} \mathrm{C}$ por $24 \mathrm{~h}$. Realizou-se o plaqueamento seletivo diferencial em Agar Entérico de Hectoen (HE, OXOID, CM419) e Agar Xilose Lisina Desoxicolato (XLD, OXOID, CM469), com incubação a $35^{\circ} \mathrm{C}$ por $24 \mathrm{~h}$. A confirmação das colônias típicas de Salmonella sp.foi realizada por meio de testes bioquímicos e sorológicos, que constavam de teste sorológico somático polivalente; teste de urease; teste de indol; teste de malonato; teste da fermentação da lactose e sacarose; teste de vermelho de metila e VogesProskauer; teste de citrato; teste de descarboxilação da lisina em caldo e teste sorológico flagelar polivalente. O resultado foi expresso em presença ou ausência em $25 \mathrm{~g}$, conforme Vanderzant \& Splittstoesser (1992).

\subsubsection{Coliformes fecais}

Para a realização da enumeração de coliformes fecais, primeiro realizou-se a enumeração de coliformes totais, onde selecionou-se três duluições decimais adequadas da amostra $(1: 10,1: 100,1: 1000)$ adicionando-se $1 \mathrm{ml}$ em tubos de ensaio contendo $5 \mathrm{ml}$ de Caldo Lauril Sulfato Triptose suplementado com 4-metilumbeliferil- $\beta$ D-glicuronídeo (LST-MUG, Merck, 12588). A incubação foi realizada em estufa incubadora BOD a $35^{\circ} \mathrm{C}$ por $48 \mathrm{~h}$, seguida de leitura sob luz UV ( 3 a $6 \mathrm{~W}$ ), ondas longas $(365 \mathrm{~nm})$ em cabine escura. Os tubos de LST-MUG com produção de gás foram submetidos a testes de confirmação de coliformes fecais em Caldo E. coli (EC, Merck, 105454), incubados em estufa BOD a $45,5^{\circ} \mathrm{C}$ por $24 \mathrm{~h}$. A confirmação de coliformes fecais foi positiva para os tubos de Caldo EC que apresentaram produção de gás. A partir dos tubos positivos para coliformes fecais determinou-se o NMP em tabela 
adequada às diluições utilizadas. Os resultados foram expressos em NMP/g (Vanderzant \& Splittstoesser, 1992).

\subsubsection{Staphylococcus aureus}

A contagem de $S$. aureus foi realizada pelo método de plaqueamento em superficie, de acordo com Vanderzant \& Splittstoesser (1992). Para tanto, selecionouse duas diluições adequadas da amostra e estas foram inoculadas em placas de Petri estéreis contendo o meio de cultura Agar Baird-Parker (BP, OXOID, CM365) suplementado a $1 \%$ com solução de telurito de potássio a $10 \%$. A inoculação foi realizada em 4 placas distintas, distribuindo-se o volume de $1 \mathrm{ml}$ da primeira diluição em alíquotas de 0,$3 ; 0,3 ; 0,3 ; 0,1 \mathrm{ml}$. Após o espalhamento do inoculo nas placas com o auxilio de alça de Drigalski, as mesmas foram incubadas invertidas em estufa incubadora BOD a $35^{\circ} \mathrm{C}$ por $48 \mathrm{~h}$. Realizou-se a confirmação de colônias típicas de $S$. aureus (circulares, pretas, pequenas, rodeadas por uma zona opaca e um halo transparente) por meio dos testes de catalase, coagulase e coloração de Gram. Os resultados foram expressos em UFC/g.

\subsubsection{Listeria monocytogenes}

Para a análise de Listeria monocytogenes foi feito um enriquecimento seletivo primário da amostra em caldo Universidade de Vermont (UVM), incubando-se a $30^{\circ} \mathrm{C}$ por 24 horas. Em seguida transferiu-se $0,1 \mathrm{ml}$ do Caldo UVM para um tubo com $10,0 \mathrm{ml}$ de Caldo Fraser, o qual foi incubado a $30^{\circ} \mathrm{C}$ por 24 horas. Em caso positivo de reação no Caldo Fraser (ocorrência de escurecimento do caldo) procedeuse ao plaqueamento seletivo diferencial, onde passou-se para uma placa de Petri estéril contendo Agar Oxford Modificado (MOX), incubando-se a $35^{\circ} \mathrm{C}$ e observou-se a presença de colônias típicas com 24 e 48 horas de incubação (colônias esféricas, pretas, rodeadas por um halo preto de hidrólise da esculina). Selecionou-se colônias típicas de cada placa para confirmação em placas com Agar Tripticase de Soja, suplementado com $0,6 \%$ de extrato de levedura (TSA-YE), para purificação e incubou- 
se a $30^{\circ} \mathrm{C}$ durante 24 horas. Em seguida, procedeu-se aos testes bioquímicos: Teste de Catalase ( $L$. monocytogenes é catalase positiva), Teste de Motilidade ( $L$. monocytogenes são móveis, com migração característica, lembrando um guardachuva), Teste de Nitrato (apresenta reação resultando em coloração rósea), Reação em Agar Tríplice Açúcar Ferro (TSI) (observar a reação típica: uma rampa e fundos amarelos (ácidos) sem produção de $\mathrm{H}_{2} \mathrm{~S}$ (não escurecimento do agar)), Teste de verificação de hemólise (observar a formação de halos discretos que não se estendem muito para fora da região da colônia), Teste de fermentação da dextrose, xilose, rhamnose, manitol, maltose e esculina (observar a fermentação da rhamnose e não da xilose e do manitol), CAMP-teste (com reação de hemólise discreta ao redor do halo), visto que todas as outras etapas estavam tendo confirmação para Listeria e os testes bioquímicos determinaram a espécie $L$. monocytogenes. $O$ resultado foi expresso em presença ou ausência em $25 \mathrm{~g}$ (Vanderzant \& Splittoesser, 1992).

\subsubsection{Contagem padrão de microrganismos mesófilos aeróbios totais}

As contagens totais de bactérias mesófilas aeróbias foram realizadas pelo método de plaqueamento em profundidade, segundo Vanderzant \& Splittstoesser (1992). Para tanto, aliquotas de $1 \mathrm{ml}$ da amostra diluída foram inoculadas em placas de Petri estéreis. O meio de cultura Agar Padrão para Contagem (PCA, OXOID, CM235) foi vertido sobre as mesmas, seguindo-se de incubação em estufa $\mathrm{BOD}$ a $35^{\circ} \mathrm{C}$ por 48 horas. Para a contagem foram selecionadas as placas com 25-250 colônias e os resultados foram expressos em UFC/g (Vanderzant \& Splittoesser, 1992).

\subsubsection{Bactérias lácticas}

Para a contagem de bactérias lácticas foi utilizado o método de plaqueamento em profundidade, segundo Vanderzant \& Splittstoesser (1992). Para tanto, alíquotas de $1 \mathrm{ml}$ da amostra diluída foram inoculadas em placas de Petri estéreis e, em seguida, o meio de cultura Agar de Man, Rogosa \& Sharpe (MRS, OXOID, CM361) foi vertido sobre as mesmas. Após a solidificação do agar, a superfície das 
placas foi recoberta por uma sobrecamada do mesmo meio, a fim de promover uma atmosfera microaerófila. As placas foram incubadas em estufa BOD a $30^{\circ} \mathrm{C}$ por $72 \mathrm{~h}$. Para a contagem foram selecionadas as placas com 25-250 colônias e os resultados foram expressos em UFC/g (Vanderzant \& Splittoesser, 1992).

\subsubsection{Enterobactérias}

A contagem de enterobactérias foi realizada pelo método de plaqueamento em profundidade conforme descrito pela International Comission on Microbiological Specifications for Foods - ICMSF (1978). Aliquotas de $1 \mathrm{ml}$ da amostra diluída foram inoculadas em placas de Petri estéreis e, em seguida, o Ágar Violet Red Bile Glucose (VRBGA, OXOID, CM485) foi vertido sobre as mesmas. Após a solidificação do agar, a superfície das placas foi recoberta por uma sobrecamada do mesmo meio de cultura, a fim de promover uma atmosfera de microaerofilia. As placas foram incubadas em estufa BOD a $35^{\circ} \mathrm{C}$ por $48 \mathrm{~h}$. Para a contagem foram selecionadas as placas com 25250 colônias e os resultados foram expressos em UFC/g (Vanderzant \& Splittoesser, 1992).

\subsubsection{Microrganismos psicrotróficos aeróbios}

As contagens totais de bactérias psicrotróficas aeróbias foram realizadas pelo método de plaqueamento em profundidade, segundo Vanderzant \& Splittstoesser (1992). Para tanto, alíquotas de $1 \mathrm{ml}$ da amostra diluída foram inoculadas em placas de Petri estéreis. O meio de cultura Agar Padrão para Contagem (PCA, OXOID, CM235) foi vertido sobre as mesmas, seguindo-se de incubação em estufa BOD a $20^{\circ} \mathrm{C}$ por $72 \mathrm{~h}$. Para a contagem foram selecionadas as placas com $25-250$ colônias e os resultados foram expressos em UFC/g (Vanderzant \& Splittoesser, 1992). 


\subsubsection{Pseudomonas sp.}

A contagem de Pseudomonas sp. foi realizada pelo método de plaqueamento em superfície segundo Mead \& Adams (1977). As amostras foram inoculadas em placas de Petri estéreis contendo o meio de cultura Agar Pseudomonas (AP, OXOID, CM559) adicionado do suplemento Cetrimida, Fucidina, Cefaloridina (CFC, OXOID, SR103) e glicerina a 1\%. A inoculação foi realizada em 4 placas distintas, distribuindo-se o volume de $1 \mathrm{ml}$ da primeira diluição em alíquotas de 0,$3 ; 0,3$; 0,3 e $0,1 \mathrm{ml}$. O espalhamento do inóculo nas placas foi realizado com o auxílio de alça de Drigalski e, em seguida, as placas foram incubadas em estufa incubadora BOD a $20^{\circ} \mathrm{C}$ por $72 \mathrm{~h}$. Para a contagem foram selecionadas as placas com 25-250 colônias e os resultados foram expressos em UFC/g (Vanderzant \& Splittoesser, 1992).

A Tabela 1 apresenta o sumário das metodologias empregadas nas análises microbiológicas: 
Tabela 1. Metodologias analíticas empregadas nas análises microbiológicas

\begin{tabular}{|c|c|c|c|}
\hline Bactéria & $\begin{array}{l}\text { Referência do } \\
\text { Procedimento }\end{array}$ & $\begin{array}{l}\text { Procedimento de } \\
\text { enumeração }\end{array}$ & Incubação \\
\hline Salmonella sp. & $\begin{array}{c}\text { Vanderzant \& } \\
\text { Splittstoesser (1992) }\end{array}$ & $\begin{array}{c}\text { Determinação } \\
\text { qualitativa }\end{array}$ & $35^{\circ} \mathrm{C} / 24 \mathrm{~h}$ \\
\hline Coliformes fecais & $\begin{array}{c}\text { Vanderzant \& } \\
\text { Splittstoesser (1992) }\end{array}$ & Tubos múltiplos & $35^{\circ} \mathrm{C} / 48 \mathrm{~h}$ \\
\hline S. aureus & $\begin{array}{c}\text { Vanderzant \& } \\
\text { Splittstoesser (1992) }\end{array}$ & $\begin{array}{l}\text { Plaqueamento por } \\
\text { superfície }\end{array}$ & $35^{\circ} \mathrm{C} / 48 \mathrm{~h}$ \\
\hline L. monocytogenes & $\begin{array}{c}\text { Vanderzant \& } \\
\text { Splittstoesser (1992) }\end{array}$ & $\begin{array}{l}\text { Plaqueamento por } \\
\text { superfície }\end{array}$ & $30^{\circ} \mathrm{C} / 24 \mathrm{~h}$ \\
\hline $\begin{array}{l}\text { Contagem total de } \\
\text { mesófilos aeróbios }\end{array}$ & $\begin{array}{c}\text { Vanderzant \& } \\
\text { Splittstoesser (1992) }\end{array}$ & $\begin{array}{l}\text { Plaqueamento por } \\
\text { profundidade }\end{array}$ & $35^{\circ} \mathrm{C} / 48 \mathrm{~h}$ \\
\hline Bactérias lácticas & $\begin{array}{c}\text { Vanderzant \& } \\
\text { Splittstoesser (1992) }\end{array}$ & $\begin{array}{l}\text { Plaqueamento por } \\
\text { profundidade }\end{array}$ & $30^{\circ} \mathrm{C} / 72 \mathrm{~h}$ \\
\hline Enterobactérias & ICMSF (1978) & $\begin{array}{l}\text { Plaqueamento por } \\
\text { profundidade }\end{array}$ & $35^{\circ} \mathrm{C} / 24 \mathrm{~h}$ \\
\hline $\begin{array}{c}\text { Bactérias psicrotróficas } \\
\text { aeróbicas }\end{array}$ & $\begin{array}{c}\text { Vanderzant \& } \\
\text { Splittstoesser (1992) }\end{array}$ & $\begin{array}{c}\text { Plaqueamento por } \\
\text { profundidade }\end{array}$ & $20^{\circ} \mathrm{C} / 72 \mathrm{~h}$ \\
\hline Pseudomonas sp. & Mead \& Adams (1977) & $\begin{array}{c}\text { Plaqueamento por } \\
\text { superfície }\end{array}$ & $20^{\circ} \mathrm{C} / 72 \mathrm{~h}$ \\
\hline
\end{tabular}

A qualidade microbiológica da bisteca suína foi monitorada durante o estudo da vida útil através das contagens de bactérias lácticas, enterobactérias, bactérias psicrotróficas aeróbias e Pseudomonas $s p$. Os métodos empregados para avaliações microbiológicas foram realizados segundo metodologias descritas por Mead \& Adams (1977), ICMSF (1978), Vanderzant \& Splittoesser (1992), como descritos nos itens 3.3.6, 3.3.7, 3.38 e 3.3.9, respectivamente, com os resultados expressos em unidades formadoras de colônias (UFC/g). 


\subsection{Caracterização das embalagens}

As embalagens primárias (filme PVC) foram caracterizadas quanto à taxa de permeabilidade ao $\mathrm{CO}_{2}$ e ao $\mathrm{O}_{2}$.

As embalagens secundárias (Masterpacks) para acondicionamento em atmosfera modificada foram caracterizadas quanto à taxa de permeabilidade ao $\mathrm{O}_{2}$.

\subsubsection{Taxas de permeabilidade ao $\mathrm{O}_{2}$}

A taxa de permeabilidade ao oxigênio das embalagens primária e secundária foi determinada por métodos coulométricos, segundo norma ASTM D 3985-81 ("Standard test method for oxygen gas transmission rate through plastic film and sheeting using a coulometric sensor") citado em Padula et al. (1989). Neste ensaio utilizou-se equipamento OXTRAN, modelo 100 TWIN, da MOCON, operando com oxigênio puro com gás permeante à temperatura de $24^{\circ} \mathrm{C}$ e a seco. Durante o teste o fluxo do gás de arraste foi mantido a $10 \mathrm{~mL} / \mathrm{min}$ e do oxigênio a $20 \mathrm{~mL} / \mathrm{min}$. A área efetiva de permeação foi de $100 \mathrm{~cm}^{2}$. O condicionamento dos corpos-de-prova foi feito durante dois dias a $24^{\circ} \mathrm{C}$ e a seco. Os resultados obtidos foram corrigidos para $1 \mathrm{~atm}$ de gradiente de pressão parcial de oxigênio.

\subsubsection{Taxas de permeabilidade ao $\mathrm{CO}_{2}$}

As taxas de permeabilidade ao gás carbônico foram determinadas por método de aumento da concentração, segundo procedimento descrito em detalhes na publicação "Embalagens Plásticas Flexíveis - principais polímeros e avaliação de propriedades; Campinas: ITAL/CETEA, 2002, 267p". Neste ensaio foram utilizadas células de difusão, nas quais um corpo-de-prova foi fixado, formando duas câmaras: superior e inferior. $\mathrm{Na}$ câmara superior foi mantido um fluxo de gás permeante, que ao permear o corpo-de-prova acumulou-se na câmara inferior, fechada para a atmosfera. A intervalos pré-determinados, foram retiradas alíquotas de gás da câmara onde foi acumulado o gás permeante, com seringa hermética, através de um septo, para a 
quantificação do gás permeante em cromatógrafo a gás CG Instrumentos Científicos, modelo 2527 , operando com detetor de condutividade térmica a $141^{\circ} \mathrm{C}$, coluna Porak (Q) a $82^{\circ} \mathrm{C}$ e injetor a $84^{\circ} \mathrm{C}$. Os resultados de cromatografia foram analisados por um integrador Shimadzu, modelo CR4A, com base em curvas padrões feitas com gases de calibração. A área efetiva de permeação foi de $47 \mathrm{~cm}^{2}$. Os ensaios foram conduzidos a $23^{\circ} \mathrm{C}$ e a seco. Os resultados obtidos foram corrigidos para $1 \mathrm{~atm}$ de gradiente de pressão parcial de gás permeante.

\subsection{Análise da composição gasosa do espaço livre}

Os teores de $\mathrm{O}_{2}$ e $\mathrm{CO}_{2}$ no espaço-livre do Masterpack foram determinados em um Analisador de Gás ILLINOIS (onde a agulha do aparelho era inserida na embalagem através de um septo, para evitar perfuração), no dia do processamento (embalagem) e no período de estocagem correspondente a 5, 11, 18, 25 e 32 dias, sendo que amostras foram selecionadas aleatoriamente dentro das unidades experimentais. Os valores de $\mathrm{N}_{2}$ foram determinados por diferença de porcentagem dos outros gases. Os resultados finais foram expressos como porcentagens de volume de $\mathrm{O}_{2}, \mathrm{CO}_{2}$ e $\mathrm{N}_{2}$ (McMullen \& Stilles, 1991). Essa análise foi realizada em 2 embalagens Masterpack do tratamento 1 e em 2 embalagens Masterpack do tratamento 2 .

\subsection{Coloração instrumental}

A cor da superficie das bistecas suinas foi avaliada na matéria-prima e durante a vida útil $\left(5^{\circ}, 11^{\circ}, 18^{\circ}, 25^{\circ}\right.$ e $32^{\circ}$ dias de armazenamento) 30 minutos após a abertura das embalagens secundárias (para a re-oxigenação da mioglobina, com exposição aeróbia em temperaturas de $4 \pm 1^{\circ} \mathrm{C}$ ), através do filme primário. A determinação da coloração foi feita com o auxílio de um espectrofotômetro portátil MINOLTA modelo CM508d, utilizando iluminante D65 com ângulo de abertura de $10^{\circ}$, no sistema CIE Lab (Macdougall, 1999). Foram tomadas 12 medidas de cada bandeja por tratamento, sendo 3 bandejas por tratamento. A média das 12 medidas de leitura 
realizadas nas bistecas suinas foram gravadas em um "software" (Spectra Magic, Minolta, Japão) acoplado ao espectrofotômetro (Minolta, 1998).

\subsection{Determinação do pH}

Os valores de $\mathrm{pH}$ foram medidos na matéria-prima e, durante o estudo da vida útil $\left(5^{\circ}, 11^{\circ}, 18^{\circ}, 25^{\circ}\right.$ e $32^{\circ}$ dias de armazenamento), imediatamente após a leitura da coloração instrumental, utilizando pHmetro DIGIMED DM-21 com eletrodo de punção diretamente no produto conforme metodologia descrita por Velazco (1991). Foram tiradas medidas de 3 pontos em cada uma das 4 bistecas de cada bandeja, sendo utilizadas 3 bandejas por tratamento.

\section{8 Índice de TBA}

Um dos métodos mais utilizados em produtos cárneos para se avaliar a extensão da estabilidade lipídica é o teste de TBA (ácido 2-tiobarbitúrico) ou TBARS (substâncias reativas ao ácido 2-tiobarbitúrico). Nesse método, o malonaldeído, um produto de oxidação lipídica, após ser obtido por destilação, reage sob aquecimento com o ácido tiobarbitúrico, produzindo coloração rósea que pode ser medida espectrofotometricamente e comparada com a absorção da curva padrão. Assim, as amostras (controle e com gases) de bisteca suína foram avaliadas segundo metodologia descrita por Tarladgis et al. (1960).

\subsection{Análise sensorial}

Utilizou-se a Análise Descritiva Quantitativa desenvolvida por Stone et al. (1974), modificada para descrever as principais características que compõem o sabor, aroma e aparência de um alimento, além de medir a intensidade das sensações percebidas.

Os julgadores faziam parte da equipe de análise sensorial do CTC/ITAL e já 
haviam participado em outros estudos de avaliação de carne suína in natura. Em uma mesa redonda foram realizadas as discussões abertas para obtenção da lista de atributos, referências, fichas de avaliação e treinamento dos julgadores.

Os termos descritivos dos atributos sensoriais foram baseados na literatura, com trabalhos utilizando atmosferas gasosas para estender a vida útil da bisteca suína (Sorheim et al., 1996).

Após treinamento, os julgadores avaliaram três amostras, com três repetições, utilizando os termos sugeridos no parágrafo anterior e foram selecionados de acordo com a habilidade de discriminar as amostras, com repetibilidade e através da coerência com a equipe sensorial. Para obter informações sobre a repetibilidade $e$ sobre o poder de discriminação destes julgadores foram realizadas análises de variância (ANOVA) de dois fatores (repetições e amostras) para cada um deles, com os resultados de cada um dos atributos em separado, como recomendam Damásio \& Costell (1991).

Essa equipe treinada com sete julgadores foi utilizada para avaliar as propriedades sensoriais da bisteca suína in natura (no tempo zero, sem tratamento) e na embalada em atmosfera modificada, no $5^{\circ}, 11^{\circ}, 18^{\circ}, 25^{\circ}$ e $32^{\circ}$ dias de armazenamento.

As análises sensoriais de odor e aparência foram realizadas no tempo zero, $5^{\circ}, 11^{\circ}, 18^{\circ}, 25^{\circ}$ e $32^{\circ}$ dias, sendo retiradas três bandejas de dois pacotes Masterpack por tratamento. As amostras foram avaliadas na embalagem primária após 60 minutos da abertura dos Masterpacks. A avaliação da aparência foi realizada com a embalagem primária fechada, sob luz fluorescente do tipo luz do dia. Já a avaliação do odor foi realizada com a embalagem primária aberta, sob luz vermelha.

As análises de aparência e odor foram realizadas em cabines individuais, onde as amostras ficaram acondicionadas em um refrigerador a temperatura de $4 \pm 2^{\circ}$ $C$, na ausência de luz.

A avaliação da aparência constou de avaliações da intensidade da cor do músculo e foram realizadas utilizando escalas não estruturadas de $10 \mathrm{~cm}$, onde os extremos variavam de pouco $(0 \mathrm{~cm})$ a intenso $(10 \mathrm{~cm})$ e escala de categoria mista e vertical para cor nominal do músculo, sendo $1=$ rosa brilhante, $2=$ rosa amarronzado, $3=$ levemente marrom, 4= moderadamente marrom e 5= extremamente marrom. 
As escalas para avaliação de cor do músculo e cor da gordura foram desenvolvidas com auxílio de paletas removíveis de cor do Livro de Cor Munsell, que foram adotadas em alguns pontos âncoras das escalas lineares não estruturadas de 10 pontos:

Cor vermelha do músculo: valor $1=10 \mathrm{R} 8 / 4$; valor $5=10 \mathrm{R} 6 / 4$ e valor $10=10 \mathrm{R} 4 / 4$.

Cor marrom do músculo: valor $1=7.5 \mathrm{YR} 8 / 4$; valor $5=7.5 \mathrm{YR} 6 / 4$ e valor $10=7.5 \mathrm{YR}$ $5 / 4$.

Cor amarela da gordura: valor $1=5 \mathrm{Y} 9 / 1$; valor $5=2.5 \mathrm{Y} 9 / 2$ e valor $10=2.5 \mathrm{Y} 8.5 / 4$.

Para a determinação da "cor vermelha" e "cor marrom" do músculo foi utilizada escala não estruturada de $10 \mathrm{~cm}$, onde $0 \mathrm{~cm}$ correspondia a pouca cor e $10 \mathrm{~cm}$ a cor intensa.

A cor amarela da gordura foi determinada utilizando uma escala não estruturada de $10 \mathrm{~cm}$, onde $0 \mathrm{~cm}$ correspondia a pouca cor e $10 \mathrm{~cm}$ correspondia a cor intensa.

A cor do osso foi determinada utilizando uma escala não estruturada de $10 \mathrm{~cm}$, onde $0 \mathrm{~cm}$ correspondia a pouca cor e $10 \mathrm{~cm}$ correspondia a cor intensa.

O odor estranho ao de carne fresca foi determinado através de escala não estruturada de $10 \mathrm{~cm}$, em que: $0 \mathrm{~cm}$ correspondia a ausência de odor estranho e $10 \mathrm{~cm}$ correspondia a intenso odor estranho. Para algum odor percebido, o julgador deveria classificar qual tipo de odor sendo: 1= carne fresca, 2= guardada/geladeira, 3= fruta/doce, $4=$ fermentado, $5=$ azedo, $6=$ ranço, $7=$ deteriorada, $8=$ outros. Foi oferecido ao julgador um copinho plástico com pó de café para neutralizar o odor e evitar a fadiga entre as amostras.

A qualidade geral das amostras foi avaliada em uma escala não estruturada de $10 \mathrm{~cm}$, onde $0 \mathrm{~cm}$ correspondia a muito ruim e $10 \mathrm{~cm}$ correspondia a excelente.

Os testes foram conduzidos no Laboratório de Análise Sensorial do CTC/ITAL em cabines individuais utilizando um sistema informatizado de avaliação sensorial da COMPUSENSE® Five versão 4.2.

Bandejas com bistecas suinas embaladas em filme primário, codificadas com algarismos de três dígitos foram apresentadas aleatoriamente de forma monádica a cada julgador, com 3 repetições para cada tratamento.

$O$ delineamento experimental para a análise sensorial utilizado foi $O$ de blocos completos casualizados, considerando-se cada julgador como um bloco. A 
avaliação sensorial foi feita em três sessões onde cada julgador recebeu 3 amostras em ordem aleatória, realizando intervalo de 2 minutos entre as sessões, totalizando 9 amostras avaliadas por dia. $\mathrm{O}$ experimento durou 32 dias até que a última amostra fosse rejeitada.

\subsection{Análise dos resultados}

Os resultados provenientes das análises físico-químicas, microbiológicas e sensoriais foram submetidos a ANOVA e testes de Tukey, para comparação das médias dos tratamentos. O nivel de significância utilizado para todos os testes foi de $5 \%$. 


\section{RESULTADOS E DISCUSSÃO}

\subsection{Análise microbiológica}

As análises microbiológicas iniciais da bisteca suína, expressas em unidade formadora de colônia (UFC) e número mais provável (NMP), estão contidas na Tabela 2.

As análises demonstraram resultados satisfatórios, dentro dos padrões exigidos pela Legislação vigente (Brasil, 2001), com exceção da presença de Listeria monocytogenes, o que demonstra a provável existência de falhas nas condições higiênico-sanitárias no frigorífico fornecedor ou no processamento da matéria-prima em questão.

Embora a comparação dos valores obtidos no presente estudo seja mais adequada com a Resolução RDC n.12 (Brasil, 2001), podemos ter um referencial da grandeza dos valores apresentados em relação aos exigidos para carne fresca pelo Decreto n.12.342 (São Paulo, 1978).

Comparando os resultados do presente estudo com os encontrados na literatura, Borch et al. (1996) mostraram que a população microbiana inicial na carne e produtos cárneos pode variar de $10^{2}$ a $10^{4} \mathrm{UFC} / \mathrm{cm}^{2}$ ou $\mathrm{g}$, diferente dos resultados desse estudo, onde algumas contagens ultrapassaram esse valor (Contagem de bactérias psicrotróficas aeróbias e de Pseudomonas $s p$., ambas ao redor de $10^{5}$ UFC/g), o que pode ser devido às condições diferentes da matéria-prima utilizada nos dois estudos. 
Tabela 2. Caracterização microbiológica da bisteca suína

\begin{tabular}{lcc}
\hline \multicolumn{1}{c}{ Microrganismo } & $\begin{array}{c}\text { Valores em log } \\
\text { UFC/g }\end{array}$ & $\begin{array}{c}\text { Padrões da Legislação log } \\
\text { UFC/g }\end{array}$ \\
\hline Salmonella em 25g & Ausência & Ausência \\
Coliformes fecais (NMP) & 1,1 & $2,5^{\mathrm{b}}$ \\
Staphylococcus aureus & 2,1 & $\mathrm{nc}$ \\
Listeria monocytogenes & Presença & Ausência \\
Contagem total de & 4,6 & $6,5^{\mathrm{b}}$ \\
aeróbios mesófilos & 5,1 & $\mathrm{nc}$ \\
Psicrotróficos & 3,6 & $\mathrm{nc}$ \\
Enterobactérias & 5,1 & $\mathrm{nc}$ \\
Pseudomonas sp. & 4,1 & $\mathrm{nc}$ \\
Bactérias lácticas & & \\
\hline
\end{tabular}

a Fonte: Brasil (2001)

${ }^{b}$ Fonte: São Paulo (1978)

UFC = unidade formadora de colônia

$\mathrm{NMP}$ = número mais provável

$\mathrm{nc}=$ nada consta

O efeito de incluir oxigênio em atmosferas enriquecidas $\operatorname{com} \mathrm{CO}_{2}$ também é confuso. Wimpfhimer et al. (1990), mostraram que o crescimento foi induzido quando oxigênio foi adicionado a atmosferas onde era previamente suprimido, ou seja, adição de $5 \%$ de $\mathrm{O}_{2}\left(\mathrm{CO}_{2} / \mathrm{O}_{2} / \mathrm{N}_{2}, 72,5: 5: 22,5\right)$ em atmosfera anaeróbica $\left(\mathrm{CO}_{2} / \mathrm{O}_{2} / \mathrm{N}_{2}, 75: 0: 25\right)$ induziu o crescimento de Listeria monocytogenes. Em contraste, nenhuma diferença foi observada no crescimento de $L$. monocytogenes em carne suina a $4^{\circ} \mathrm{C}$ embalada em condições anaeróbicas $\left(\mathrm{CO}_{2} / \mathrm{O}_{2} / \mathrm{N}_{2}, 40: 0: 60\right)$ ou aeróbicas $\left(\mathrm{CO}_{2} / \mathrm{O}_{2} / \mathrm{N}_{2}, 40: 10: 50\right)$.

Outros autores (Mano et al., 1995) não detectaram crescimento em carne suína ( $\mathrm{pH} 5,3$ ) a1 ou $7^{\circ} \mathrm{C}$ ou em carne de peru a $1^{\circ} \mathrm{C}$ empalada em atmosferas com $\mathrm{CO}_{2} / \mathrm{O}_{2}$ (20:80 ou 40:60), enquanto que o crescimento foi observado em carne de peru nessas atmosferas a $7^{\circ} \mathrm{C}$. Resultados similares têm sido descritos para atmosferas de $100 \% N_{2}$. Esses resultados, como previamente mencionados, indicam a importância do 
$\mathrm{pH}$ da carne, desde que o crescimento foi observado em carne de vaca embalada a vácuo a $7^{\circ} \mathrm{C}$ em pH 5,8 mas não em pH 5,6.

Mano et al. (1995) mediram os valores (em grama) da microbiota em carne suína e de peru embalados em atmosfera modificada e concluíram que este era maior para Listeria do que para outra microbiota. Similarmente, esses valores diminuiram conforme a concentração de $\mathrm{CO}_{2}$ aumentou, indicando por isso o efeito inibidor do $\mathrm{CO}_{2}$.

Como houve a presença de Listeria monocytogenes na matéria-prima, procedeu-se a análise de deteç̧ão deste microrganismo nos dias 5 e 11 de armazenamento, para descartar a hipótese da sua existência durante o estudo da vida útil (Tabela 3). Os resultados foram negativos para ambos os dias de armazenamento, mostrando a eficiência dos 3 tratamentos e das condições de anaerobiose na inibição do desenvolvimento deste microrganismo no presente estudo.

Tabela 3. Efeito dos tratamentos estudados, $100 \% \mathrm{CO}_{2}$, mistura e vácuo, na inibição do desenvolvimento de Listeria monocytogenes em bisteca suína armazenada a $0+3^{\circ} \mathrm{C}$

\begin{tabular}{llll}
\hline \multicolumn{3}{c}{ Listeria monocytogenes } \\
\hline Dia & $100 \% \mathrm{CO}_{2}$ & Mistura & Vácuo \\
0 & Presença & Presença & presença \\
5 & Ausência & Ausência & ausência \\
11 & Ausência & Ausência & ausência \\
\hline
\end{tabular}

$O$ efeito do $\mathrm{CO}_{2}$ no crescimento e sobrevivência de $L$. monocytogenes não está claro. Hart et al. (1991) relatam que este microrganismo não se desenvolve em carne de frango a 1 e $6^{\circ} \mathrm{C}$, carne de vaca a $5^{\circ} \mathrm{C}$, carne de carneiro a $5^{\circ}$ ou rosbife a $1,5^{\circ} \mathrm{C}$ embalados em atmosfera com $100 \%$ de $\mathrm{CO}_{2}$, embora o crescimento deste organismo tenha sido detectado em rosbife nesta atmosfera a $3^{\circ} \mathrm{C}$, indicando que 0 crescimento deste microrganismo não é prevenido pela ausência de oxigênio. $O$ crescimento de $L$. monocytogenes tem sido demonstrado em carne de carneiro a $5^{\circ} \mathrm{C}$ em uma atmosfera com $\mathrm{CO}_{2} / \mathrm{N}_{2}$, e em carne suina embalada em $\mathrm{CO}_{2} / \mathrm{N}_{2}(40: 60)$ a $4^{\circ} \mathrm{C}$ (Manu-Tawiah et al.,1993). Entretanto, outros autores não têm detectado crescimento 
em ausência de $\mathrm{O}_{2}$ (exceto para o estudo previamente mencionado com $100 \%$ de $\mathrm{CO}_{2}$ ) e não houve crescimento algum em carne de frango embalada em $\mathrm{CO}_{2} / \mathrm{N}_{2}$ (30:70) a $6^{\circ} \mathrm{C}$ ou a $4^{\circ} \mathrm{C}$ em uma atmosfera de $\mathrm{CO}_{2} / \mathrm{N}_{2}$ de 75:25 (Wimpfhimer et al., 1990; Hart et al., 1991).

No geral, atmosferas em que a multiplicação de L. monocytogenes é inibida não são bactericidas. Nos casos onde o decréscimo na contagem foi observado durante o armazenamento foi pouco relevante (Mano et al., 1995).

Esse dado sugere que a modificação na atmosfera não pode ser considerada como o único fator envolvido na inibição da $L$. .monocytogenes desde que mudanças na temperatura, $\mathrm{pH}$ e em cada possível competição de outra microbiota também afete o crescimento. Embalagem em atmosferas modificadas faz, por isso, não necessariamente ter um risco adicional significante de crescimento de $L$. monocytogenes em comparação a embalagem convencional em condições aeróbicas (Fernandez et al., 1995).

Os resultados das contagens de bactérias lácticas, Pseudomonas sp., enterobactérias e psicrotróficos aeróbios são apresentados nas Figuras 1, 2, 3 e 4, repectivamente, e os dados com avaliação estatística encontram-se nas Tabelas 4, 5 , 6 e 7 , respectivamente, em anexo. 


\section{Evolução da contagem de bactérias lácticas}

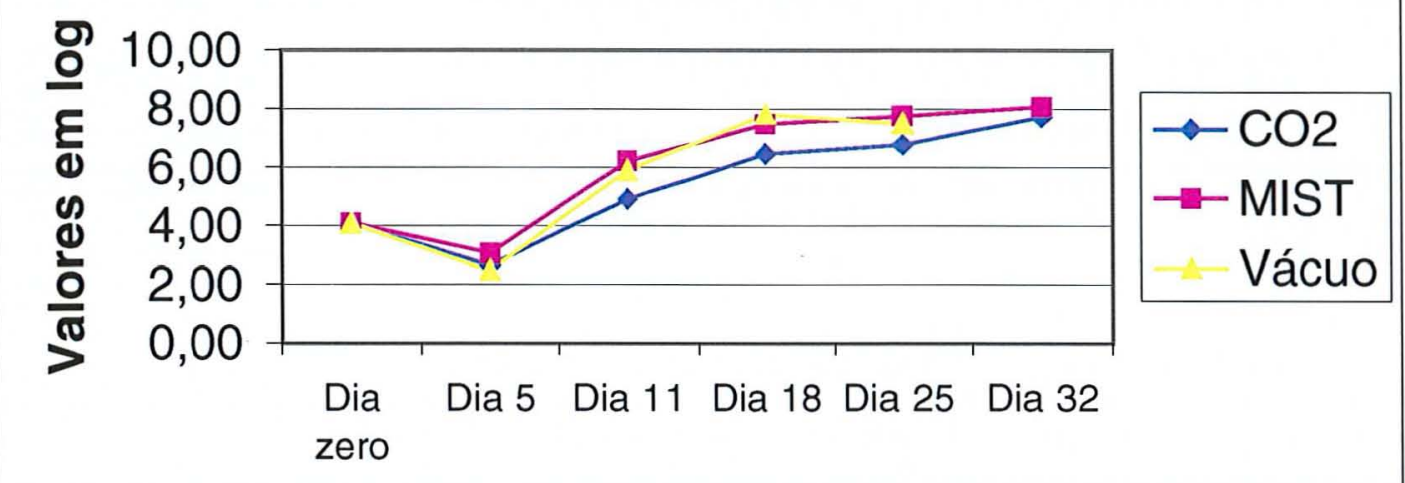

\section{Dias de armazenamento}

Figura 1 - Evolução da população de bactérias lácticas em bistecas suínas embaladas em $100 \% \quad \mathrm{CO}_{2}$, mistura $\left(50 \% \mathrm{CO}_{2} / 50 \% \mathrm{~N}_{2}\right)$ e vácuo, durante o armazenamento a $0+3^{\circ} \mathrm{C}$

Na Figura 1 observa-se o comportamento da população de bactérias lácticas na bisteca suína sob os três tratamentos estudados, onde se verifica que em todos os tratamentos a população inicial diminuiu até o $5^{\circ}$ dia de armazenamento (diminuição de 1,41 log de UFC para o tratamento com $100 \% \mathrm{CO}_{2}$, diminuição de $1,02 \log$ de UFC para o tratamento mistura e diminuição de 1,58 log de UFC para o tratamento vácuo). A partir daí, no tratamento controle (vácuo) verifica-se a que a população aumentou progressivamente de 2,5 log de UFC até 7,8 log de UFC durante 18 dias de armazenamento e estabilizou em 7,4 log de UFC ao final de sua vida útil (aos 25 dias de armazenamento), quando foi rejeitado pela equipe sensorial.

No tratamento com $100 \% \mathrm{CO}_{2}$, após um aumento de 2,67 log de UFC aos 5 dias de armazenamento para 6,79 log de UFC aos 25 dias de armazenamento, a contagem de bactérias lácticas atingiu valores de 7,71 log de UFC ao fim dos 32 dias de armazenamento.

Já com o tratamento mistura, esse aumento também foi progressivo, atingindo valores de 8,06 log de UFC ao final dos 32 dias de armazenamento. 
Segundo Kakouri \& Nychas (1994), o crescimento de alguns gêneros de bactérias lácticas pode ser favorecido se o oxigênio é disponível, além disso, as contaminações durante $O$ abate $e$ as condições da carne têm grande influência na deterioração por bactérias.

A análise estatística das contagens de bactérias lácticas (Tabela $4 \mathrm{em}$ anexo) não mostrou diferença significativa $(p \leq 0,05)$ entre os tratamentos estudados (100\% $\mathrm{CO}_{2}$, mistura e vácuo) até o $11^{\circ}$ dia de armazenamento, que, apesar disso, tendeu a uma menor média no tratamento com $100 \% \mathrm{CO}_{2}(4,91)$ em relação aos outros dois tratamentos. No $18^{\circ}$ dia de armazenamento, o tratamento com $100 \% \mathrm{CO}_{2}$ obteve menor média de contagem $(6,44)$ e foi estatisticamente diferente do tratamento vácuo $(p \leq 0,05)$, porém não foi diferente $(p \leq 0,05)$ do tratamento mistura, que não diferiu estatisticamente do tratamento vácuo $(p \leq 0,05)$. No $25^{\circ}$ dia de armazenamento, mais uma vez o tratamento com $100 \% \mathrm{CO}_{2}$ obteve a menor média de contagem de bactérias lácticas $(6,79)$ e foi estatisticamente diferente $(p \leq 0,05)$ dos tratamentos mistura e vácuo, que não diferiram estatisticamente entre si $(p \leq 0,05)$. Aos 32 dias de armazenamento, o tratamento com $100 \% \mathrm{CO}_{2}$ foi estatisticamente $(p \leq 0,05)$ mais eficiente que o tratamento mistura, porém isso não impediu as altas contagens desse microrganismo para ambos os tratamentos com gases, que alcançaram valores de $7,71 \log$ de UFC e de 8,06 log de UFC, respectivamente, para os tratamentos com $100 \% \mathrm{CO}_{2}$ e mistura, demonstrando que já estavam em avançado estagio de deterioração, conforme Bomar (1985) em seu experimento utilizando carne bovina.

Holzapfel (1998) explica que, dentre a população microbiana tipicamente encontrada na carne, um número de bactérias gram-positivas tem uma forte vantagem competitiva com respeito a embalagem a vácuo e as bactérias lácticas em particular, freqüentemente caracterizam uma típica associação da deterioração juntamente com seus produtos.

Segundo McMullen \& Stles (1994), as bactérias gram-positivas (principalmente as bactérias lácticas) constituem apenas uma menor proporção da típica microbiota psicrotrófica na carne embalada em ar. A embalagem a vácuo e refrigeração a $0-1^{\circ} \mathrm{C}$, no entanto, seletivamente promoverá um aumento no número de bactérias lácticas para mais de $5 \times 10^{7} \mathrm{UFC} / \mathrm{cm}^{2}$. A temperatura de estocagem também influencia a mudança da população dentre as bactérias lácticas, com 
Carnobacterium sp dominando em carne suína armazenada em $100 \% \mathrm{CO}_{2}$ a $-1,5^{\circ} \mathrm{C}$, e Lactobacillus sp homofermentativo a $4-7^{\circ} \mathrm{C}$.

De acordo com Egan (1983), na presença de $\mathrm{CO}_{2}$ e sob condições reduzidas de $\mathrm{O}_{2}$, a taxa de crescimento de bactérias lácticas é reduzida e a vida útil da carne embalada a vácuo pode atingir 10-12 semanas a $0^{\circ} \mathrm{C}$, diferente do resultado encontrado no presente estudo, ode o tratamento vácuo atingiu vida útil entre 11 e 18 dias.

As interações microbianas mais importantes na carne são geralmente consideradas no contexto da deterioração (por exemplo, acidificação, proteólise/putrefação, etc) e potenciais conseqüências à saúde (por exemplo, produção de toxinas, aminas biogênicas, etc). A presença de bactérias lácticas pode ser desejável em carne embalada a vácuo e sua presença conduz a um controle natural de patógenos e deterioração putrefativa, através da produção de ácido lático e de outros metabólitos antimicrobianos, e pela competição, etc (Holzapfel, 1998).

Nattress \& Jeremiah (2000) explicam que os lactobacilos podem dominar a microbiota de embalagens com ATM com baixo teor de oxigênio ou a vácuo, mas não é uma conseqüência grave, em curtos períodos de estocagem. $O$ desenvolvimento precoce de odores estranhos coincide com a alteração da microbiota lática de nãoacidúrica para acidúrica (Seideman \& Durland, 1983). 


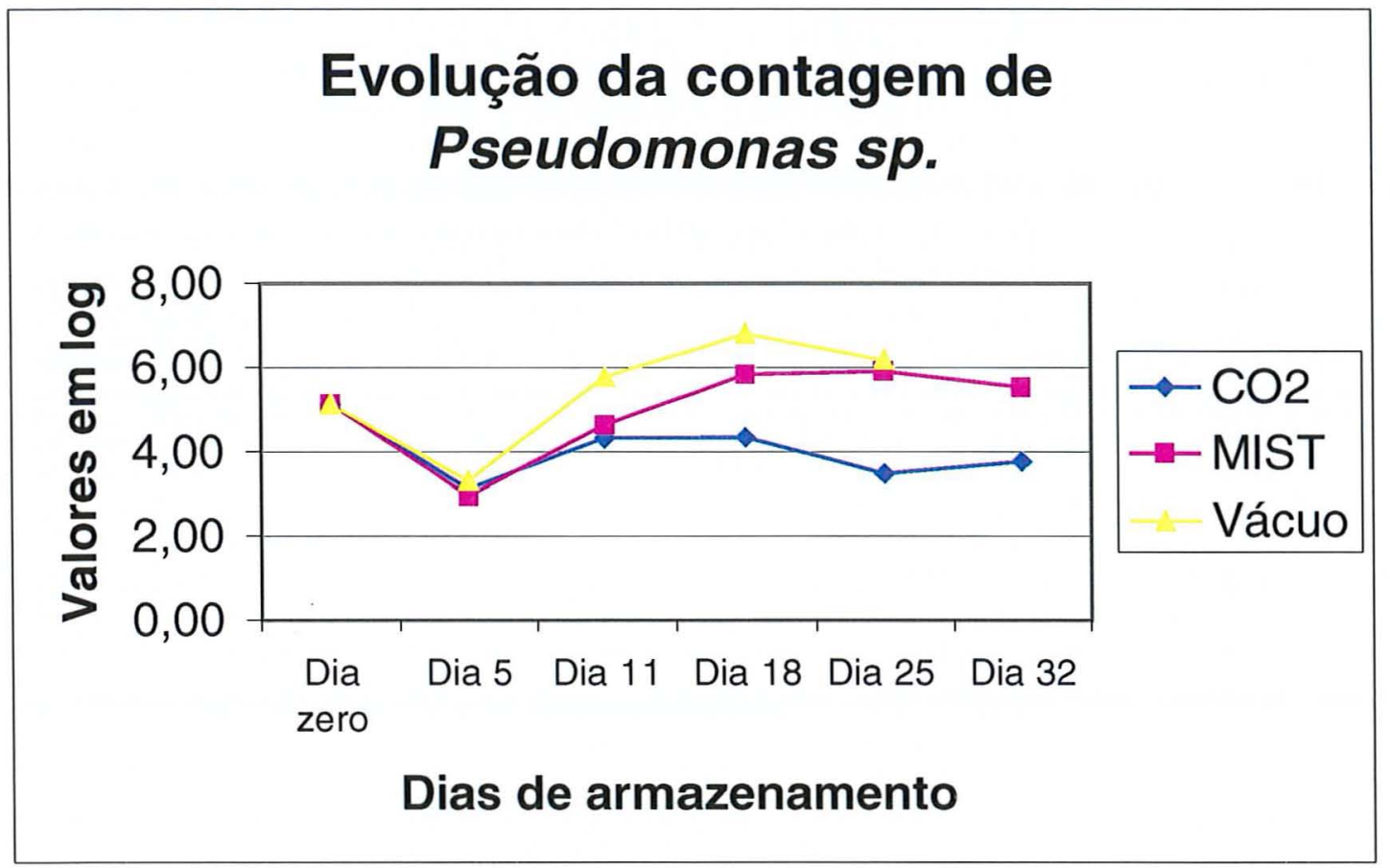

Figura 2 - Evolução da população de Pseudomonas sp.em bistecas suínas embaladas em $100 \% \mathrm{CO}_{2}$, mistura $\left(50 \% \mathrm{CO}_{2} / 50 \% \mathrm{~N}_{2}\right)$ e vácuo, durante o armazenamento a $0+3^{\circ} \mathrm{C}$

Na Figura 2, observa-se a evolução das contagens de Pseudomonas sp.em bisteca suína armazenada em atmosfera modificada. Os três tratamentos estudados diminuíram as contagens iniciais de Pseudomonas sp.(diminuição de 2,02, 2,2 e 1,83 log de UFC para os tratamentos com $100 \% \mathrm{CO}_{2}$, mistura e vácuo, respectivamente, conforme Tabela $5 \mathrm{em}$ anexo), demonstrando que todos foram eficientes na redução das contagens desse microrganismo na matéria-prima utilizada. A partir do $5^{\circ}$ dia de armazenamento, o tratamento controle (vácuo) apresentou um crescimento progressivo até $\circ 18^{\circ}$ dia de armazenamento, com um aumento de 3,49 log de UFC durante esse período, atingindo um valor médio de 6 log de UFC aos 25 dias de armazenamento. Segundo Enfors et al. (1979), a embalagem a vácuo permite o crescimento desse microrganismo, assim como foi observado no presente estudo.

No tratamento com $100 \% \mathrm{CO}_{2}$, houve um aumento de $1,2 \log$ de UFC do $5^{\circ}$ dia de armazenamento até o $11^{\circ}$ dia de armazenamento, mantendo-se estável até o $18^{\circ}$ dia de armazenamento, declinando $0,87 \log$ de UFC aos 25 dias de 
armazenamento e novamente aumentando aos 32 dias, quando atingiu contagens de $4,84 \log$ de UFC, sendo o tratamento que apresentou a menor contagem final deste microrganismo.

No tratamento mistura, houve um crescimento progressivo do $5^{\circ}$ dia até 0 $18^{\circ}$ dia de armazenamento (aumento de $2,9 \log$ de UFC), estabilizando-se até o $25^{\circ}$ dia, quando retornou a crescer, resultando num valor médio final de 6,74 log de UFC aos 32 dias de armazenamento.

No experimento feito por Daniels et al (1985), uma atmosfera contendo $70 \%$ de $\mathrm{CO}_{2}$ dobrou o tempo de geração das Pseudomonas sp. Já McMullen \& Stilles (1991) fizeram um estudo com carne bovina em atmosfera modificada e observaram um crescimento limitado de Pseudomonas sp.nos tratamentos utilizando $\mathrm{CO}_{2}$ a $-1^{\circ} \mathrm{C}$.

Com relação à análise estatística (Tabela $5 \mathrm{em}$ anexo), a contagem de Pseudomonas sp. não demonstrou diferença estatística $(p \leq 0,05)$ entre os tratamentos estudados até $\circ 11^{\circ}$ dia de armazenamento, que no entanto teve uma tendência a ser mais elevada ( $>1 \log$ UFC) no tratamento a vácuo com relação aos tratamentos com gás ( $100 \% \mathrm{CO}_{2}$ e mistura), o que corrobora com Enfors et al. (1979) e McMullen \& Stiles (1991). No $18^{\circ}$ dia de armazenamento, o tratamento com $100 \% \mathrm{CO}_{2}$ obteve menor média de contagem desse microrganismo $(4,34)$, sendo aproximadamente 2 log UFC menor que dos outros dois tratamentos estudados (mistura e vácuo), que apesar de não apresentarem diferença estatística $(p \leq 0,05)$ entre si, demonstrou uma certa tendência do tratamento mistura ser mais eficiente que o vácuo, pois este último apresentou contagem 1 log UFC maior que o tratamento mistura. No $25^{\circ}$ dia de armazenamento, o tratamento com $100 \% \mathrm{CO}_{2}$ foi mais eficiente (média de 3,47 ) que os demais tratamentos $(p \leq 0,05)$, sendo aproximadamente 2 log UFC menor que os tratamentos mistura e vácuo, que não apresentaram diferença estatística entre si $(p \leq 0,05)$. Aos 32 dias de armazenamento, o tratamento com $100 \% \mathrm{CO}_{2}$ foi mais eficiente (média 4,84$)$ que o tratamento mistura $(p \leq 0,05)$ o qual apresentou uma contagem de aproximadamente 2 log UFC maior que o tratamento com $100 \% \mathrm{CO}_{2}$.

No estudo realizado por Nissen et al. (1996), após 5 semanas de armazenamento de carne bovina a $2^{\circ} \mathrm{C}$ e $6^{\circ} \mathrm{C}$, o crescimento de Pseudomonas sp. foi significativamente menor $(p \leq 0,05)$ nas amostras do tratamento com $\mathrm{CO}_{2}$ do que no vácuo, assim como foi observado no presente estudo. 


\section{Evolução da contagem de enterobactérias}

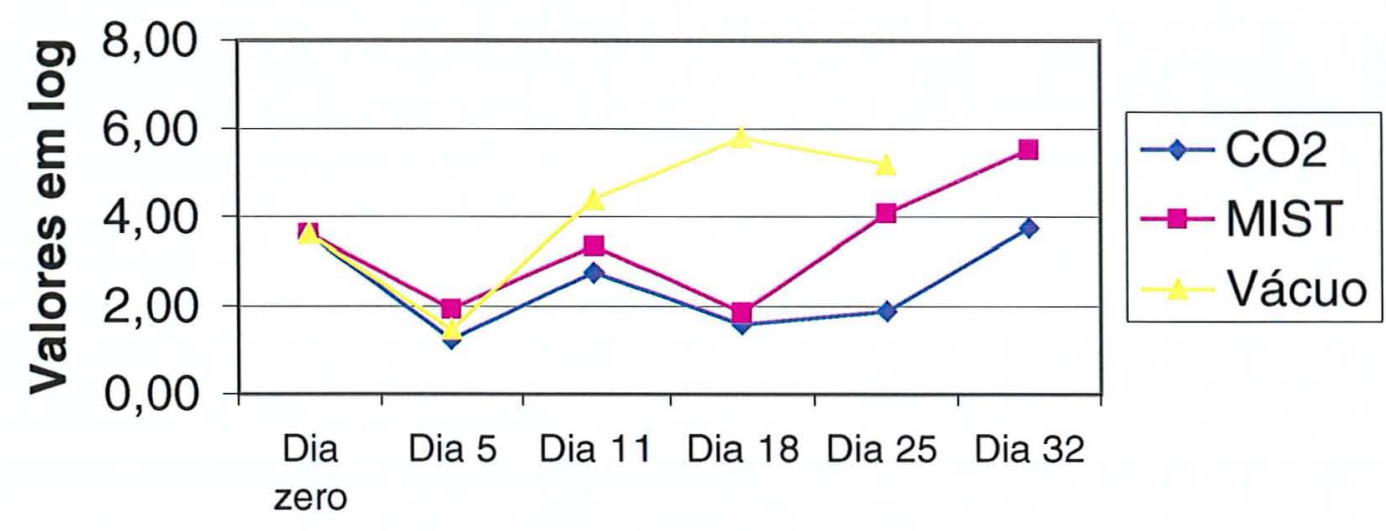

Dias de armazenamento

Figura 3 - Evolução da população de enterobactérias em bistecas suínas embaladas em $100 \% \quad \mathrm{CO}_{2}$, mistura $\left(50 \% \mathrm{CO}_{2} / 50 \% \mathrm{~N}_{2}\right)$ e vácuo, durante o armazenamento a $0+3^{\circ} \mathrm{C}$

Na Figura 3 está exposta a evolução das contagens das enterobactérias em bisteca suína armazenada em atmosfera modificada. Para os três tratamentos estudados, as contagens iniciais de 3,62 log de UFC declinaram até o $5^{\circ}$ dia de armazenamento (diminuições de 2,39, 1,7 e 2,16 log de UFC para os tratamentos com $100 \% \mathrm{CO}_{2}$, mistura e vácuo, respectivamente). A partir daí, o controle (vácuo) permitiu um crescimento progressivo de 1,46 log de UFC aos 5 dias de armazenamento até 5,8 $\log$ de UFC aos 18 dias de armazenamento, finalizando com 5,2 log de UFC aos 25 dias de armazenamento, quando foi rejeitado pela equipe sensorial.

O tratamento com $100 \% \mathrm{CO}_{2}$ apresentou um aumento nas contagens do $5^{\circ}$ dia ao $11^{\circ}$ dia de armazenamento (1,52 log de UFC), com declínio até os 18 dias de armazenamento (1,58 log de UFC), mantendo-se praticamente estável até $\circ 25^{\circ}$ dia de armazenamento, quando retornou ao crescimento, culminando em 3,76 log de UFC aos 32 dias de armazenamento, apresentando a menor contagem dos três tratamentos estudados. Segundo Gill \& Penney (1988), o $\mathrm{CO}_{2}$ sendo um gás ativo, apresenta um 
desejável efeito bacteriostático e em seu estudo observaram que a utilização deste gás em alta concentração (acima de $70 \%$ ) em carne suína estocada a $1^{\circ} \mathrm{C}$ retardou, progressivamente, o desenvolvimento tanto da microbiota quanto da deterioração de enterobactérias, o que corrobora com o presente estudo.

Com relação ao tratamento mistura, este apresentou tendência semelhante de crescimento até o $18^{\circ}$ dia de armazenamento, quando começou a crescer progressivamente até os 32 dias de armazenamento, finalizando com uma contagem de $5,51 \log$ de UFC.

$\mathrm{Na}$ avaliação estatística, a contagem de enterobactérias (Figura $6 \mathrm{em}$ anexo) não demonstrou diferença significativa $(p \leq 0,05)$ entre os três tratamentos estudados $\left(100 \% \mathrm{CO}_{2}\right.$, mistura e vácuo) até $\circ 5^{\circ}$ dia de armazenamento. No $11^{\circ}$ dia de armazenamento, o tratamento com $100 \% \mathrm{CO}_{2}$ apresentou menor média $(2,75)$ e não foi estatisticamente diferente $(p \leq 0,05)$ da mistura e foi estatisticamente diferente $(p \leq 0,05)$ do tratamento vácuo (contagem maior de $1 \log$ UFC a mais que o tratamento com $\left.100 \% \mathrm{CO}_{2}\right)$, que não apresentou diferença significativa $(p \leq 0,05)$ com o tratamento mistura. No $18^{\circ}$ dia de armazenamento, o tratamento a vácuo teve contagem de enterobactérias estatisticamente maior $(5,80 ; p \leq 0,05)$ que os tratamentos com gás $\left(100 \% \mathrm{CO}_{2}\right.$ e mistura), que não diferiram estatisticamente entre si $(p \leq 0,05)$ e foram aproximadamente $3 \log$ UFC menores que o vácuo. Aos 25 dias de armazenamento o tratamento com $100 \% \mathrm{CO}_{2}$ obteve a menor contagem de enterobactérias e foi estatisticamente diferente $(p \leq 0,05)$ dos tratamentos mistura e vácuo, que também foram significativamente diferentes $(p \leq 0,05)$ entre si. A contagem do vácuo foi 3 log UFC maior mais elevada que a do tratamento com $100 \% \mathrm{CO}_{2}$ e a contagem do tratamento mistura foi aproximadamente 2,5 log UFC maior que o tratamento com $100 \% \mathrm{CO}_{2}$, mostrando que a maior concentração deste gás influenciou efetivamente a evolução do crescimento deste microrganismo $(p \leq 0,05)$. No $32^{\circ}$ dia de armazenamento, apesar da não existência de diferença estatística $(p \leq 0,05)$ entre os tratamentos com $100 \% \mathrm{CO}_{2}$ e mistura, o tratamento com a maior concentração do $\mathrm{CO}_{2}$ demonstrou uma tendência a ser mais eficiente, pois apresentou contagem de aproximadamente 2 log UFC inferior ao da mistura. Isso pode demonstrar a sensibilidade das enterobactérias a grandes concentrações de $\mathrm{CO}_{2}$, em conjunto com as baixas concentrações de $\mathrm{O}_{2}$ apresentadas nesse estudo. 
Quanto a contagem de enterobactérias ficou evidenciado que as atmosferas com gases $\left(100 \% \mathrm{CO}_{2}\right.$ e $\left.50 \% \mathrm{CO}_{2} / 50 \% \mathrm{~N}_{2}\right)$ demonstraram maior eficiência do que o vácuo nos períodos de estocagem refrigerada considerados, principalmente 0 tratamento com $100 \% \mathrm{CO}_{2}$, o qual obteve as menores contagens $(1,58,1,8$ e 3,76 log UFC/g; $p \leq 0,05)$, respectivamente no $18^{\circ}, 25^{\circ}$ e $32^{\circ}$ dias de estocagem. Buys et al. (1994) e Gill \& Harrison (1989) também constataram a redução das enterobactérias em carne suína em função da atmosfera com gás.

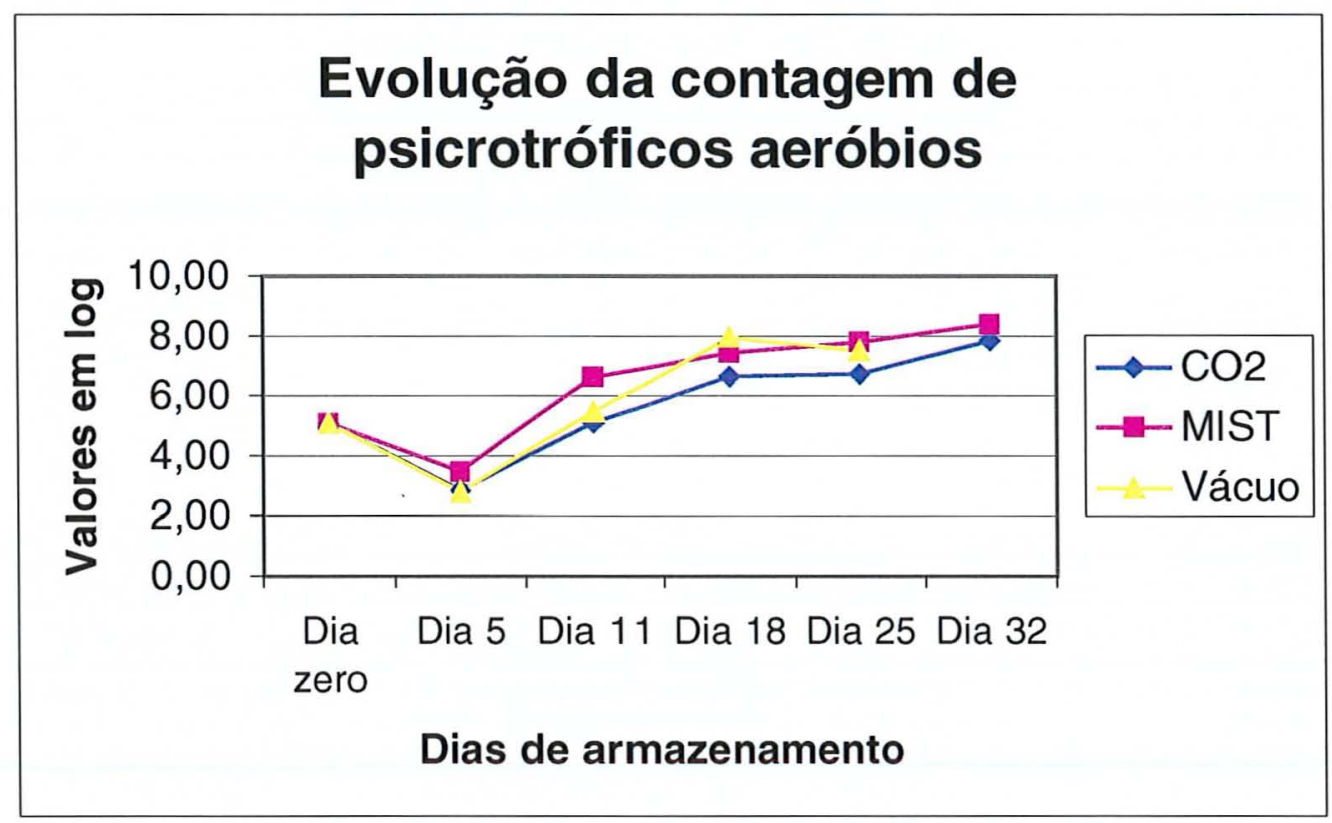

Figura 4 - Evolução da população de psicrotróficos aeróbios em bistecas suínas embaladas em $100 \% \mathrm{CO}_{2}$, mistura $\left(50 \% \mathrm{CO}_{2} / 50 \% \mathrm{~N}_{2}\right)$ e vácuo, durante o armazenamento a $0+3^{\circ} \mathrm{C}$

Na Figura 4 observa-se o comportamento da população de microrganismos psicrotróficos aeróbios nos três tratamentos do presente estudo. No tratamento controle (vácuo), após uma queda inicial de 2,3 log de UFC até $\circ 5^{\circ}$ dia de armazenamento, apresentou um aumento contínuo de 2,8 log de UFC até 7,96 log de UFC aos 18 dias de estocagem, declinando 0,44 log de UFC aos 25 dias de armazenamento, o que pode ser atribuído às reduzidas concentrações de oxigênio no espaço livre, que inibe os microrganismos aeróbios e também às propriedades 
bacteriostáticas do $\mathrm{CO}_{2}$, o qual é inibidor deste tipo de microrganismo durante a estocagem conforme explicam Bartkowski et al. (1982).

Nos tratamentos com gases $\left(100 \% \mathrm{CO}_{2}\right.$ e mistura) a contagem nas bistecas aumentou progressivamente de 2,85 log de UFC até $6,65 \log$ de UFC aos 18 dias de armazenamento para o tratamento com $100 \% \mathrm{CO}_{2}$, manteve-se estável até os 25 dias de armazenamento (com um aumento de 0,07 log de UFC) voltando a crescer, atingindo $7,86 \log$ de UFC aos 32 dias de armazenamento, enquanto que, no tratamento mistura, houve um progressivo aumento nas contagens até os 18 dias de armazenamento (aumento de 3,47 log de UFC aos 5 dias de armazenamento até 7,44 log de UFC aos 18 dias de armazenamento), com conseqüente estabilização nas contagens (aumento de 0,95 log de UFC) no final do experimento, com 8,39 log de UFC aos 32 dias de armazenamento.

No trabalho de Sorheim et al. (1996), a contagem inicial de microrganismos psicrotróficos em pedaços de lombo e costelas suinos, antes do armazenamento foi abaixo de $10^{2} \mathrm{UFC} / \mathrm{cm}^{2}$. Após o armazenamento, os pedaços do tratamento contendo $25 \% \mathrm{CO}_{2} / 65 \% \mathrm{~N}_{2} / 10 \% \mathrm{O}_{2}$ tiveram contagem de psicrotróficos maior que 1 log 10 unidade mais elevada que aquelas dos pedaços dos outros tratamentos. O aumento na concentração de $\mathrm{O}_{2}$ na embalagem para o tratamento com $10 \%$ de $\mathrm{O}_{2}$ durante o armazenamento poderia ser uma indicação do crescimento de bactérias aeróbicas.

Com relação às análises estatísticas dos microrganismos psicrotróficos (Figura $7 \mathrm{em}$ anexo), as contagens apresentadas pelos tratamentos não foram diferentes significativamente $(p \leq 0,05)$ até $o 11^{\circ}$ dia de armazenamento. Aos 18 dias de armazenamento, o tratamento com $100 \% \mathrm{CO}_{2}$ obteve menor média de contagem $(6,65)$ e diferiu estatisticamente $(p \leq 0,05)$ do tratamento com vácuo, porém não foi diferente significativamente $(p \leq 0,05)$ do tratamento mistura, que não diferiu estatisticamente do tratamento com vácuo $(p \leq 0,05)$. No $25^{\circ}$ dia de armazenamento, o tratamento com $100 \% \mathrm{CO}_{2}$ apresentou também a menor média de contagem $(6,72)$ e foi estatisticamente diferente $(p \leq 0,05)$ dos demais tratamentos (mistura e vácuo), que não apresentaram diferença significativa entre si $(p \leq 0,05)$. Aos 32 dias de armazenamento, a contagem de psicrotróficos foi menor no tratamento com $100 \% \mathrm{CO}_{2}$ e diferiu estatisticamente do tratamento mistura $(p \leq 0,05)$.

Assim, verifica-se que, apesar de uma ligeira estabilidade nas contagens dos microrganismos psicrotróficos aeróbios do $18^{\circ}$ dia ao $25^{\circ}$ dia de armazenamento, os 
três tratamentos estudados não impediram seu crescimento e atingiram, ao final do experimento, com 32 dias de armazenamento, valores médios de 7,86 log de UFC para o tratamento com $100 \% \mathrm{CO}_{2}$ e $8,39 \log$ de UFC para o tratamento mistura, o que já denota elevado grau de deterioração, conforme explica Franco \& Landgraf (1996). Esses resultados corroboram com o trabalho realizado por Bomar (1985) utilizando carne bovina.

Vários autores explicam que o efeito antimicrobiano de crescentes pressões parciais de $\mathrm{CO}_{2}$, reconhecido há muito tempo, usualmente resulta em contagens menores de psicrotróficos. $\mathrm{O} \mathrm{CO}_{2}$ na atmosfera da embalagem de carne marcadamente reduz psicrotolerantes e bactérias formadoras de limosidade, o que pode ser observado nos trabalhos feitos por Clark \& Lentz (1972) e Bartkowski (1982), e não ocorreu no presente estudo.

As bactérias lácticas, apesar de serem consideradas como um dos deteriorantes mais vigorosos em ambientes microaerófilos, predominaram no sistema, juntamente com psicrotróficos, o que está de acordo com Holzapfel (1998). O seu crescimento não foi restringido pelo $\mathrm{CO}_{2}$, diferente do que foi observado por Sarantopoulos et al. (2001), que relataram um crescimento lento subseqüente desses microrganismos.

Em um estudo feito por Egan \& Roberts (1987) e Jeremiah et al. (1995), é mostrado que o efeito levemente seletivo do $\mathrm{pH}$ normal do músculo post mortem varia de 5,4 a 5,8 e pode ser ampliado em combinação com outros fatores (exemplo embalagem a vácuo e temperatura de refrigeração). $O$ potencial de deterioração de carne DFD refrigerada $(\mathrm{pH}>6)$ é relatado principalmente o crescimento de algumas Enterobacteriaceae e Pseudomonas sp., que são, no entanto, inibidas pela embalagem á vácuo, uma prática que favorece o crescimento de lactobacilos.

Os resultados da qualidade microbiológica durante o período de vida útil da bisteca suína mostrados nas Figuras 1, 2, 3 e 4 e nas Tabelas 4, 5, 6 e 7 em anexo, evidenciaram que as bactérias estudadas cresceram rapidamente nas amostras de bisteca suína dos três tratamentos estudados estocados a 0 a $+3^{\circ} \mathrm{C}$. Nesta temperatura, os principais grupos de bactérias foram as bactérias lácticas $e$ as pscicrotróficas, que atingiram, ambas, uma população ao redor de $10^{8} \mathrm{UFC/g}$ aos 32 dias de armazenamento. Em contraste, as enterobactérias atingiram populações máximas ao redor de $10^{3} \mathrm{UFC/g}$ aos 32 dias de armazenamento para o tratamento 
com $100 \% \mathrm{CO}_{2}, 10^{5} \mathrm{UFC/g}$ aos 32 dias de armazenamento para o tratamento mistura e $10^{5} \mathrm{UFC/g}$ aos 25 dias de armazenamento para o tratamento vácuo. As Pseudomonas sp. atingiram populações máximas ao redor de $10^{4} \mathrm{UFC} / g$ aos 32 dias de armazenamento para o tratamento com $100 \% \mathrm{CO}_{2}, 10^{6} \mathrm{UFC} / \mathrm{g}$ aos 32 e 25 dias de armazenamento para os tratamentos mistura e vácuo, respectivamente. Isso demonstra que $\circ \quad \mathrm{CO}_{2}$ retardou $\circ$ crescimento das Enterobactérias e das Pseudomonas, porém não demonstrou o mesmo efeito para as bactérias lácticas e psicrotróficas. McMullen \& Stilles (1991) também observaram tendência semelhante ao presente estudo. Os resultados indicam ainda que o controle (vácuo) não limitou o desenvolvimento das bactérias avaliadas com a mesma eficiência dos tratamentos com gás, o que está em conformidade com o trabalho de Shay \& Egan (1986).

\subsection{Caracterização das embalagens}

As caracteristicas da embalagem Masterpack utilizada no acondicionamento das bistecas suínas bem como as taxas de permeabilidade aos gases $\left(\mathrm{TPO}_{2}\right)$ são apresentadas no Quadro 1.

\begin{tabular}{|cc|}
\hline Características & Embalagem secundária \\
\hline Composição & PEBD/EVOH \\
Espessura total & 100 \\
$(\mu \mathrm{m})$ & \\
$\mathrm{TPO}_{2} \mathrm{~cm}^{3}(\mathrm{CNTP}) / \mathrm{m}^{2} /$ dia & 1.87 \\
$1 \mathrm{~atm}, 23^{\circ} \mathrm{C}$ e $0 \%$ UR & \\
\hline
\end{tabular}

Quadro 1 - Características da embalagem secundária utilizada

Os resultados de $\mathrm{TPO}_{2}$ estão dentro dos valores recomendados na literatura, ou seja, $\mathrm{TPO}_{2}$ inferior a $2 \mathrm{~cm}^{3} / \mathrm{m}^{2} / \mathrm{dia} / \mathrm{atm}$ (Rizvi, 1981). 
Com relação às embalagens primárias utilizadas no presente estudo, estas apresentaram taxas de permeabilidade ao oxigênio e ao dióxido de carbono, conforme é mostrado no Quadro 2.

$\mathrm{O}$ resultado de $\mathrm{TPO}_{2}$ das embalagens primárias utilizadas nesse estudo foi acima do valor mínimo de $5000 \mathrm{~cm}^{3}$ (CNTP) $/ \mathrm{m}^{2} /$ dia a $23^{\circ} \mathrm{C}$, para permitir suficiente reoxigenação da superficie da carne (Taylor, 1985).

\begin{tabular}{|cc|}
\hline Caracteristicas & Embalagem primária \\
\hline $\mathrm{TPO}_{2} \mathrm{~cm}^{3}$ (CNTP)/m $/$ dia & 12.717 \\
$1 \mathrm{~atm}, 23^{\circ} \mathrm{C}$ e $0 \%$ UR & \\
$\mathrm{TPCO}_{2} \mathrm{~cm}^{3}$ (CNTP)/m $/$ dia & 49.338 \\
$1 \mathrm{~atm}, 23^{\circ} \mathrm{C}$ e $0 \%$ UR & \\
\hline
\end{tabular}

Quadro 2 - Taxas de permeabilidade ao $\mathrm{O}_{2}$ e $\mathrm{CO}_{2}$ da embalagem primária utilizada

$\mathrm{O}$ resultado de $\mathrm{TPCO}_{2}$ das embalagens primárias utilizadas nesse estudo foi de $49.338 \mathrm{~cm}^{3}$ (CNTP) $/ \mathrm{m}^{2} /$ dia a $25^{\circ} \mathrm{C}$ a seco e $1 \mathrm{~atm}$.

Essas taxas determinaram a velocidade de passagem do $\mathrm{CO}_{2}$ da atmosfera modificada da embalagem secundária (Masterpack) para dentro da embalagem primária, para exercer sua função bacteriostática. Assim como após a abertura da embalagem Masterpack determinaram a passagem do $\mathrm{O}_{2}$ pela embalagem primária para a oxigenação do pigmento, durante a exposição ao ar.

\subsection{Análise da composição gasosa do espaço livre}

As concentrações de $\mathrm{CO}_{2}$ e de $\mathrm{O}_{2}$ residual no espaço-livre das embalagens Masterpack injetadas com $100 \% \mathrm{CO}_{2}$ e $50 \% \mathrm{CO}_{2} / 50 \% \mathrm{~N}_{2}$ são ilustradas nas Figuras 5 e 6 e nas Tabelas 8 e 9 em anexo. 


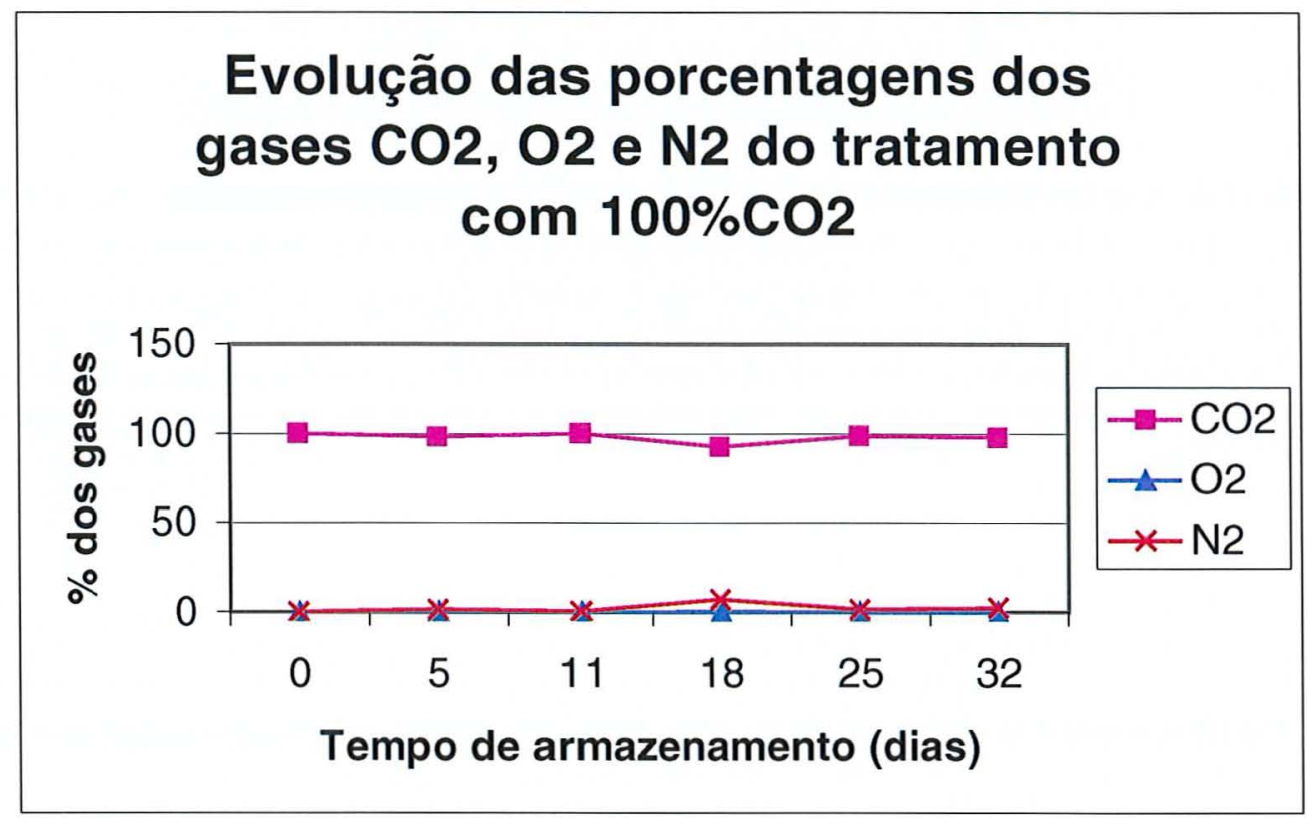

Figura 5 - Evolução das porcentagens de $\mathrm{CO}_{2}, \mathrm{O}_{2}$ e $\mathrm{N}_{2}$ do espaço-livre dos Masterpacks do tratamento com $100 \% \mathrm{CO}_{2}$ durante o estudo da vida útil da bisteca suína armazenada a $0+3^{\circ} \mathrm{C}$

Pode-se observar na Figura 5 que as concentrações de $\mathrm{CO}_{2}, \mathrm{~N}_{2}$ e de $\mathrm{O}_{2}$ não variaram durante o período de armazenamento para o tratamento com $100 \% \mathrm{CO}_{2}$ (e os dados com análise estatística podem ser observados na Tabela $8 \mathrm{em}$ anexo), mostrando que o acondicionamento estava bem controlado.

No trabalho realizado por Sorheim et al. (1995), quando, no espaço livre de embalagens de carne em atmosfera com baixo teor de oxigênio e $100 \%$ de dióxido de carbono, houve $0,5 \%$ de oxigênio, depois de fechada a embalagem, não houve residual de oxigênio depois de 5 dias de estocagem e a concentração de dióxido de carbono foi reduzida de 98 para $90 \%$.

Relatos de como a composição do gás muda durante o armazenamento de cortes suínos em embalagens com atmosfera modificada são limitados e conflitantes. Seideman et al. (1980), demonstraram que a concentração de $\mathrm{CO}_{2}$ diminuiu durante o armazenamento de cortes cárneos suínos em embalagens com atmosfera modificada a $2^{\circ} \mathrm{C}$ com mistura de gases de 20 ou $40 \%$ de $\mathrm{CO}_{2}$ com 5 a $10 \%$ de $\mathrm{O}_{2}$. No entanto, Spahl et al. (1981) descobriram que níveis de $\mathrm{CO}_{2}$ aumentaram durante $\mathrm{O}$ armazenamento deste tipo de corte em embalagem com atmosfera modificada. 
Segundo Sorheim et al. (1996), as concentrações iniciais de $\mathrm{CO}_{2}$ após o selamento das embalagens foi menor do que o esperado, baseado nas especificações dos gases, pois no tratamento com $50 \% \mathrm{CO}_{2} / 50 \% \mathrm{~N}_{2}$, que inicialmente teve $49 \%$ de $\mathrm{CO}_{2}$, teve valor final de $43 \% \mathrm{CO}_{2}$. Isso pode ser explicado pela solubilidade do $\mathrm{CO}_{2}$ na carne (Gill, 1988).

Aumentos na concentração de $\mathrm{CO}_{2}$ durante a estocagem podem resultar de uma diminuição da solubilidade de $\mathrm{CO}_{2}$ no tecido cárneo a temperaturas maiores, que resulta em um aumento do $\mathrm{CO}_{2}$ na atmosfera (Daun et al., 1971; Gill, 1988). O $\mathrm{CO}_{2}$ nas embalagens com produtos cárneos também pode aumentar devido ao metabolismo microbiano, por exemplo, Enterobacteriaceae e bactérias lácticas heterofermentativas produtoras de $\mathrm{CO}_{2}$ durante o seu crescimento. É relatado que para a composição gasosa mudar como um resultado do metabolismo microbiano, uma contagem bacteriana alta ( $10^{8}$ microrganismos/g) é exigida (Gardner et al., 1967).

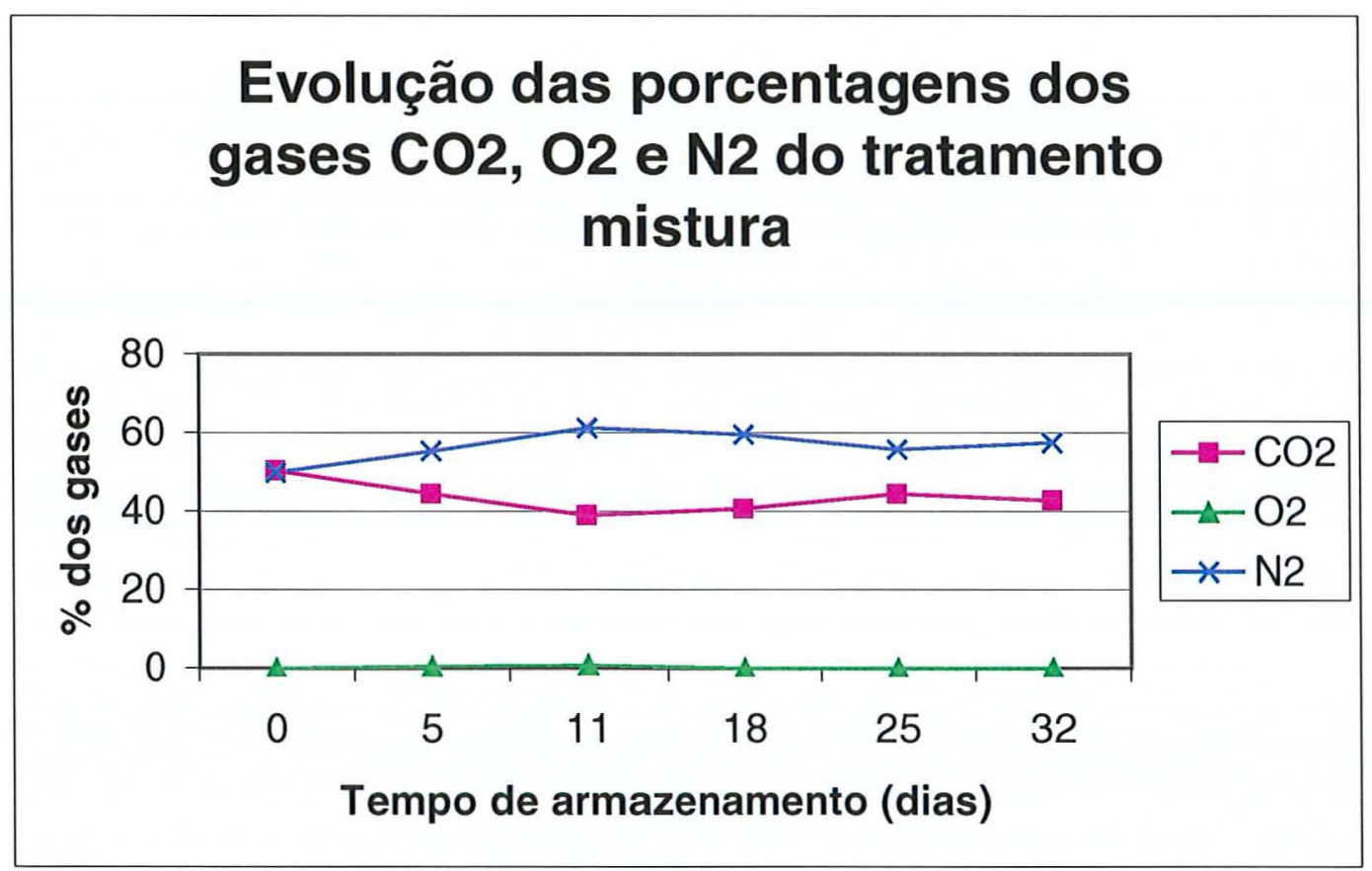

Figura 6 - Evolução das porcentagens de $\mathrm{CO}_{2}, \mathrm{O}_{2}$ e $\mathrm{N}_{2}$ do espaço-livre dos Masterpacks do tratamento mistura durante o estudo da vida útil da bisteca suína armazenada a $0+3^{\circ} \mathrm{C}$ 
Apesar da análise estatística não ter apresentado diferença significativa $(p \leq 0,05)$, conforme Tabela $9 \mathrm{em}$ anexo, pode-se observar na Figura 6 que inicialmente houve um decréscimo progressivo da concentração de $\mathrm{CO}_{2}$ até $\circ 11^{\circ}$ dia de armazenamento, o que foi provavelmente devido à solubilização deste gás na água $e$ na gordura da bisteca suina, assim como reporta Sorheim et al. (1996). A partir desta data, a concentração começa a aumentar até o $25^{\circ}$ dia de armazenamento, mantendose estável até o final do experimento (32 dias de armazenamento). $O$ aumento pode ser devido, dentre outras causas, ao metabolismo microbiano, assim como explicam Jakobsen \& Bertelsen (2002), que mostram que tanto a respiração quanto o metabolismo microbiano são responsáveis pelo consumo de $\mathrm{O}_{2}$ e produção de $\mathrm{CO}_{2}$. $\mathrm{A}$ respiração muscular ocorre principalmente nos primeiros dias após abate, decrescendo com o tempo. O metabolismo microbiano contribui principalmente para as mudanças da composição gasosa ao fim do período de vida útil, quando a atividade microbiana é alta.

A concentração de $\mathrm{O}_{2}$ residual no interior das embalagens dos dois tratamentos $\left(100 \% \mathrm{CO}_{2}\right.$ e $\left.50 \% \mathrm{CO}_{2} / 50 \% \mathrm{~N}_{2}\right)$ tiveram valores próximos a $0 \%$ no final do estudo da vida útil. Estes teores de $\mathrm{O}_{2}$ foram alcançados provavelmente devido ao acondicionamento eficiente do equipamento utilizado, além da diluição do ar ocluso entre as bistecas e entre as bistecas e a bandeja e do consumo de oxigênio pelo metabolismo de microrganismos aeróbios e taxa de respiração muscular. Essa redução foi similar à observada no trabalho realizado por Doherty \& Allen (1998) com bisteca suína utilizando $100 \% \mathrm{CO}_{2}$ e $50 \% \mathrm{CO}_{2} / 50 \% \mathrm{~N}_{2}$ a $0^{\circ} \mathrm{C}$ e por Seidemann et al. (1979) também com carne suína.

De acordo com Seidemann et al. (1979), uma redução na concentração de $\mathrm{O}_{2}$ durante a estocagem pode ser causada pela taxa de respiração muscular e metabolismo microbiano do $\mathrm{O}_{2}$, sendo maior do que a taxa de difusão no interior da embalagem.

Ocorre um decréscimo mais rápido de oxigênio, consumido pelas bactérias presentes, e pelas reações metabólicas da carne (Gill \& Molin, 1991; Gill, 1996) assim como dissolvido nos tecidos (Taylor \& MacDougall, 1973).

A concentração de oxigênio influencia a deterioração bacteriana e a preservação da aparência atrativa da carne. A concentração de oxigênio $<2 \%$ reduz a taxa de crescimento da microbiota aeróbia, primeiramente alongando a fase lag dos 
microrganismos e, a concentrações de oxigênio $<0,5 \%$ ou na sua ausência, os únicos grupos capazes de crescer a temperatura de refrigeração, são as enterobactérias e os lactobacilos (Jackson et al., 1992).

\subsection{Avaliação instrumental da cor}

Nas Figuras 7, 8 e 9 estão apresentadas as medidas de cor instrumental da bisteca suína, expressas em valores de Luminosidade $\left(L^{*}\right)$, intensidade de vermelho/verde $\left(a^{*}\right)$ e intensidade de amarelo/azul $\left(b^{*}\right)$ no sistema (CIE Lab), após 30 minutos de exposição ao ar e representam os valores das Tabelas 10, 11 e 12 em anexo.

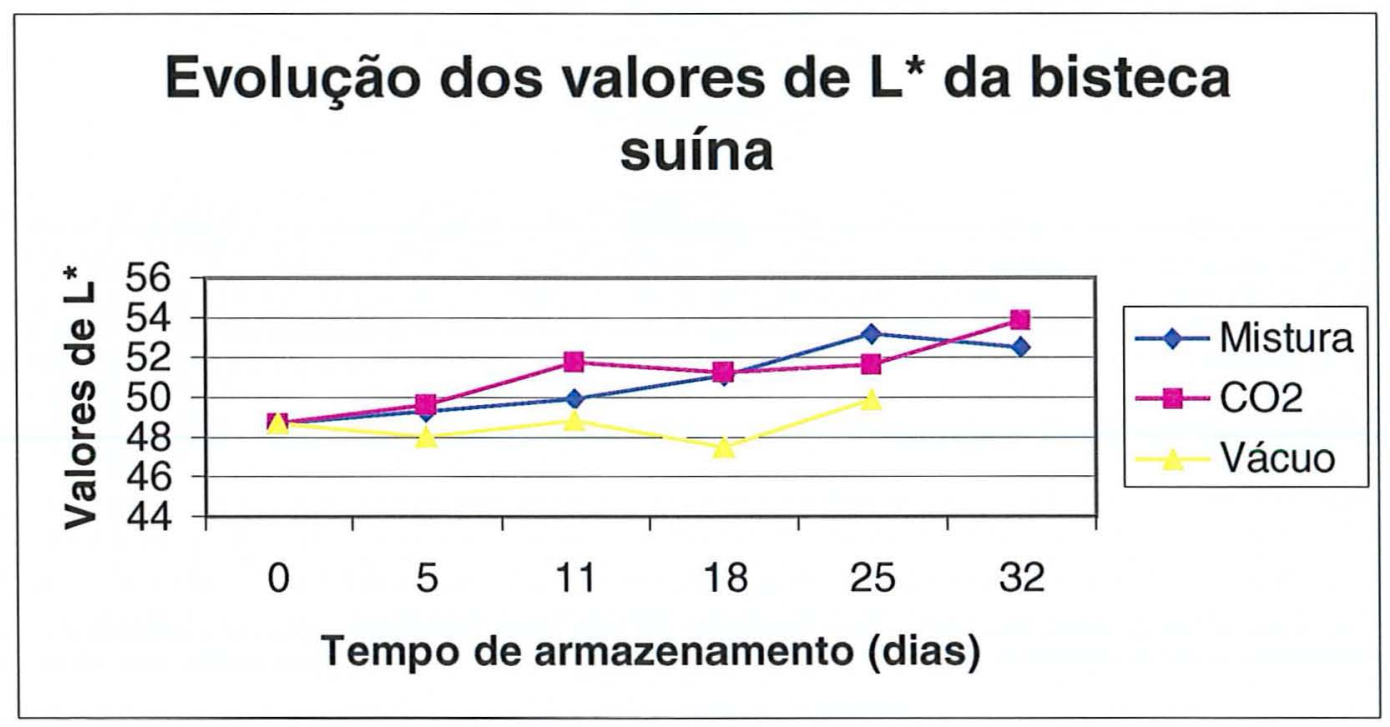

Figura 7 - Evolução dos valores de $L^{*}$ das bistecas suínas dos tratamentos com $100 \% \mathrm{CO}_{2}$, mistura e vácuo armazenadas a $0+3^{\circ} \mathrm{C}$ 


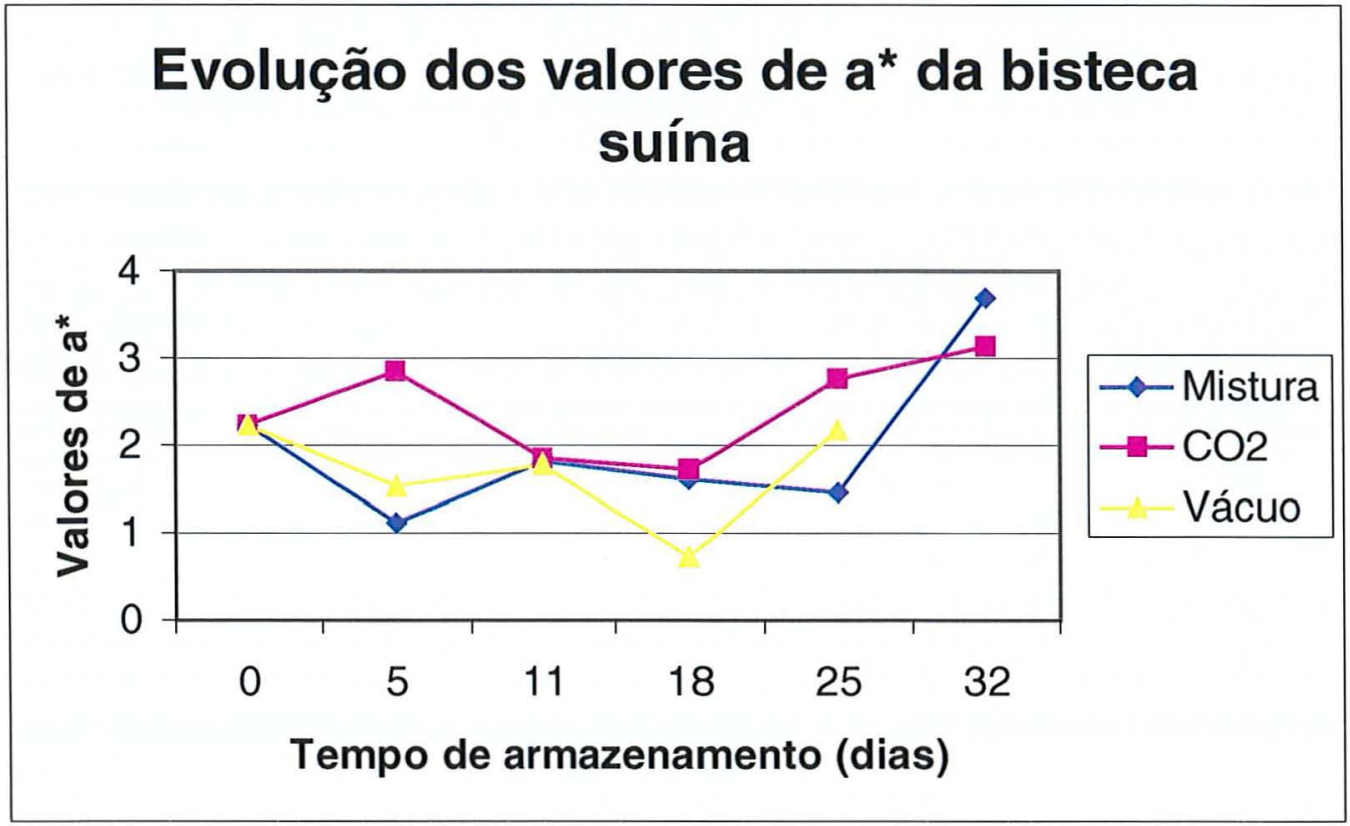

Figura 8 - Evolução dos valores de $\mathrm{a}^{*}$ das bistecas suínas dos tratamentos com $100 \% \mathrm{CO}_{2}$, mistura e vácuo armazenadas a $0+3^{\circ} \mathrm{C}$

\section{Evolução dos valores de b* da bisteca suína}

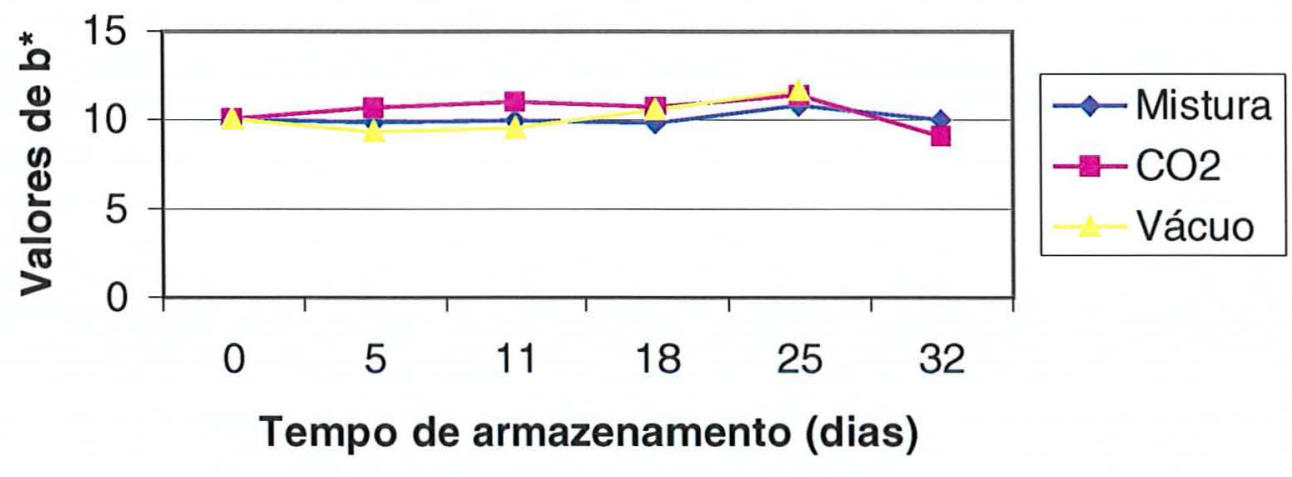

Figura 9 - Evolução dos valores de $b^{*}$ das bistecas suínas dos tratamentos com $100 \% \mathrm{CO}_{2}$, mistura e vácuo armazenadas a $0+3^{\circ} \mathrm{C}$ 
Com relação às análises estatísticas (Tabelas 10, 11 e $12 \mathrm{em}$ anexo), os valores instrumentais da cor (CIE Lab) não apresentaram diferença significativa $(p \leq 0,05)$ entre os tratamentos estudados $\left(100 \% \mathrm{CO}_{2}\right.$, mistura e vácuo) em cada dia de análise (zero, $5,11,18,25$ e 32 dias de armazenamento). Entretanto, de acordo com a Figura 7, com 5 dias de armazenamento o tratamento vácuo tendeu a menor luminosidade $\left(L^{*}=48,1\right)$ que os tratamentos com gás e também demonstrou tendência a menor valor de amarelo $\left(b^{*}=9,3\right)$. O tratamento com $100 \% \mathrm{CO}_{2}$ tendeu a ser mais vermelho que os demais tratamentos e também mais amarelo (Figuras 8 e 9 ). Doherty \& Allen (1998) observaram em seu estudo com carne suína, que o tratamento com $50 \% \mathrm{CO}_{2} / 50 \% \mathrm{~N}_{2}$ a $0^{\circ} \mathrm{C}$ apresentava maior valor de amarelo, no periodo de estocagem de 6 dias, diferente do encontrado no presente estudo aos 5 dias de armazenamento.

Com 11 dias de armazenamento, o tratamento com $100 \% \mathrm{CO}_{2}$ tendeu a apresentar maior luminosidade $\left(L^{*}=51,7\right)$ que os tratamentos mistura $\left(L^{*}=49,9\right)$ e vácuo $\left(L^{*}=48,5\right)$ e tendeu a maior valor de amarelo $\left(b^{*}=10,9\right)$ que os outros dois tratamentos estudados, onde a mistura apresentou valor $b^{*}=9,9$ e o vácuo apresentou $b^{*}=9,5$.

Aos 18 dias de armazenamento, o tratamento vácuo tendeu a ser menos luminoso e menos vermelho que os tratamentos com gás.

Com 25 dias de armazenamento, o tratamento vácuo também tendeu a ser menos luminoso que os demais tratamentos, no entanto essa tendência não ocorreu com relação aos valores de vermelho e amarelo.

Já com 32 dias de armazenamento, o tratamento com $100 \% \mathrm{CO}_{2}$ do presente estudo tendeu a apresentar maior luminosidade e a ser menos vermelho e menos amarelo que o tratamento mistura, o que está em concordância com Sorheim et al. (1996) também utilizando carne suína.

Assim, verifica-se que o tratamento com $100 \% \mathrm{CO}_{2}$ apresentou valores instrumentais de cor melhores $(p \leq 0,05)$ que os outros 2 tratamentos estudados.

\subsection{Determinação do pH}

Os valores médios de $\mathrm{pH}$ da bisteca suína acondicionada em "Masterpack" injetadas com $100 \% \mathrm{CO}_{2}, 50 \% \mathrm{CO}_{2} / 50 \% \mathrm{~N}_{2}$ e a vácuo são ilustrados na Figura $10 \mathrm{e}$ na Tabela $13 \mathrm{em}$ anexo. 


\section{Evolução do pH da bisteca suína}

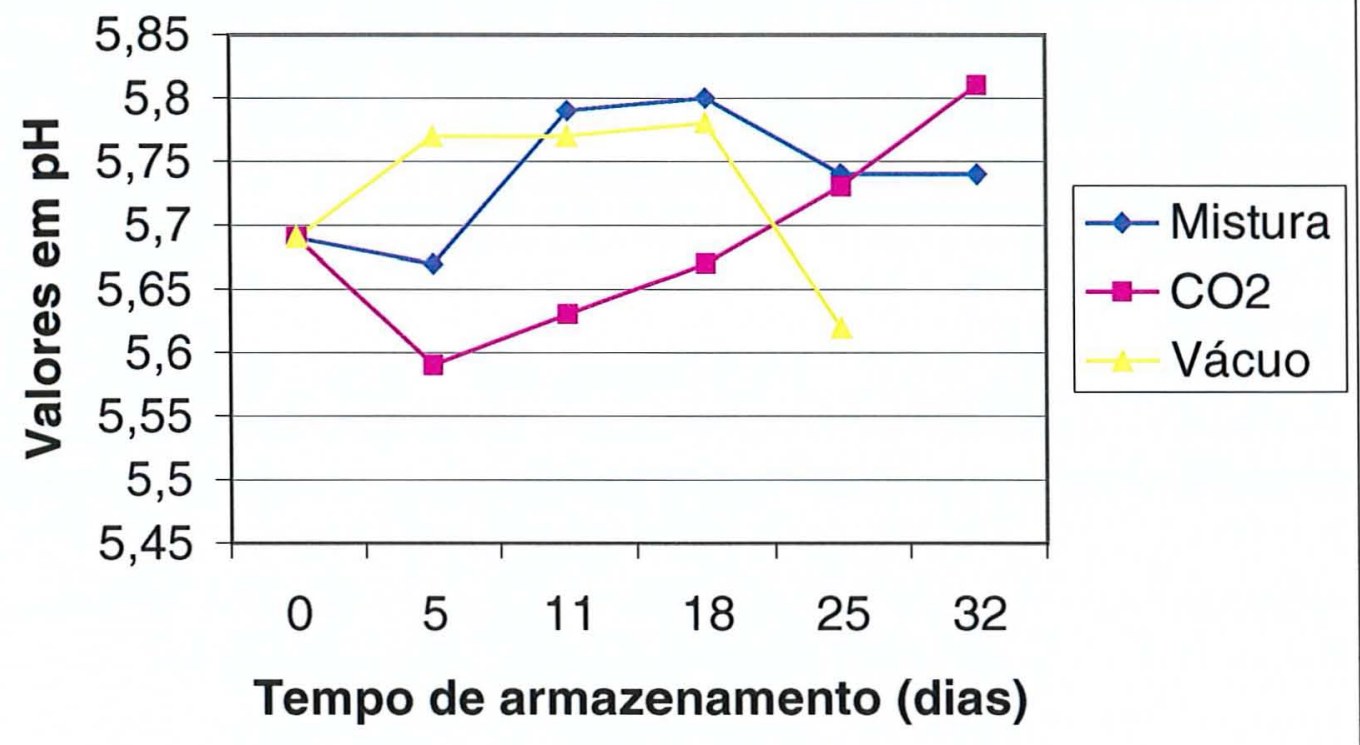

Figura 10 - Evolução do $\mathrm{pH}$ das bistecas suínas dos tratamentos com $100 \% \mathrm{CO}_{2}$, mistura e vácuo armazenadas a $0+3^{\circ} \mathrm{C}$

A Figura 10 mostra a evolução dos valores de $\mathrm{pH}$ das bistecas suínas dos tratamentos com $100 \% \mathrm{CO}_{2}$, mistura e vácuo durante o estudo da vida útil a $0+3^{\circ} \mathrm{C}$. Observa-se as diferentes tendências dos valores dos 3 tratamentos. O controle (vácuo) apresentou um aumento inicial pouco expressivo de 0,07 unidades de $\mathrm{pH}$, até $\circ 5^{\circ}$ dia de armazenamento, mantendo-se estável até o $18^{\circ}$ dia de armazenamento, diminuindo ao final do período de vida útil até pH 5,62, aos 25 dias de armazenamento, quando foi rejeitado pela equipe sensorial.

O tratamento com $100 \% \mathrm{CO}_{2}$ apresentou queda inicial do $\mathrm{pH}$ de 5,70 para 5,58 no $5^{\circ}$ dia de armazenamento, provavelmente devido a dissolução do $\mathrm{CO}_{2}$ na carne, conforme Franco \& Landgraf (1996), que explicam que as enterobactérias realizam a fermentação ácida mista ou fórmica e, os produtos desse tipo de fermentação são ácido lático, ácido succínico e ácido fórmico. Durante essa fermentação, em alguns casos, há acúmulo de ácido e o pH atinge valores inferiores a 6,0 (seis) levando, então, alguns gêneros bacterianos a produzirem a enzima 
hidrogenilase fórmica que transformará o ácido fórmico em $\mathrm{CO}_{2}+\mathrm{H}_{2}$. No presente estudo, a partir daí progressivamente até o final da vida útil, com pH 5,80 aos 32 dias de armazenamento, que pode ser decorrente do metabolismo de bactérias produtoras de compostos de aminas biogências, que apresentaram contagens altas neste experimento, assim como foi reportado por Sorheim et al. (1996) também com carne suína e, diferente do que foi observado por outros autores da literatura: a queda do $\mathrm{pH}$ nos tratamento com $\mathrm{CO}_{2}$ para as bistecas pode ser explicada pela relação linear entre a dissolução do $\mathrm{CO}_{2}$ no tecido muscular o que vai produzir uma queda no $\mathrm{pH}$, como é explicado por Jakobsen \& Bertelsen (2002). Quando altas concentrações de $\mathrm{CO}_{2}$ são usadas e quando o $\mathrm{CO}_{2}$ é absorvido subseqüentemente no tecido cárneo, o pH pode ser afetado (Bruce et al., 1996), dependendo da capacidade da carne. Rousset \& Renerre (1991) investigaram carne bovina de $\mathrm{pH}$ normal e de $\mathrm{pH}$ alto embaladas em $100 \% \mathrm{CO}_{2}$ e encontraram um grande decréscimo no $\mathrm{pH}$ da carne de alto $\mathrm{pH}$ maior do que da carne de $\mathrm{pH}$ normal, o que pode ser devido à grande solubilidade do $\mathrm{CO}_{2}$ ao elevado $\mathrm{pH}$.

$\mathrm{O} \mathrm{pH}$ do tratamento mistura decresceu ligeiramente até $05^{\circ}$ dia de armazenamento (de 5,70 para 5,67), provavelmente devido à dissolução do $\mathrm{CO}_{2}$ no meio, conforme explica Franco \& Landgraf (1996), aumentando a partir daí até 5,80 aos 11 dias de armazenamento, mantendo-se estável até o $18^{\circ}$ dia, quando começa a declinar novamente até os 25 dias de armazenamento $(5,74)$, mantendo-se estável no final do experimento, aos 32 dias de armazenamento, com valor de $\mathrm{pH}$ igual a 5,73. O aumento observado do $5^{\circ}$ dia ao $11^{\circ}$ dia de armazenamento também foi observado por Sorheim et al. (1996), utilizando carne suína em seu experimento. O decréscimo final do $\mathrm{pH}$ neste tratamento pode ter sido decorrente da maior contagem de bactérias lácticas (aproximadamente $8 \log$ de UFC, aos 32 dias de armazenamento), que acidificam o meio, diminuindo o $\mathrm{pH}$, conforme explicam Franco \& Landgraf (1996).

Com relação às análises estatísticas do pH (Tabela $13 \mathrm{em}$ anexo), os tratamentos estudados $\left(100 \% \mathrm{CO}_{2}\right.$, mistura e vácuo) não apresentaram diferença estatística $(p \leq 0,05)$ nas análises dos dias zero, $11,18,25$ e 32 de armazenamento. Somente aos 5 dias de armazenamento o tratamento com $100 \% \mathrm{CO}_{2}$ obteve menor média de $\mathrm{pH}(5,58)$ e foi estatisticamente diferente $(p \leq 0,05)$ dos demais tratamentos, que não demonstraram diferença estatística entre si $(p \leq 0,05)$. No $11^{\circ}$ dia de armazenamento houve uma tendência do tratamento com $100 \% \mathrm{CO}_{2}$ apresentar menor 
média de $\mathrm{pH}(5,63)$ com relação aos outros dois tratamentos, assim como no $18^{\circ}$ dia, onde o tratamento com $100 \% \mathrm{CO}_{2}$ também apresentou essa tendência a menor média $(5,67)$ comparado com os tratamentos mistura e vácuo. Já aos 25 dias de armazenamento, o tratamento vácuo apresentou uma tendência a menor média $(5,67)$, que pode ser explicado pela alta contagem de bactérias lácticas presentes desde os 18 dias de armazenamento ( $7 \log$ UFC), que se manteve até o final do periodo de vida útil estudado. As bactérias lácticas têm como produto final basicamente ácido lático, que acidifica o meio e conseqüentemente leva a uma diminuição do $\mathrm{pH}$ final. Com 32 dias de armazenamento, o tratamento mistura apresentou tendência a menor média de $\mathrm{pH}$ $(5,73)$ comparado com o tratamento com $100 \% \mathrm{CO}_{2}(5,80)$, provavelmente devido à presença de maior contagem de bactérias lácticas nesse tratamento.

No experimento realizado por Sarantopoulos et al. (2001), os valores de pH da superfície (média 5,62) ou do interior dos bifes (média 5,60) não variaram significativamente ao longo do armazenamento.

\section{6 Índice de TBA}

Com relação aos valores de TBA das bistecas suinas embaladas em atmosfera modificada, a Tabela $14 \mathrm{em}$ anexo explica estatisticamente o que é mostrado na Figura 11. No $5^{\circ}$ dia de armazenamento o tratamento com $100 \% \mathrm{CO}_{2}$ demonstrou a maior média $(0,048)$ e foi estatisticamente diferente $(p \leq 0,05)$ dos demais tratamentos (mistura e vácuo), que não diferiram estatisticamente entre si $(p \leq 0,05)$. Aos 11 e 18 dias de armazenamento, os valores de TBA medidos não diferiram estatisticamente $(p \leq 0,05)$ entre os 3 tratamentos estudados. Com 25 dias de armazenamento, o tratamento vácuo apresentou maior média de TBA $(0,026)$ e foi estatisticamente diferente $(p \leq 0,05)$ dos tratamentos com gases $\left(100 \% \mathrm{CO}_{2}\right.$ e mistura), que não diferiram estatisticamente entre si $(p \leq 0,05)$. Com 32 dias de armazenamento, o tratamento mistura apresentou maior média de TBA $(0,051)$ e foi estatisticamente

diferente do tratamento com $100 \% \mathrm{CO}_{2}$, o que pode ser devido ao crescimento microbiano maior nesse tratamento nesse período de armazenamento, o que pode decorrer em maior oxidação lipídica, conforme explica Franco \& Landgraf (1996). 
Observando-se os resultados apresentados, apesar das diferenças estatísticas encontradas, os valores de TBA das bistecas suínas no presente estudo foram mínimos, bem próximos ao ideal de carne suína in natura, demonstrando que o uso da atmosfera modificada não acelerou o processo de rancificação, permitindo, assim, manutenção da qualidade no produto final quanto a esse aspecto físicoquímico.

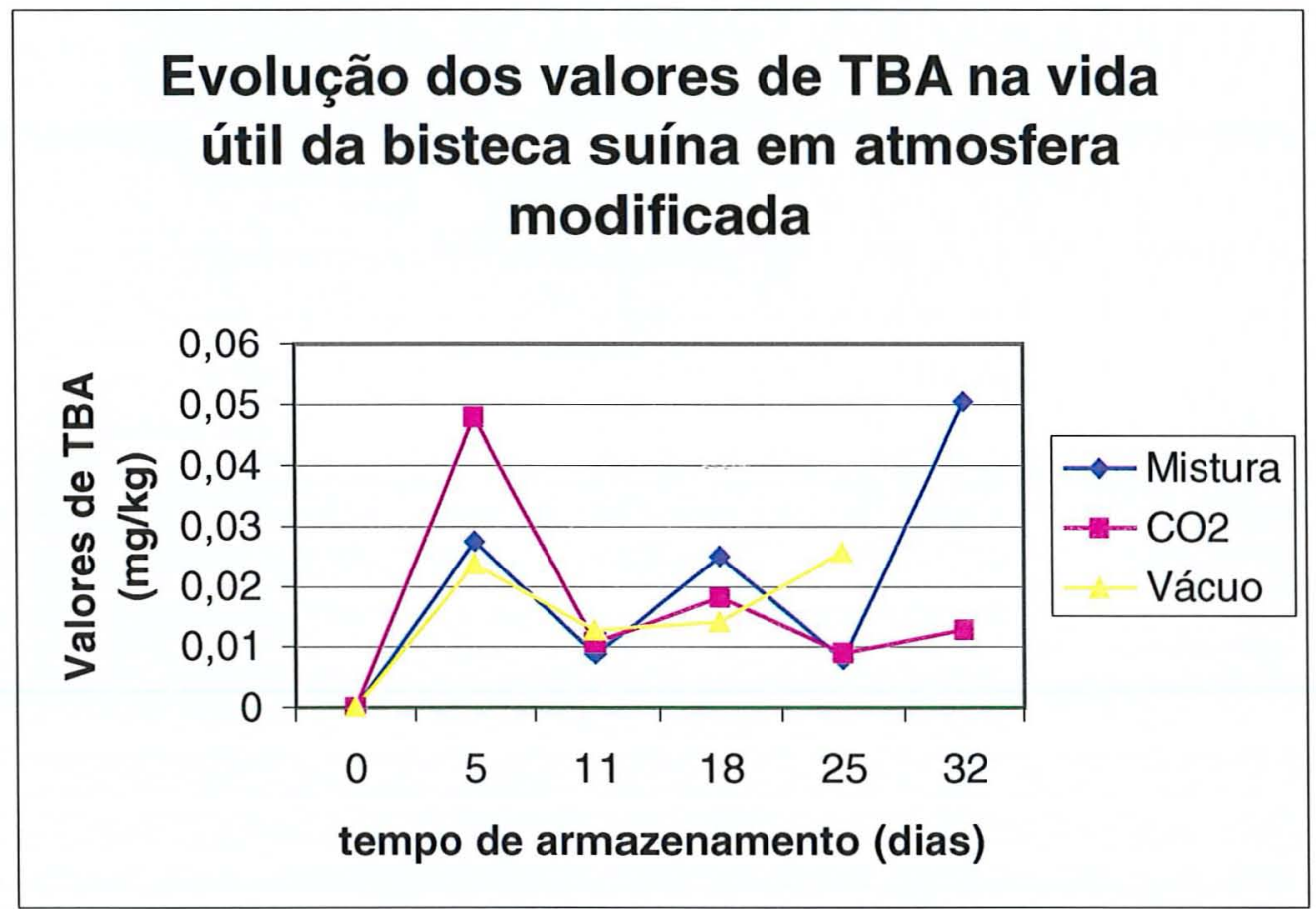

Figura 11 - Evolução dos valores de TBA das bistecas suínas dos tratamentos com $100 \% \mathrm{CO}_{2}$, mistura e vácuo armazenados a $0+3^{\circ} \mathrm{C}$

Segundo Greene (1969), as embalagens anaeróbias foram efetivas na prevenção da oxidação de lipídios e mioglobina somente quando a remoção de oxigênio e o acondicionamento foram rápidos e quando a carne continha suficiente atividade enzimática para estabelecer condições anaeróbias rapidamente reduzindo completamente qualquer metamioglobina presente, como foi observado no presente estudo. 
Com relação a oxidação, Lopez-Lorenzo et al (1980) observaram que $20 \%$ $\mathrm{CO}_{2}$ reduziu a taxa de oxidação lipidica em carne suina. Segundo Juncher et al (2001), isso é possível visto que um aumento nos niveis de $\mathrm{CO}_{2}$ resulte em um decréscimo no $\mathrm{pH}$ devido a absorção de $\mathrm{CO}_{2}$ que provavelmente tem um efeito menor na oxidação lipídica. Jeremiah \& Gibson (1997) concluiram que a despeito da alta suscetibilidade dos lipidios na carne suína, para a rancidez oxidativa, mudanças no flavor em $100 \%$ $\mathrm{CO}_{2}$ ou vácuo não seriam um problema, conquanto que não sejam utilizados filmes de baixa permeabilidade ao $\mathrm{O}_{2}$ nem tão pouco abusos de temperatura ocorram.

\subsection{Avaliação sensorial}

As Figuras 12 a 19 mostram as notas médias obtidas por dia de cada atributo sensorial de aparência ("cor marrom do músculo", "cor vermelha do músculo", "cor nominal do músculo", "cor amarela da gordura" e "cor do osso"), odor ("quantidade de odor estranho" e "tipo de odor percebido") e "qualidade geral" e as Tabelas de 15 a $22 \mathrm{em}$ anexo apresentam os valores médios desses atributos sensoriais da bisteca suína embalada em $100 \% \mathrm{CO}_{2}$, Mistura $\left(50 \% \mathrm{CO}_{2} / 50 \% \mathrm{~N}_{2}\right)$ e vácuo, durante estocagem a $0+3^{\circ} \mathrm{C}$ nos tempos zero, $5,11,18,25$ e 32 dias de armazenamento. 


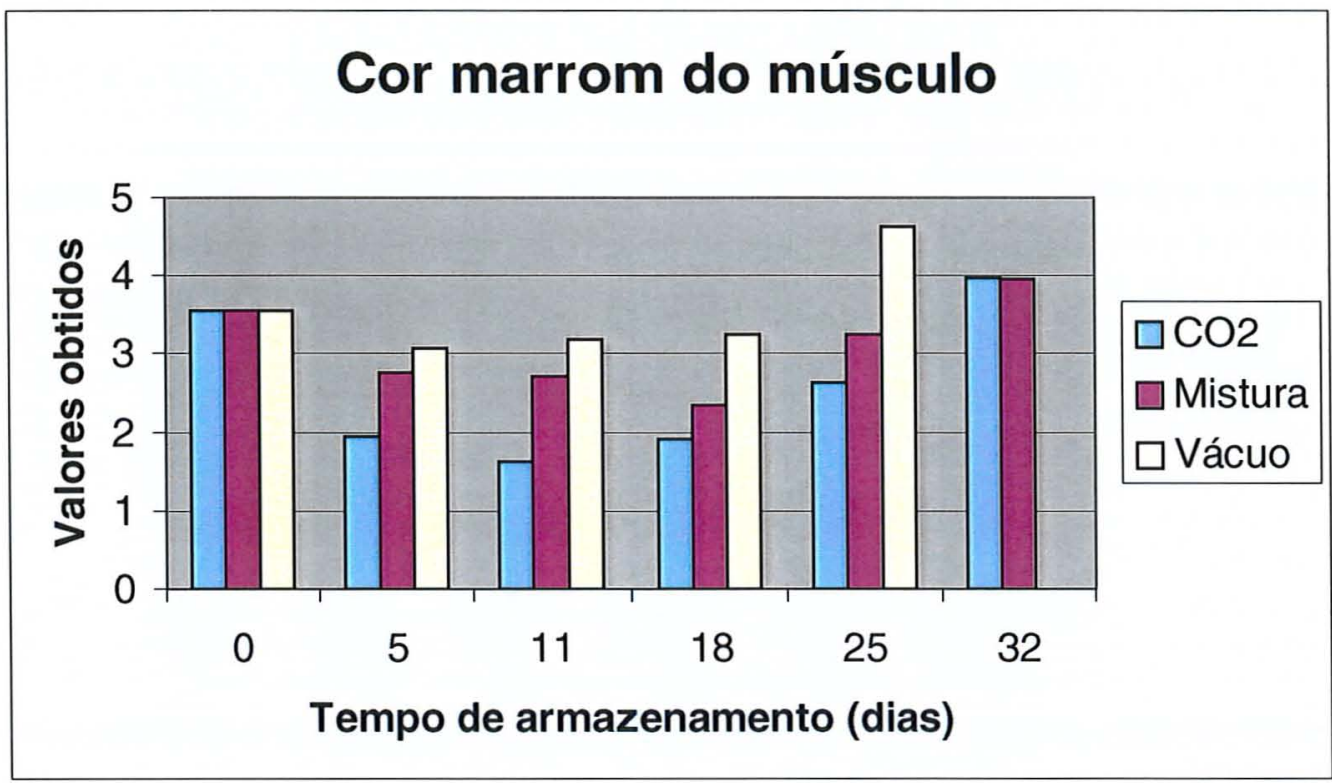

Figura 12 - Evolução das notas do atributo sensorial de aparência "Cor marrom" da bisteca suína embalada em $100 \% \mathrm{CO}_{2}$, mistura e vácuo, durante estocagem a $0+3^{\circ} \mathrm{C}$ nos dias zero, $5,11,18,25$ e 32 de armazenamento

Observando-se a Figura 12, com exceção do tempo zero de armazenamento, houve uma tendência das amostras do tratamento vácuo apresentarem-se com notas de cor marrom maiores (tonalidade de marrom mais intenso) que os outros dois tratamentos estudados $\left(100 \% \mathrm{CO}_{2}\right.$ e mistura), até o $25^{\circ}$ dia de armazenamento, quando a amostra foi rejeitada pela equipe sensorial.

Com relação aos tratamentos com gases $\left(100 \% \mathrm{CO}_{2}\right.$ e mistura), o tratamento mistura apresentou tendência a maiores notas de cor marrom do músculo, o que significa que estava mais escuro, até o $32^{\circ}$ dia de armazenamento, quando demonstrou um "equilíbrio" quanto a coloração marrom com o tratamento $100 \% \mathrm{CO}_{2}$, de acordo com a equipe sensorial.

Com relação à avaliação estatística (Tabela 15 em anexo), no tempo zero de armazenamento não houve diferença estatística $(p \leq 0,05)$ entre os 3 tratamentos estudados em relação ao atributo "Cor marrom" do músculo da bisteca suína em atmosfera modificada.

Aos 5 e 11 dias de armazenamento, o tratamento com $100 \% \mathrm{CO}_{2}$ obteve menor valor de intensidade de cor marrom $(1,95 ; p \leq 0,05)$ com relação aos outros 2 
tratamentos estudados (mistura e vácuo) que não diferiram estatisticamente entre si $(p \leq 0,05)$, mostrando que durante este período, a alta concentração do $\mathrm{CO}_{2}$ não permitiu o escurecimento do músculo.

Com 18 e 25 dias de armazenamento, o tratamento vácuo obteve maiores médias de cor marrom ( 3,26 e 4,63, respectivamente) e foi diferente estatisticamente $(p \leq 0,05)$ dos tratamentos com gás, que não diferiram estatisticamente entre si $(p \leq 0,05)$, demonstrando que a ausência de gases no tratamento vácuo contribuiu significativamente para o escurecimento do músculo da bisteca suína.

Com 32 dias de armazenamento, os tratamentos com gás $\left(100 \% \mathrm{CO}_{2}\right.$ e mistura) não diferiram estatisticamente entre si $(p \leq 0,05)$, o que demonstra que a utilização de gases contribuiu para a manutenção de uma coloração mais próxima da carne suína in natura por mais tempo.

Segundo O'Sullivan et al. (2003), Zanadi et al. (1998) usaram uma equipe com 10 julgadores treinados para julgar a aparência da coloração marrom da metamioglobina e avaliar a evolução da estabilidade da cor três vezes por semana nas bistecas suínas e observaram que as análises estatísticas não mostraram diferença significativa na quantidade de cor marrom nas bistecas.

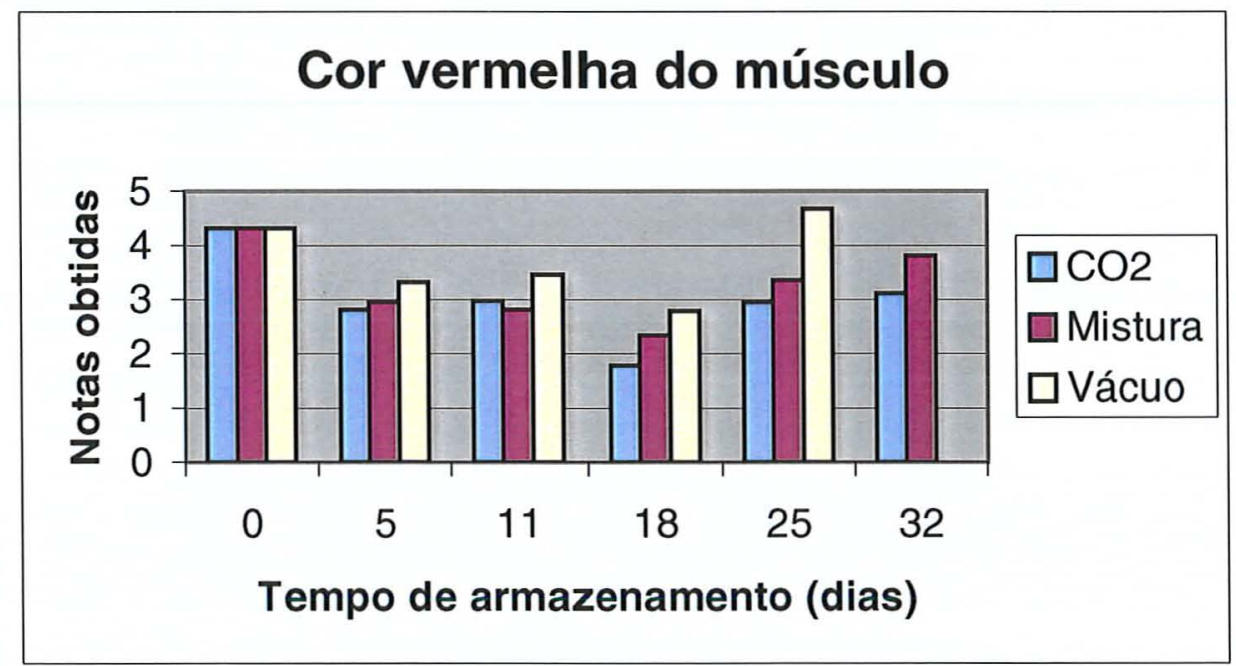

Figura 13 - Evolução das notas do atributo sensorial de aparência "Cor vermelha do músculo" da bisteca suína embalada em $100 \% \mathrm{CO}_{2}$, mistura e vácuo, durante estocagem a $0+3^{\circ} \mathrm{C}$ nos dias zero, $5,11,18,25$ e 32 de armazenamento 
Observando-se a Figura 13, com exceção do tempo zero de armazenamento, houve uma tendência das amostras do tratamento vácuo apresentarem-se com notas de cor vermelha maiores que os outros dois tratamentos estudados ( $100 \% \mathrm{CO}_{2}$ e mistura), até o $25^{\circ}$ dia de armazenamento, quando a amostra estava com uma coloração vermelho-escura intensa e foi rejeitada pela equipe sensorial.

Comparando os 2 tratamentos com gases estudados, até os 11 dias de armazenamento observou-se ligeira diferença nas notas de cor vermelha do músculo entre os tratamentos, de acordo com a equipe sensorial. A partir do $18^{\circ}$ dia de armazenamento, o tratamento mistura apresentou maiores notas médias do atributo "cor vermelha do músculo" (vermelho mais escuro), mantendo essa tendência até o final do experimento (32 dias).

$\mathrm{Na}$ avaliação estatística (Tabela $16 \mathrm{em}$ anexo), nos tempos zero e 5 dias de armazenamento, não houve diferença significativa $(p \leq 0,05)$ entre os três tratamentos estudados com relação ao atributo sensorial "Cor vermelha do músculo".

Com 11 dias de armazenamento, o tratamento mistura apresentou menor média de cor vermelha do músculo $(2,82)$, mas não diferiu estatisticamente $(p \leq 0,05)$ do tratamento com $100 \% \mathrm{CO}_{2}$ e este último não diferiu estatisticamente do tratamento vácuo $(p \leq 0,05)$. Apesar disso, o tratamento vácuo apresentou uma tendência a maior média de cor vermelha do músculo, o que significa que estava mais escuro que as bistecas dos tratamentos com gás e que estes tenderam a ser mais eficientes neste periodo de armazenamento.

Aos 18 dias de armazenamento, o tratamento com $100 \% \mathrm{CO}_{2}$ apresentou a menor média de cor vermelha $(1,8)$, indicando uma coloração vermelha mais viva que as demais, mas não diferiu estatisticamente $(p \leq 0,05)$ do tratamento mistura e este último não diferiu estatisticamente do tratamento vácuo $(p \leq 0,05)$.

Com 25 dias de armazenamento, o tratamento vácuo apresentou a maior média de cor vermelha do músculo $(4,7$; vermelho mais escuro) e diferiu estatisticamente dos tratamentos com gás $(p \leq 0,05)$, demonstrando a importância do $\mathrm{CO}_{2}$ na estabilidade dos pigmentos da carne. A alta contagem microbiana neste período ( 7 log UFC) influenciou efetivamente na alteração da cor da carne, pelos metabólitos produzidos pelas bactérias presentes, assim como as mudanças químicas sofridas pela carne, que resultam em mudanças de coloração (escurecimento), 
conforme explica Molin (2000).

Aos 32 dias de armazenamento, o tratamento com $100 \% \mathrm{CO}_{2}$ obteve a menor média de cor vermelha do músculo $(3,11)$ e diferiu estatisticamente $(p \leq 0,05)$ do tratamento mistura, o que pode ser decorrente das menores contagens microbiológicas neste período de armazenamento neste tratamento em questão, apresentando coloração mais próxima da carne suína in natura.

De acordo com Gill \& Jones (1994), os bifes provenientes do acondicionamento com atmosfera estavam, apenas, levemente desejáveis em relação à melhor aparência, quando subseqüentemente expostos por 4 dias e a metamioglobina constituía a maior porção de pigmento da carne. Entretanto, depois de 6 dias de embalagem em acondicionamento com atmosfera de 100\% dióxido de carbono, uma cor vermelha brilhante se desenvolveu quando a carne foi exposta ao ar.

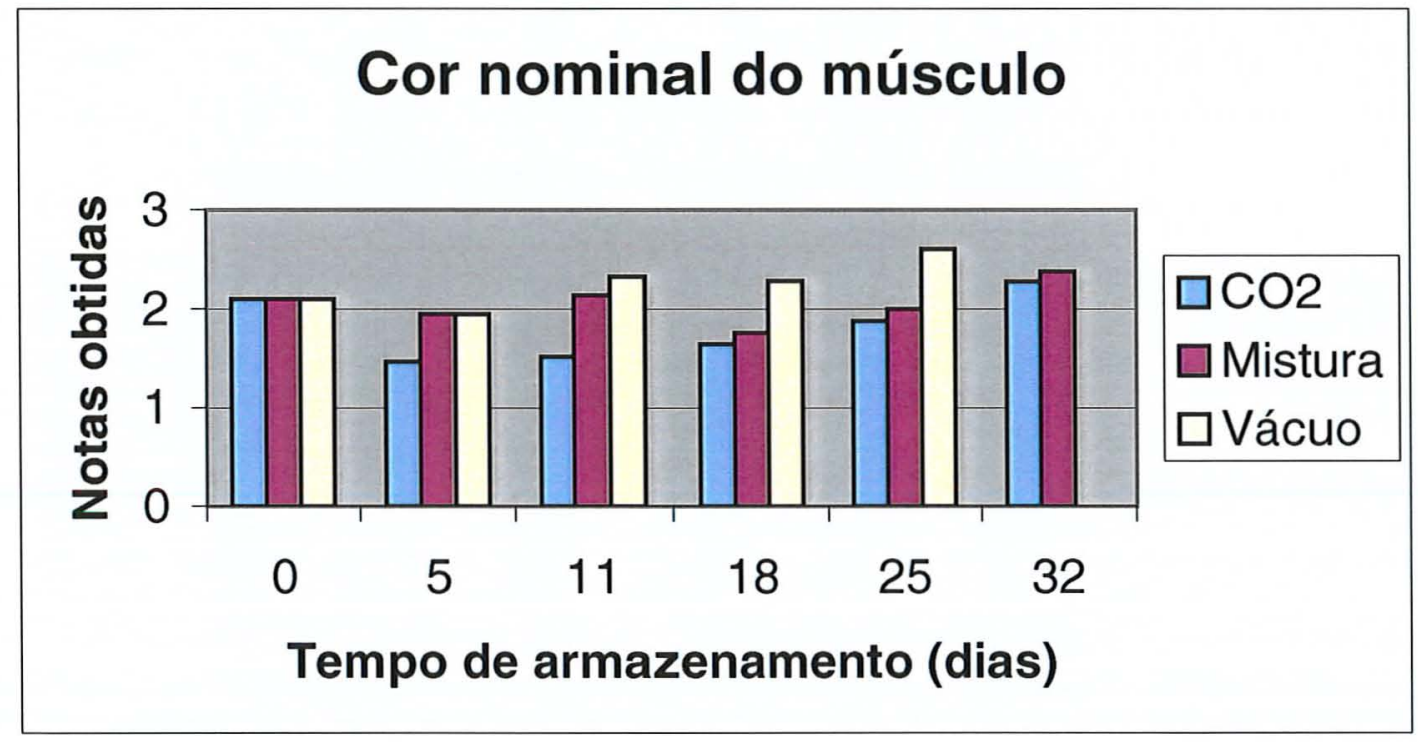

Figura 14 - Evolução das notas do atributo sensorial de aparência "Cor nominal do músculo" da bisteca suína embalada em $100 \% \mathrm{CO}_{2}$, mistura e vácuo, durante estocagem a $0+3^{\circ} \mathrm{C}$ nos dias zero, 5, 11, 18, 25 e 32 de armazenamento

Observando-se a Figura 14, o tratamento vácuo apresentou notas semelhantes ao tratamento mistura até o $5^{\circ}$ dia de armazenamento. A partir do $11^{\circ}$ dia de armazenamento, o vácuo apresentou notas de cor nominal do músculo maiores que os tratamentos com gases, sendo de coloração mais escura e mais distante da 
coloração da bisteca suína in natura, que tende ao rosa claro. Com relação aos 2 tratamentos com gases, no $11^{\circ}$ dia de armazenamento, o tratamento mistura se apresentou mais escuro que o tratamento com $100 \% \mathrm{CO}_{2}$. Nos demais dias, o tratamento mistura apresentou nota de coloração nominal do músculo semelhante ao tratamento com $100 \% \mathrm{CO}_{2}$, demonstrando que a diferença da concentração do $\mathrm{CO}_{2}$ (100 ou 50\%), pouco influenciou neste atributo avaliado, de acordo com a equipe sensorial.

Já na avaliação estatística, como pode ser observado na Tabela $17 \mathrm{em}$ anexo, no tempo zero de armazenamento as amostras não apresentaram diferença estatística $(p \leq 0,05)$ quanto ao atributo avaliado "Cor nominal do músculo" e todas as amostras apresentavam coloração própria de carne suína in natura. Com 5 e 11 dias de armazenamento, o tratamento com $100 \% \mathrm{CO}_{2}$ apresentou as menores médias $(1,5)$ e diferiu estatisticamente $(p \leq 0,05)$ dos outros 2 tratamentos estudados (mistura e vácuo), que não diferiram significativamente $(p \leq 0,05)$ entre si, demonstrando que a alta concentração de $\mathrm{CO}_{2}$ contribuiu para a manutenção da característica da cor do músculo da carne mais próximo das condições de carne fresca in natura, que apresentam uma coloração rósea brilhante (Sorheim et al., 1996).

Com 18 e 25 dias de armazenamento, o tratamento vácuo apresentou as maiores médias de cor nominal do músculo (2,3 e 2,6, respectivamente) e diferiu estatisticamente $(\mathrm{p} \leq 0,05)$ dos outros 2 tratamentos estudados $\left(100 \% \mathrm{CO}_{2}\right.$ e mistura), que não diferiram estatisticamente entre si $(p \leq 0,05)$. Isto pode ser decorrência das maiores contagens microbiológicas do tratamento vácuo nestes periodos de armazenamento estudados, o que pode contribuir para maiores alterações na coloração, como o escurecimento apresentado, assim como encontrado por Sorheim et al. (1996).

Aos 32 dias de armazenamento, os tratamentos com $100 \% \mathrm{CO}_{2}$ e mistura não diferiram estatisticamente entre si $(p \leq 0,05)$, o que pode demonstrar que, neste periodo de armazenamento, as amostras submetidas aos tratamentos com gases atingiram um equilíbrio entre os pigmentos de coloração, apresentando coloração nominal semelhantes.

As bactérias, como as Pseudomonas sp., também causam descoloração da carne quando alcançam níveis $>10^{5} \mathrm{UFC} / \mathrm{g}$ (Renerre, 1990). De acordo com Hood (1980) um aumento de $10^{4}$ para $10^{6} \mathrm{UFC} / \mathrm{g}$ durante 1 semana de estocagem a vácuo a 
$0^{\circ} \mathrm{C}$, causa um decréscimo de $40 \%$ na vida útil da cor da carne. No presente estudo também foi observado uma diminuição na vida útil da bisteca no tratamento vácuo.

O'Keef \& Hood (1982) reportaram que o decréscimo do consumo de oxigênio pelos tecidos musculares com o prolongamento do tempo de estocagem causou rápidas mudanças na cor da carne fresca.

Em condições de aerobiose, os microrganismos podem ocasionar limosidade superficial, como as Pseudomonas $s p$. e a cor vermelha da carne pode adquirir tons de marrom, devido à produção, por bactérias, de $\mathrm{H}_{2} \mathrm{~S}$, compostos oxidantes, como peróxidos, por exemplo (Franco \& Landgraf, 1996).

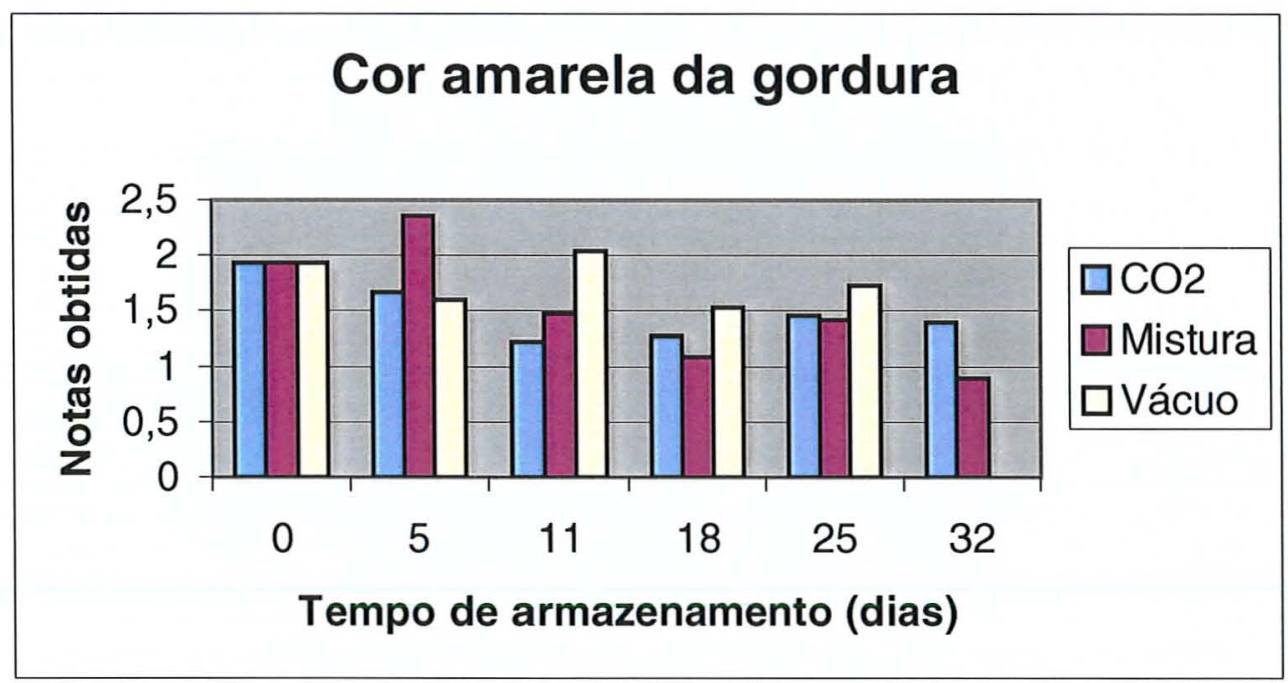

Figura 15 - Evolução das notas do atributo sensorial de aparência "Cor amarela da gordura" da bisteca suína embalada em $100 \% \mathrm{CO}_{2}$, mistura e vácuo, durante estocagem a $0+3^{\circ} \mathrm{C}$ nos dias zero, $5,11,18,25$ e 32 de armazenamento

Como pode ser observado na Figura 15 e na Tabela 18 em anexo, no tempo zero de armazenamento as amostras não apresentaram diferença estatística $(p \leq 0,05)$ quanto ao atributo avaliado "Cor amarela da gordura" e todas as amostras apresentavam a gordura com coloração própria de carne suína in natura.

Aos 5 dias de armazenamento, o tratamento mistura demonstrou maior média de cor amarela de gordura $(2,36)$ e foi diferente estatisticamente $(p \leq 0,05)$ dos 
outros 2 tratamentos estudados $\left(100 \% \mathrm{CO}_{2}\right.$ e vácuo), que não diferiram significativamente entre si $(p \leq 0,05)$.

Com 11 dias de armazenamento, o tratamento vácuo apresentou a maior média de cor amarela da gordura $(2,04)$ e diferiu estatisticamente $(p \leq 0,05)$ dos outros 2 tratamentos estudados $\left(100 \% \mathrm{CO}_{2}\right.$ e mistura), que não diferiram estatisticamente entre si $(p \leq 0,05)$.

Com 18 e 25 dias de armazenamento, os 3 tratamentos estudados não apresentaram diferença estatística $(p \leq 0,05)$ com relação ao atributo sensorial "Cor amarela da gordura", mostrando que, durante este período de armazenamento, os tratamentos estudados não influenciaram nesse parâmetro.

Com 32 dias de armazenamento, o tratamento mistura apresentou menor média de "Cor amarela da gordura" $(0,5)$ e diferiu estatisticamente $(p \leq 0,05)$ do tratamento com $100 \% \mathrm{CO}_{2}$, mostrando que a coloração da gordura das bistecas suínas armazenadas sob o tratamento mistura estava mais próxima da coloração da carne suína in natura, de acordo com a equipe sensorial participante do estudo.

\section{Cor do osso}

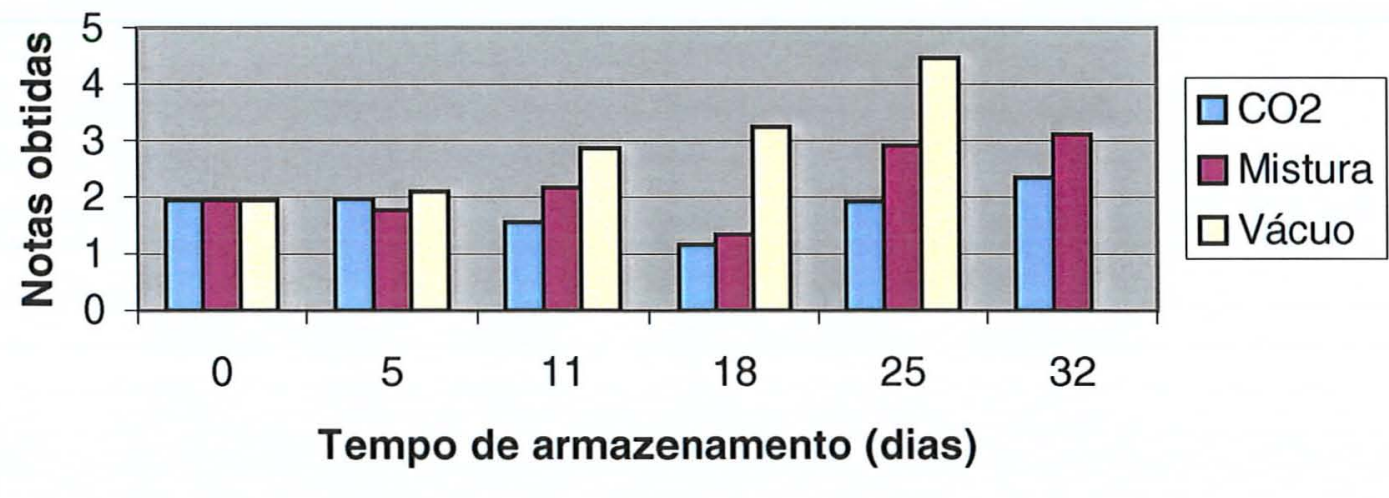

Figura 16 - Evolução das notas do atributo sensorial de aparência "Cor do osso" da bisteca suína embalada em $100 \% \mathrm{CO}_{2}$, mistura e vácuo, durante estocagem a $0+3^{\circ} \mathrm{C}$ nos dias zero, $5,11,18,25$ e 32 de armazenamento 
Observando-se a Figura 16, a coloração do osso das bistecas suínas armazenadas a vácuo, a partir do $5^{\circ}$ dia de armazenamento já demonstrou ter notas mais altas (coloração mais escura, diferente da coloração original do osso recém cortado), sendo considerados mais escuros que os dos tratamentos com gases, e foi julgado inaceitável pela equipe sensorial com 25 dias de armazenamento. Comparando os 2 tratamentos com gases, com exceção do $5^{\circ}$ dia de armazenamento, o tratamento mistura demonstrou coloração mais escura do osso que o tratamento com $100 \% \mathrm{CO}_{2}$, visto que recebeu notas maiores para esse atributo no decorrer do estudo da vida útil.

Como pode ser observado na Tabela $19 \mathrm{em}$ anexo, no tempo zero de armazenamento as amostras não apresentaram diferença estatística $(p \leq 0,05)$ quanto ao atributo avaliado "Cor do osso" e todas as amostras apresentavam o osso com coloração própria de carne suína in natura.

Com 11 dias de armazenamento, o tratamento com $100 \% \mathrm{CO}_{2}$ apresentou a menor média $(1,56)$ e diferiu estatisticamente $(p \leq 0,05)$ dos outros 2 tratamentos estudados (mistura e vácuo) que também diferiram estatisticamente entre si $(p \leq 0,05)$. Assim, observa-se que as bistecas suinas do tratamento com $100 \% \mathrm{CO}_{2}$ apresentaram o osso mais claro que as dos outros 2 tratamentos, mantendo-se mais próxima das características do osso presente na carne in natura, que deve apresentar-se de coloração clara (O’Keef \& Hood, 1982).

Aos 18 dias de armazenamento, o tratamento vácuo apresentou coloração do osso mais escura $(p \leq 0,05)$ que os outros 2 tratamentos estudados $\left(100 \% \mathrm{CO}_{2}\right.$ e mistura) que não apresentaram diferença estatística $(p \leq 0,05)$ entre si.

Com 25 dias de armazenamento, o tratamento vácuo apresentou coloração do osso mais escura $(4,47 ; p \leq 0,05)$ que os demais tratamentos, que também diferiram significativamente $(p \leq 0,05)$ entre $s i$, sendo o tratamento com $100 \% \mathrm{CO}_{2}$ o que apresentou coloração mais clara do osso. Isso mostra que o aumento da concentração de $\mathrm{CO}_{2}$ e baixa concentração de $\mathrm{O}_{2}$ são importantes na manutenção da coloração clara do osso da bisteca suína, mais próxima da coloração do osso presente na carne suína in natura.

Com 32 dias de armazenamento, o tratamento com $100 \% \mathrm{CO}_{2}$ foi estatisticamente mais eficiente $(p \leq 0,05)$ na manutenção da cor clara do osso, apesar das altas contagens microbiológicas presentes na bisteca nesse período de armazenamento. 


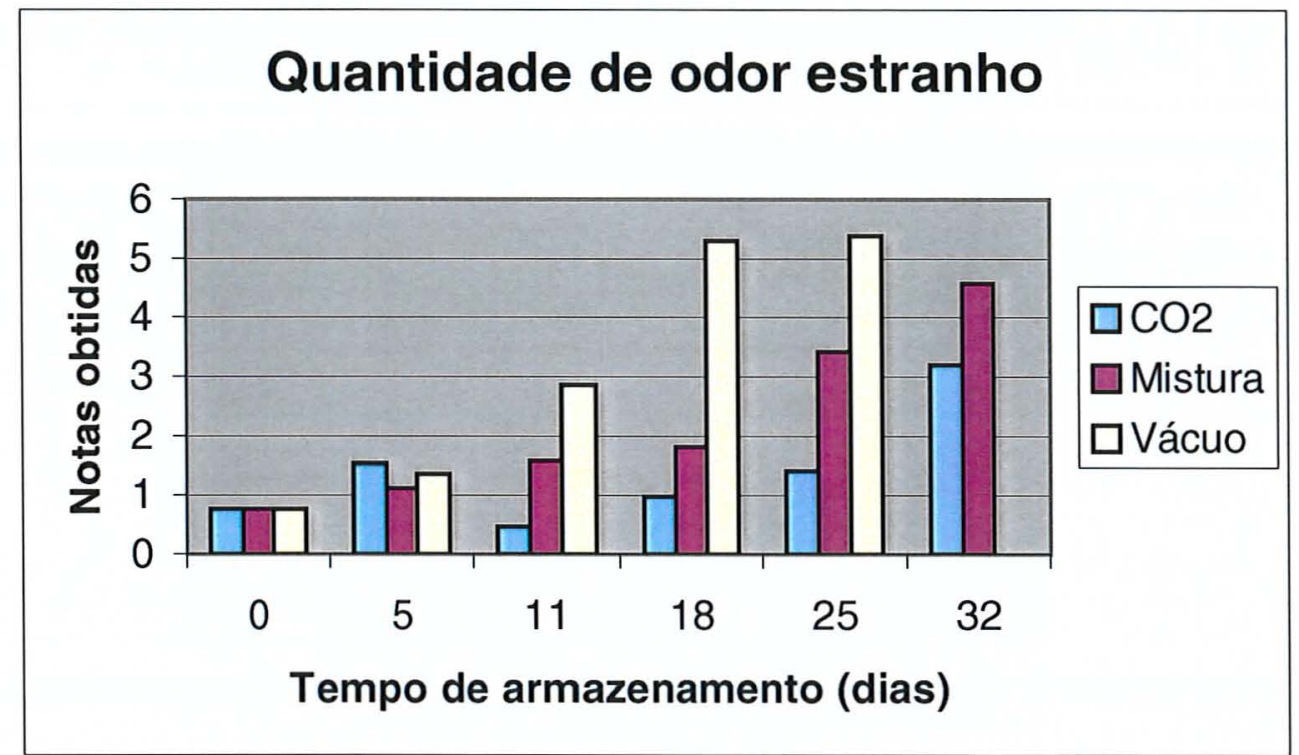

Figura 17 - Evolução das notas do atributo sensorial de odor "quantidade de odor estranho" da bisteca suína embalada em $100 \% \mathrm{CO}_{2}$, mistura e vácuo, durante estocagem a $0+3^{\circ} \mathrm{C}$ nos dias zero, $5,11,18,25$ e 32 de armazenamento

Observando-se a Figura 17, com relação à quantidade de odor estranho percebido, o tratamento vácuo demonstrou uma tendência a maiores notas (odores estranhos aos da carne suína in natura) obtidas desde o $11^{\circ}$ dia de armazenamento, com crescimento progressivo até o $25^{\circ}$ dia de armazenamento, quando foi rejeitada pela equipe sensorial. Comparando-se os 2 tratamentos com gases, o tratamento com $100 \% \mathrm{CO}_{2}$ foi o que apresentou menores notas obtidas, demonstrando que durante a vida útil, foi o tratamento que mais prolongou o odor mais próximo ao da carne fresca, aumentando a quantidade de odor estranho percebido de acordo com a equipe sensorial ao final do experimento (32 dias de armazenamento).

Como pode ser observado na Tabela $20 \mathrm{em}$ anexo, no tempo zero de armazenamento as amostras não apresentaram diferença estatística $(p \leq 0,05)$ quanto ao atributo avaliado "Odor estranho" e todas as amostras apresentavam o odor característico de carne suína in natura.

Com 11 dias de armazenamento, o tratamento vácuo apresentou a maior média de quantidade de odor estranho $(2,86)$ e diferiu estatisticamente $(p \leq 0,05)$, dos 
outros 2 tratamentos estudados $\left(100 \% \mathrm{CO}_{2}\right.$ e mistura), que também diferiram estatisticamente entre $\mathrm{si}(\mathrm{p} \leq 0,05)$.

Essa diferença na quantidade de odor estranho percebido se tornou mais evidente a partir dos 18 dias de armazenamento, onde a média do odor percebido no tratamento vácuo ultrapassa $50 \%$ da escala, sendo estatisticamente diferente $(p \leq 0,05)$ dos outros 2 tratamentos estudados $\left(100 \% \mathrm{CO}_{2}\right.$ e mistura), que não diferiram estatisticamente entre si $(p \leq 0,05)$. Esse resultado foi decorrente das maiores contagens microbiológicas no tratamento vácuo nesse período de análise, onde 0 metabolismo pode contribuir na formação de odores estranhos, assim como foi citado por Garcia-Lopez et al. (1998).

Aos 32 dias de armazenamento, o tratamento mistura apresentou média de odor estranho maior que o tratamento com $100 \% \mathrm{CO}_{2}(p \leq 0,05)$, o que pode ter sido decorrente da maior contagem microbiológica ( $>7 \log$ UFC) no tratamento mistura, com metabolismo resultando na formação de odores estranhos indicando alto grau de deterioração, como explica Bomar (1985).

As mudanças microbiológicas de carne refrigerada de $\mathrm{pH}$ normal $(\sim 5,5)$ armazenadas em atmosfera modificada são razoavelmente bem estabilizadas. A microbiota final é composta, em ordem decrescente de magnitude, por bactérias lácticas, Enterobacteriaceae e Pseudomonas (Asensio et al., 1988). No entanto, o pH pode representar um importante papel no tipo de microbiota predominante e, por isso, na formação de odores estranhos.

Os odores e sabores estranhos geralmente são perceptiveis nas carnes antes que qualquer outro sinal de deterioração o seja. Os ácidos voláteis como 0 fórmico, acético, butírico e propiônico são responsáveis pelo odor ácido. A expressão "aroma de geladeira" é usada para designar, de maneira indefinida, um aroma adulterado (Franco \& Landgraf, 1996). 


\section{Tipo de odor percebido}

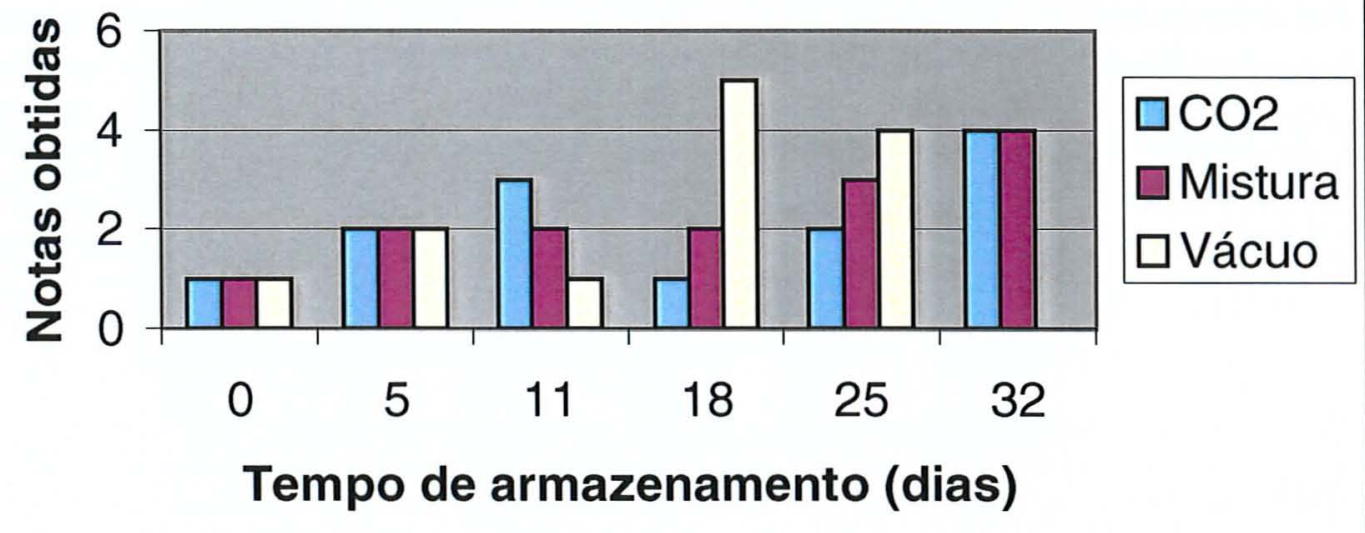

Figura 18 - Evolução das notas do atributo sensorial de odor "Tipo de odor percebido" da bisteca suína embalada em $100 \% \mathrm{CO}_{2}$, mistura e vácuo, durante estocagem a $0+3^{\circ} \mathrm{C}$ nos dias zero, $5,11,18,25$ e 32 de armazenamento

Observando-se a Figura 18 e a Tabela 21 em anexo, no tempo zero de armazenamento a bisteca suína apresentou nota $=1$, o que correspondia a odor de carne fresca. Com 5 dias de armazenamento, os 3 tratamentos estudados apresentaram nota $=2$ para o tipo de odor, o que correspondia a odor de carne guardada e/ou geladeira. Nos tempos zero e 5 dias de armazenamento, os 3 tratamentos estudados não apresentaram diferença estatística $(p \leq 0,05)$ quanto ao atributo sensorial "Tipo de odor percebido".

Aos 11 dias de armazenamento, todos os tratamentos foram estatisticamente diferentes entre si $(p \leq 0,05)$, sendo que o tratamento vácuo, neste período apresentou nota média $=1$, o que correspondia a odor de carne fresca pela maioria da equipe sensorial, o tratamento mistura apresentou nota média $=2$, que correspondia a odor de carne guardada e/ou geladeira e, o tratamento $\mathrm{com} 100 \% \mathrm{CO}_{2}$ apresentou nota média= 3 , que correspondia a odor de fruta/ doce, o que pode ter sido decorrente de algum problema com as amostras avaliadas neste dia, visto que após esse período, o odor das bistecas deste tratamento voltaram a apresentar notas médias $=2$ (carne guardada e/ou geladeira), até o final do experimento, aos 32 dias de armazenamento, quando apresentaram nota média $=4$, que correspondia a odor fermentado, que pode ser decorrente da alta contagem microbiológica neste período (principalmente bactérias 
lácticas, que apresentaram contagens próximas a 8 log de UFC neste período, e têm produtos finais de seu metabolismo que apresentem odor semelhante a "pão fermentado", como explica Garcia-Lopez et al. (1998)), indicando avançado grau de deterioração.

Com 18 dias de armazenamento, os tratamentos com gases $\left(100 \% \mathrm{CO}_{2} \mathrm{e}\right.$ mistura), não apresentaram diferença significativa entre si $(p \leq 0,05)$ e apresentaram nota média $=2$, que correspondia a odor de carne guardada e/ou geladeira e foram estatisticamente diferentes $(p \leq 0,05)$ do tratamento vácuo, que apresentou nota média = 5 , o que correspondia a odor de azedo, mostrando já elevado grau de deterioração. Este último tratamento manteve esta nota quanto ao atributo sensorial "Tipo de odor percebido" aos 25 dias de armazenamento, quando foi finalmente rejeitado pela equipe sensorial.

Com relação aos tratamentos com gases $\left(100 \% \mathrm{CO}_{2}\right.$ e mistura), no $25^{\circ}$ dia de armazenamento o tratamento com $100 \% \mathrm{CO}_{2}$ apresentou menor nota média (2, que correspondia a odor de carne guardada e/ou geladeira) e o tratamento mistura apresentou nota média $=3$, que correspondia a odor de fruta/ doce pela equipe sensorial, que pode ocorrer devido ao metabolismo de carboidratos pelas Pseudomonas $\mathrm{sp}$. Com liberação de cetonas e álcoois que exibem uma variedade de odores doces e de frutas, como explica Garcia-Lopez et al. (1998).

No final da vida útil das bistecas suínas acondicionadas em atmosfera gasosa (32 dias de armazenamento), ambos os tratamentos $\left(100 \% \mathrm{CO}_{2}\right.$ e mistura) apresentaram nota média $=4$, que correspondia ao odor fermentado e foram rejeitadas pela equipe sensorial. Estatisticamente, os 2 tratamentos não diferiram entre si $(p \leq 0,05)$, o que significa que, ao final do experimento, a concentração de $\mathrm{CO}_{2}$ não mais influenciou neste parâmetro, não impedindo a deterioração. 


\section{Qualidade geral das bistecas suínas}

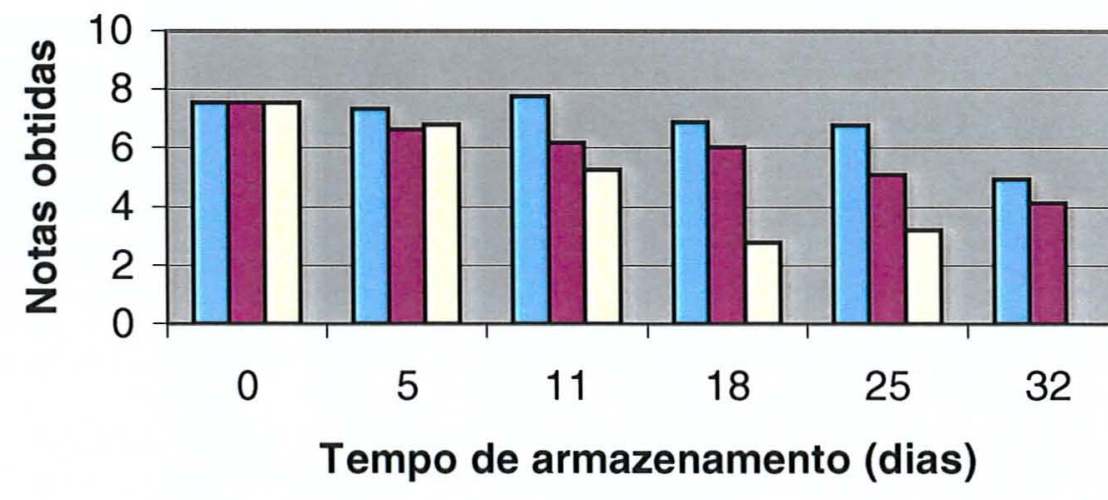

Figura 19 - Evolução das notas do atributo sensorial "Qualidade Geral" da bisteca suína embalada em $100 \% \mathrm{CO}_{2}$, mistura e vácuo, durante estocagem a $0+3^{\circ} \mathrm{C}$ nos dias zero, $5,11,18,25$ e 32 de armazenamento

Como pode ser observado na Figura 19 e na Tabela 22 em anexo, nos tempos zero e 5 dias de armazenamento, os três tratamentos estudados não apresentaram diferença estatística entre si $(p \leq 0,05)$ com relação ao atributo sensorial "Qualidade geral".

Com 11, 18 e 25 dias de armazenamento, a qualidade geral das bistecas suínas do tratamento com $100 \% \mathrm{CO}_{2}$ foram estatisticamente superiores $(p \leq 0,05)$ às bistecas dos tratamentos com mistura e vácuo, que também diferiram estatisticamente $(p \leq 0,05)$ entre $s i$, sendo que o tratamento vácuo sempre apresentava as menores médias, demonstrando que esse tratamento foi classificado pela equipe sensorial como de qualidade inferior às bistecas com tratamentos com gás, sendo rejeitada aos 25 dias de armazenamento.

Com 32 dias de armazenamento, as bistecas suínas dos 2 tratamentos com gás diferiram estatisticamente entre si $(p \leq 0,05)$ e apresentaram médias menores que 5,0 , indicando que ambos os tratamentos já estavam com a qualidade comprometida com este tempo de armazenamento.

Segundo Pierson et al. (1970), se comparada à embalagem aeróbica, as embalagens com ATM de baixo oxigênio, não apresentaram diferenças nos atributos 
sensoriais de carne fresca por até 10 dias, enquanto carne estocada aerobicamente estava inaceitável depois de 4 dias.

Aos 25 dias de armazenamento o tratamento vácuo apresentou-se com características de putrefação, enquanto os 2 tratamentos com gases $\left(100 \% \mathrm{CO}_{2}\right.$ e mistura) atingiram este estágio aos 32 dias de armazenamento. A putrefação, um tipo de biodeterioração protéica, facilmente detectada, resulta da ação de microrganismos sobre aminoácidos, nucleotídeos e outros compostos nitrogenados de baixo peso molecular. Nesta reação ocorre a formação de substâncias de odor pútrido (mercaptanas, aminas, etc). A ruptura da molécula protéica provoca, entre outros defeitos no alimento, alterações na textura, como o amolecimento dos tecidos e alterações no aroma. Quanto mais avançado estiver o processo de deterioração, mais marcantes serão as alterações verificadas nos alimentos. Nesse tipo de biodeterioração verifica-se uma elevação do $\mathrm{pH}$, o que indica a degradação desse tipo de substância (Franco \& Landgraf, 1996). 


\section{CONCLUSÕES}

- A eficiência do tratamento com $\mathrm{CO}_{2}$ pode ser constatada após 11 dias (enterobactérias, $p \leq 0,05$ ) e 18 dias (Bactérias lácticas, $p \leq 0,05$, Pseudomonas $s p ., p \leq 0,05$ e psicrotróficos, $p \leq 0,05$ ) de estocagem refrigerada. $O$ tratamento mistura $\left(50 \% \mathrm{CO}_{2} / 50 \% \mathrm{~N}_{2}\right)$ mostrou também sua eficiência no controle do desenvolvimento dos microrganismos avaliados, embora não tenha mostrado diferença significativa com o controle (vácuo). Verifica-se ainda um aumento nas contagens dos microrganismos em função do período de estocagem, excetuando as Pseudomonas sp. e enterobactérias, que não demonstraram a mesma tendência.

- O uso do $\mathrm{CO}_{2}\left(100 \% \mathrm{CO}_{2}\right.$ e $\left.50 \% \mathrm{CO}_{2} / 50 \% \mathrm{~N}_{2}\right)$ estabilizou a população de Pseudomonas sp., a partir do $11^{\circ}$. e $18^{\circ}$ dia de armazenamento, respectivamente, a $0+3^{\circ} \mathrm{C}$, enquanto que, no controle (vácuo), esta população proliferou continuamente até o final do experimento.

- Os tratamentos estudados não foram eficientes sobre as populações de bactérias lácticas e psicrotróficos presentes nas amostras de bisteca suína, pois estas proliferaram continuamente até $025^{\circ}$ dia de armazenamento no tratamento vácuo e até $032^{\circ}$ dia de armazenamento pras os tratamentos $100 \% \mathrm{CO}_{2}$ e mistura.

- Os tratamentos com gases $\left(100 \% \mathrm{CO}_{2}\right.$ e mistura) estavam com aparência aceitável sensorialmente ao final do experimento (32 dias de armazenamento), apesar de apresentarem alta contagem microbiológica (ao redor de $10^{7}$ UFC) nesse período. 
- O tratamento vácuo foi rejeitado sensorialmente com 25 dias de armazenamento.

- Microbiologicamente, o tempo de vida útil das bistecas suínas sob $100 \% \mathrm{CO}_{2}$ foi entre 18 e 25 dias de armazenamento, quando já atingiu contagens ao redor de $10^{7}$ UFC para a maioria dos microrganismos estudados. Sob o tratamento mistura, o tempo de vida útil também variou entre 18 e 25 dias de armazenamento, devido as mesmas condições apresentadas pelo tratamento com $100 \% \mathrm{CO}_{2}$. A vida útil do tratamento vácuo foi de 11 a 18 dias de armazenamento, quando atingiu contagem microbiológica ao redor de $10^{7}$ UFC da maioria dos microrganismos estudados.

- A utilização dos 3 tratamentos estudados foi eficiente na inibição do desenvolvimento de Listeria monocytogens, presente na matéria-prima.

- A aplicação de atmosfera modificada, juntamente com baixas temperaturas, aumentam a vida útil da bisteca suina, impedindo o desenvolvimento microbiano no produto e mantendo as características sensoriais. 
ANEXOS 
Tabela 4. Contagem microbiológica de bactérias lácticas da bisteca suína embalada em $100 \% \mathrm{CO}_{2}$, mistura $\left(50 \% \mathrm{CO}_{2} / 50 \% \mathrm{~N}_{2}\right)$ e vácuo, durante estocagem a $0 \pm$ $2^{\circ} \mathrm{C}$ no periodo de zero, $5,11,18.25$ e 32 dias de armazenamento

\begin{tabular}{llll}
\hline Bactérias láticas & $\mathrm{CO}_{2}$ & Mistura & Vácuo \\
\hline Dia zero & $4,08^{\mathrm{a}} \pm 0,18$ & $4,08^{\mathrm{a}} \pm 0,18$ & $4,08^{\mathrm{a}} \pm 0,18$ \\
\hline Dia 5 & $2,67^{\mathrm{a}} \pm 0,17$ & $3,06^{\mathrm{a}} \pm 0,50$ & $2,50^{\mathrm{a}} \pm 0,19$ \\
Dia 11 & $4,91^{\mathrm{a}} \pm 0,54$ & $6,21^{\mathrm{a}} \pm 0,46$ & $5,88^{\mathrm{a}} \pm 0,73$ \\
Dia 18 & $6,44^{\mathrm{b}} \pm 0,67$ & $7,45^{\mathrm{a}} \pm 0,37$ & $7,81^{\mathrm{a}} \pm 0,27$ \\
Dia 25 & $6,79^{\mathrm{b}} \pm 0,15$ & $7,73^{\mathrm{a}} \pm 0,07$ & $7,48^{\mathrm{a}} \pm 0,41$ \\
Dia 32 & $7,71^{\mathrm{b}} \pm 0,06$ & $8,06^{\mathrm{a}} \pm 0,13$ & $\mathrm{nr}$ \\
\hline
\end{tabular}

Nota: letras diferentes nas linhas indicam diferenças significativas $(p \leq 0,05)$ entre os tratamentos, no mesmo dia de análise

Média \pm Desvio Padrão

$\mathrm{nr}=$ não realizado

Tabela 5. Contagem microbiológica de Pseudomonas da bisteca suina embalada em $100 \% \mathrm{CO}_{2}$, mistura $\left(50 \% \mathrm{CO}_{2} / 50 \% \mathrm{~N}_{2}\right)$ e vácuo, durante estocagem a $0 \pm 2{ }^{\circ} \mathrm{C}$ no período de zero, $5,11,18.25$ e 32 dias de armazenamento

\begin{tabular}{llll}
\hline Pseudomonas & $\mathrm{CO}_{2}$ & Mistura & Vácuo \\
\hline Dia zero & $5,13^{\mathrm{a}} \pm 0,41$ & $5,13^{\mathrm{a}} \pm 0,41$ & $5,13^{\mathrm{a}} \pm 0,41$ \\
Dia 5 & $3,11^{\mathrm{a}} \pm 0,10$ & $2,93^{\mathrm{a}} \pm 0,81$ & $3,30^{\mathrm{a}} \pm 0,55$ \\
Dia 11 & $4,31^{\mathrm{a}} \pm 0,51$ & $4,62^{\mathrm{a}} \pm 0,76$ & $5,78^{\mathrm{a}} \pm 1,13$ \\
Dia 18 & $4,34^{\mathrm{b}} \pm 0,68$ & $5,83^{\mathrm{a}} \pm 0,31$ & $6,79^{\mathrm{a}} \pm 0,23$ \\
Dia 25 & $3,47^{\mathrm{b}} \pm 1,32$ & $5,90^{\mathrm{a}} \pm 0,06$ & $6,17^{\mathrm{a}} \pm 0,31$ \\
Dia 32 & $4,84^{\mathrm{b}} \pm 0,52$ & $6,74^{\mathrm{a}} \pm 0,47$ & $\mathrm{nr}$ \\
\hline
\end{tabular}

Nota: letras diferentes nas linhas indicam diferenças significativas $(p \leq 0,05)$ entre os tratamentos, no mesmo dia de análise

Média \pm Desvio Padrão

$\mathrm{nr}=$ não realizado 
Tabela 6. Contagem microbiológica de enterobactérias da bisteca suína embalada em $100 \% \mathrm{CO}_{2}$, mistura $\left(50 \% \mathrm{CO}_{2} / 50 \% \mathrm{~N}_{2}\right)$ e vácuo, durante estocagem a $0+3^{\circ} \mathrm{C}$ no período de zero, $5,11,18.25$ e 32 dias de armazenamento

\begin{tabular}{llll}
\hline Enterobactérias & $\mathrm{CO}_{2}$ & Mistura & Vácuo \\
\hline Dia zero & $3,62^{\mathrm{a}} \pm 0,24$ & $3,62^{\mathrm{a}} \pm 0,24$ & $3,62^{\mathrm{a}} \pm 0,24$ \\
\hline Dia 5 & $1,23^{\mathrm{a}} \pm 0,40$ & $1,92^{\mathrm{a}} \pm 0,67$ & $1,46^{\mathrm{a}} \pm 0,15$ \\
Dia 11 & $2,75^{\mathrm{b}} \pm 0,24$ & $3,34^{\mathrm{a}} \pm 0,58$ & $4,40^{\mathrm{a}} \pm 0,84$ \\
Dia 18 & $1,58^{\mathrm{b}} \pm 0,51$ & $1,84^{\mathrm{b}} \pm 1,45$ & $5,80^{\mathrm{a}} \pm 0,18$ \\
Dia 25 & $1,88^{\mathrm{c}} \pm 0,20$ & $4,07^{\mathrm{b}} \pm 0,54$ & $5,20^{\mathrm{a}} \pm 0,41$ \\
Dia 32 & $3,76^{\mathrm{a}} \pm 1,24$ & $5,51^{\mathrm{a}} \pm 0,36$ & $\mathrm{nr}$ \\
\hline
\end{tabular}

Nota: letras diferentes nas linhas indicam diferenças significativas $(p \leq 0,05)$ entre os tratamentos, no mesmo dia de análise

Média \pm Desvio Padrão

$\mathrm{nr}=$ não realizado

Tabela 7. Contagem microbiológica de psicrotróficos da bisteca suína embalada em $100 \% \mathrm{CO}_{2}$, mistura $\left(50 \% \mathrm{CO}_{2} / 50 \% \mathrm{~N}_{2}\right)$ e vácuo, durante estocagem a $0 \pm 2^{\circ} \mathrm{C}$ no periodo de zero, $5,11,18.25$ e 32 dias de armazenamento

\begin{tabular}{llll}
\hline Psicrotróficos & $\mathrm{CO}_{2}$ & Mistura & Vácuo \\
\hline Dia zero & $5,10^{\mathrm{a}} \pm 0,32$ & $5,10^{\mathrm{a}} \pm 0,32$ & $5,10^{\mathrm{a}} \pm 0,32$ \\
Dia 5 & $2,85^{\mathrm{a}} \pm 0,62$ & $3,47^{\mathrm{a}} \pm 0,56$ & $2,80^{\mathrm{a}} \pm 0,19$ \\
Dia 11 & $5,11^{\mathrm{a}} \pm 0,43$ & $6,62^{\mathrm{a}} \pm 0,88$ & $5,46^{\mathrm{a}} \pm 1,32$ \\
Dia 18 & $6,65^{\mathrm{b}} \pm 0,57$ & $7,44^{\mathrm{ab}} \pm 0,39$ & $7,96^{\mathrm{a}} \pm 0,21$ \\
Dia 25 & $6,72^{\mathrm{b}} \pm 0,26$ & $7,79^{\mathrm{a}} \pm 0,04$ & $7,52^{\mathrm{a}} \pm 0,12$ \\
Dia 32 & $7,86^{\mathrm{b}} \pm 0,12$ & $8,39^{\mathrm{a}} \pm 0,11$ & $\mathrm{nr}$ \\
\hline
\end{tabular}

Nota: letras diferentes nas linhas indicam diferenças significativas $(p \leq 0,05)$ entre os tratamentos, no mesmo dia de análise

Média \pm Desvio Padrão

$\mathrm{nr}=$ não realizado 
Tabela 8. Valores da concentração de $\mathrm{CO}_{2}, \mathrm{~N}_{2}$ e $\mathrm{O}_{2}$ das embalagens secundárias das bistecas suínas em $100 \% \mathrm{CO}_{2}$ durante a estocagem a $0+3^{\circ} \mathrm{C}$ nos dias zero, $5,11,18,25$ e 32 de armazenamento

\begin{tabular}{llll}
\hline & & \multicolumn{3}{c}{$100 \% \mathrm{CO}_{2}$} \\
\hline Dia & $\mathrm{CO}_{2}$ & $\mathrm{~N}_{2}$ & $\mathrm{O}_{2}$ \\
\hline 0 & & & \\
\hline 5 & $99,9^{\mathrm{a}}$ & $0,10^{\mathrm{a}}$ & $0,0005^{\mathrm{a}}$ \\
11 & $99,7^{\mathrm{a}}$ & $1,54^{\mathrm{a}}$ & $0,2550^{\mathrm{a}}$ \\
18 & $98,45^{\mathrm{a}}$ & $0,29^{\mathrm{a}}$ & $0,0100^{\mathrm{a}}$ \\
25 & $98,2^{\mathrm{a}}$ & $7,10^{\mathrm{a}}$ & $0,5465^{\mathrm{a}}$ \\
32 & $97,5^{\mathrm{a}}$ & $1,54^{\mathrm{a}}$ & $0,0080^{\mathrm{a}}$ \\
\hline
\end{tabular}

Nota: letras minúsculas diferentes nas colunas indicam se houve diferença significativa $(p \leq 0,05)$ entre os dias de análise $(p \leq 0,05)$ para cada gás estudado

Tabela 9. Valores da concentração de $\mathrm{CO}_{2}, \mathrm{~N}_{2}$ e $\mathrm{O}_{2}$ das embalagens secundárias das bistecas suínas em mistura durante a estocagem a $0+3^{\circ} \mathrm{C}$ nos dias zero, 5 , $11,18,25$ e 32 de armazenamento

\begin{tabular}{llll}
\hline & & \multicolumn{2}{c}{ Mistura } \\
\hline Dia & $\mathrm{CO}_{2}$ & $\mathrm{~N}_{2}$ & $\mathrm{O}_{2}$ \\
0 & $50,15^{\mathrm{a}}$ & $49,85^{\mathrm{b}}$ & $0,000^{\mathrm{a}}$ \\
5 & $44,3^{\mathrm{ab}}$ & $55,30^{\mathrm{ab}}$ & $0,45^{\mathrm{a}}$ \\
11 & $38,80^{\mathrm{b}}$ & $61,20^{\mathrm{a}}$ & $0,83^{\mathrm{a}}$ \\
18 & $40,55^{\mathrm{b}}$ & $59,45^{\mathrm{a}}$ & $0,000^{\mathrm{a}}$ \\
25 & $44,35^{\mathrm{ab}}$ & $55,64^{\mathrm{ab}}$ & $0,0005^{\mathrm{a}}$ \\
32 & $42,65^{\mathrm{b}}$ & $57,35^{\mathrm{ab}}$ & $0,0000^{\mathrm{a}}$ \\
\hline
\end{tabular}

Nota: letras minúsculas diferentes nas colunas indicam se houve diferença significativa $(p \leq 0,05)$ entre os dias de análise $(p \leq 0,05)$ para cada gás estudado 
Tabela 10. Valores instrumentais da cor $L^{*}$ da bisteca suína embalada em $100 \% \mathrm{CO}_{2}$, Mistura $\left(50 \% \mathrm{CO}_{2} / 50 \% \mathrm{~N}_{2}\right)$ e vácuo, durante estocagem a $0+3^{\circ} \mathrm{C}$ nos dias zero, $5,11,18,25$ e 32 de armazenamento

\begin{tabular}{llll}
\hline & & \multicolumn{2}{c}{$L^{*}$} \\
\hline & $100 \%$ CO2 & Mistura & Vácuo \\
\hline 0 & $47,9^{\mathrm{a}} \pm 3,5$ & $47,9^{\mathrm{a}} \pm 3,5$ & $47,9^{\mathrm{a}} \pm 3,5$ \\
5 & $49,6^{\mathrm{a}} \pm 2,6$ & $49,3^{\mathrm{a}} \pm 2,9$ & $48,1^{\mathrm{a}} \pm 2,4$ \\
11 & $51,7^{\mathrm{a}} \pm 1,6$ & $49,9^{\mathrm{a}} \pm 2,1$ & $48,5^{\mathrm{a}} \pm 3,9$ \\
18 & $51,2^{\mathrm{a}} \pm 0,3$ & $51,1^{\mathrm{a}} \pm 2,5$ & $47,5^{\mathrm{a}} \pm 1,6$ \\
25 & $51,6^{\mathrm{a}} \pm 1,7$ & $53,2^{\mathrm{a}} \pm 2,2$ & $49,9^{\mathrm{a}} \pm 3,1$ \\
32 & $53,8^{\mathrm{a}} \pm 1,1$ & $52,5^{\mathrm{a}} \pm 2,0$ & nr \\
\hline
\end{tabular}

Nota: letras maiúsculas diferentes indicam se houve diferença significativa $(p \leq 0,05)$ entre os tratamentos em cada dia de análise $(p \leq 0,05)$

Média \pm Desvio Padrão

$\mathrm{nr}=$ não realizado

Tabela 11. Valores instrumentais da cor $a^{*}$ da bisteca suína embalada em $100 \% \mathrm{CO}_{2}$, Mistura $\left(50 \% \mathrm{CO}_{2} / 50 \% \mathrm{~N}_{2}\right)$ e vácuo, durante estocagem a $0+3^{\circ} \mathrm{C}$ nos dias zero, $5,11,18,25$ e 32 de armazenamento

\begin{tabular}{llll}
\hline & & \multicolumn{3}{l}{$\mathrm{a}^{\mathrm{a}}$} & \\
\hline & $100 \%$ CO2 & Mistura & Vácuo \\
0 & $2,3^{\mathrm{a}} \pm 0,8$ & $2,3^{\mathrm{a}} \pm 0,8$ & $2,3^{\mathrm{a}} \pm 0,8$ \\
5 & $2,8^{\mathrm{a}} \pm 0,8$ & $1,1^{\mathrm{a}} \pm 0,9$ & $1,5^{\mathrm{a}} \pm 0,8$ \\
11 & $1,8^{\mathrm{a}} \pm 1,1$ & $1,8^{\mathrm{a}} \pm 0,3$ & $1,7^{\mathrm{a}} \pm 0,7$ \\
18 & $1,7^{\mathrm{a}} \pm 0,8$ & $1,6^{\mathrm{a}} \pm 1,5$ & $0,7^{\mathrm{a}} \pm 0,4$ \\
25 & $2,7^{\mathrm{a}} \pm 0,6$ & $1,4^{\mathrm{a}} \pm 0,7$ & $2,8^{\mathrm{a}} \pm 1,3$ \\
32 & $3,1^{\mathrm{a}} \pm 1,2$ & $3,7^{\mathrm{a}} \pm 0,3$ & $\mathrm{nr}$ \\
\hline
\end{tabular}

Nota: letras maiúsculas diferentes indicam se houve diferença significativa $(p \leq 0,05)$ entre os tratamentos em cada dia de análise $(p \leq 0,05)$

Média \pm Desvio Padrão

$\mathrm{nr}=$ não realizado 
Tabela 12. Valores instrumentais da cor $b^{*}$ da bisteca suína embalada em $100 \% \mathrm{CO}_{2}$, Mistura $\left(50 \% \mathrm{CO}_{2} / 50 \% \mathrm{~N}_{2}\right)$ e vácuo, durante estocagem a $0+3^{\circ} \mathrm{C}$ nos dias zero, $5,11,18,25$ e 32 de armazenamento

\begin{tabular}{cccc}
\hline & \multicolumn{3}{c}{$\mathrm{b}^{\mathrm{a}}$} \\
\hline 0 & $100 \% \mathrm{CO} 2$ & \multicolumn{1}{c}{ Mistura } & Vácuo \\
\hline 5 & $10,7^{\mathrm{a}} \pm 0,2$ & $10,7^{\mathrm{a}} \pm 0,2$ & $10,7^{\mathrm{a}} \pm 0,2$ \\
11 & $10,6^{\mathrm{a}} \pm 0,4$ & $9,8^{\mathrm{a}} \pm 1,1$ & $9,3^{\mathrm{a}} \pm 0,4$ \\
18 & $10,9^{\mathrm{a}} \pm 0,2$ & $9,9^{\mathrm{a}} \pm 0,6$ & $9,5^{\mathrm{a}} \pm 1,7$ \\
25 & $10,7^{\mathrm{a}} \pm 0,4$ & $9,8^{\mathrm{a}} \pm 0,7$ & $10,5^{\mathrm{a}} \pm 0,2$ \\
32 & $11,4^{\mathrm{a}} \pm 1,1$ & $10,8^{\mathrm{a}} \pm 0,6$ & $11,6^{\mathrm{a}} \pm 0,2$ \\
\hline
\end{tabular}

Nota: letras maiúsculas diferentes indicam se houve diferença significativa $(p \leq 0,05)$ entre os tratamentos em cada dia de análise $(p \leq 0,05)$

Média \pm Desvio Padrão

$\mathrm{nr}=$ não realizado

Tabela 13. Valores de $\mathrm{pH}$ das bistecas suinas embaladas em $100 \% \mathrm{CO}_{2}$, mistura $\left(50 \% \mathrm{CO}_{2} / 50 \% \mathrm{~N}_{2}\right)$ e vácuo, durante estocagem a $0+3^{\circ} \mathrm{C}$ nos dias zero, 5 , $11,18,25$ e 32 de armazenamento

\begin{tabular}{llll}
\hline $\mathrm{pH}$ & $\mathrm{CO}_{2}$ & Mistura & Vácuo \\
\hline 0 & $5,70^{\mathrm{a}} \pm 0,10$ & $5,70^{\mathrm{a}} \pm 0,10$ & $5,70^{\mathrm{a}} \pm 0,10$ \\
5 & $5,58^{\mathrm{b}} \pm 0,01$ & $5,67^{\mathrm{a}} \pm 0,04$ & $5,77^{\mathrm{a}} \pm 0,08$ \\
11 & $5,63^{\mathrm{a}} \pm 0,07$ & $5,80^{\mathrm{a}} \pm 0,12$ & $5,77^{\mathrm{a}} \pm 0,10$ \\
18 & $5,67^{\mathrm{a}} \pm 0,07$ & $5,80^{\mathrm{a}} \pm 0,08$ & $5,77^{\mathrm{a}} \pm 0,05$ \\
25 & $5,73^{\mathrm{a}} \pm 0,02$ & $5,74^{\mathrm{a}} \pm 0,13$ & $5,62^{\mathrm{a}} \pm 0,04$ \\
32 & $5,80^{\mathrm{a}} \pm 0,09$ & $5,73^{\mathrm{a}} \pm 0,11$ & nr \\
\hline
\end{tabular}

Nota: letras diferentes nas linhas indicam diferenças significativas $(p \leq 0,05)$ entre os tratamentos, no mesmo dia de análise Média \pm Desvio Padrão $\mathrm{nr}=$ não realizado 
Tabela 14. Valores de TBA das bistecas suínas embaladas em $100 \% \mathrm{CO}_{2}$, mistura $\left(50 \% \mathrm{CO}_{2} / 50 \% \mathrm{~N}_{2}\right)$ e vácuo, durante estocagem a $0+3^{\circ} \mathrm{C}$ nos dias zero, 5 , $11,18,25$ e 32 de armazenamento

\begin{tabular}{llll}
\hline TBA & CO2 & MIST & Vácuo \\
\hline zero & $0,001^{\mathrm{a}} \pm 0,001$ & $0,001^{\mathrm{a}} \pm 0,001$ & $0,001^{\mathrm{a}} \pm 0,001$ \\
5 & $0,048^{\mathrm{a}} \pm 0,002$ & $0,028^{\mathrm{b}} \pm 0,001$ & $0,024^{\mathrm{b}} \pm 0,000$ \\
11 & $0,011^{\mathrm{a}} \pm 0,000$ & $0,009^{\mathrm{a}} \pm 0,000$ & $0,013^{\mathrm{a}} \pm 0,000$ \\
18 & $0,018^{\mathrm{a}} \pm 0,002$ & $0,025^{\mathrm{a}} \pm 0,001$ & $0,014^{\mathrm{a}} \pm 0,000$ \\
25 & $0,009^{\mathrm{b}} \pm 0,001$ & $0,008^{\mathrm{b}} \pm 0,001$ & $0,026^{\mathrm{a}} \pm 0,001$ \\
32 & $0,013^{\mathrm{b}} \pm 0,002$ & $0,051^{\mathrm{a}} \pm 0,001$ & $\mathrm{nr}$ \\
\hline
\end{tabular}

Nota: letras diferentes nas linhas indicam diferenças significativas $(p \leq 0,05)$ entre os tratamentos, no mesmo dia de análise

Média \pm Desvio Padrão

$\mathrm{nr}=$ não realizado

Tabela 15. Valores médios do atributo sensorial de aparência "Cor marrom" da bisteca suína embalada em $100 \% \mathrm{CO}_{2}$, mistura $\left(50 \% \mathrm{CO}_{2} / 50 \% \mathrm{~N}_{2}\right)$ e vácuo, durante estocagem a $0+3^{\circ} \mathrm{C}$ nos dias zero, $5,11,18,25$ e 32 de armazenamento

\begin{tabular}{llll}
\hline Cor marrom & $\mathrm{CO}_{2}$ & Mistura & Vácuo \\
\hline 0 & $3,55^{\mathrm{a}}$ & $3,55^{\mathrm{a}}$ & $3,55^{\mathrm{a}}$ \\
5 & $1,95^{\mathrm{b}}$ & $2,76^{\mathrm{a}}$ & $3,07^{\mathrm{a}}$ \\
11 & $1,62^{\mathrm{b}}$ & $2,72^{\mathrm{a}}$ & $3,18^{\mathrm{a}}$ \\
18 & $1,92^{\mathrm{b}}$ & $2,35^{\mathrm{b}}$ & $3,25^{\mathrm{a}}$ \\
25 & $2,63^{\mathrm{b}}$ & $3,25^{\mathrm{b}}$ & $4,63^{\mathrm{a}}$ \\
32 & $3,97^{\mathrm{a}}$ & $3,96^{\mathrm{a}}$ & $\mathrm{nr}$ \\
\hline
\end{tabular}

Nota: letras diferentes nas linhas indicam diferenças significativas $(p \leq 0,05)$ entre os tratamentos, no mesmo dia de análise

$\mathrm{nr}=$ não realizado 
Tabela 16. Valores médios do atributo sensorial de aparência "Cor vermelha" da bisteca suína embalada em $100 \% \mathrm{CO}_{2}$, mistura $\left(50 \% \mathrm{CO}_{2} / 50 \% \mathrm{~N}_{2}\right)$ e vácuo, durante estocagem a $0+3^{\circ} \mathrm{C}$ nos dias zero, $5,11,18,25$ e 32 de armazenamento

\begin{tabular}{llll}
\hline Cor vermelha & $\mathrm{CO}_{2}$ & Mistura & Vácuo \\
\hline 0 & $4,32^{\mathrm{a}}$ & $4,32^{\mathrm{a}}$ & $4,32^{\mathrm{a}}$ \\
5 & $2,82^{\mathrm{a}}$ & $2,96^{\mathrm{a}}$ & $3,33^{\mathrm{a}}$ \\
11 & $2,97^{\mathrm{ab}}$ & $2,82^{\mathrm{b}}$ & $3,47^{\mathrm{a}}$ \\
18 & $1,78^{\mathrm{b}}$ & $2,34^{\mathrm{ab}}$ & $2,78^{\mathrm{a}}$ \\
25 & $2,95^{\mathrm{b}}$ & $3,36^{\mathrm{b}}$ & $4,68^{\mathrm{a}}$ \\
32 & $3,11^{\mathrm{b}}$ & $3,81^{\mathrm{a}}$ & $\mathrm{nr}$ \\
\hline
\end{tabular}

Nota: letras diferentes nas linhas indicam diferenças significativas $(p \leq 0,05)$ entre os tratamentos, no mesmo dia de análise $\mathrm{nr}=$ não realizado

Tabela 17. Valores médios do atributo sensorial de aparência "Cor nominal" da bisteca suina embalada em $100 \% \mathrm{CO}_{2}$, mistura $\left(50 \% \mathrm{CO}_{2} / 50 \% \mathrm{~N}_{2}\right)$ e vácuo, durante estocagem a $0+3^{\circ} \mathrm{C}$ nos dias zero, $5,11,18,25$ e 32 de armazenamento

\begin{tabular}{llll}
\hline Cor nominal & $\mathrm{CO}_{2}$ & Mistura & Vácuo \\
\hline 0 & $2,1^{\mathrm{a}}$ & $2,1^{\mathrm{a}}$ & $2,1^{\mathrm{a}}$ \\
5 & $1,47^{\mathrm{b}}$ & $1,95^{\mathrm{a}}$ & $1,95^{\mathrm{a}}$ \\
11 & $1,52^{\mathrm{b}}$ & $2,14^{\mathrm{a}}$ & $2,33^{\mathrm{a}}$ \\
18 & $1,64^{\mathrm{b}}$ & $1,76^{\mathrm{b}}$ & $2,29^{\mathrm{a}}$ \\
25 & $1,88^{\mathrm{b}}$ & $2^{\mathrm{b}}$ & $2,61^{\mathrm{a}}$ \\
32 & $2,28^{\mathrm{a}}$ & $2,38^{\mathrm{a}}$ & $\mathrm{nr}$ \\
\hline
\end{tabular}

Nota: letras diferentes nas linhas indicam diferenças significativas $(p \leq 0,05)$ entre os tratamentos, no mesmo dia de análise $\mathrm{nr}=$ não realizado 
Tabela 18. Valores médios do atributo sensorial de aparência "Cor amarela da gordura" da bisteca suína embalada em $100 \% \mathrm{CO}_{2}$, mistura $\left(50 \% \mathrm{CO}_{2} / 50 \% \mathrm{~N}_{2}\right)$ e vácuo, durante estocagem a $0+3^{\circ} \mathrm{C}$ nos dias zero, $5,11,18,25$ e 32 de armazenamento

\begin{tabular}{lccc}
\hline Gordura amarela & $\mathrm{CO}_{2}$ & Mistura & Vácuo \\
\hline 0 & $1,93^{\mathrm{a}}$ & $1,93^{\mathrm{a}}$ & $1,93^{\mathrm{a}}$ \\
5 & $1,67^{\mathrm{b}}$ & $2,36^{\mathrm{a}}$ & $1,6^{\mathrm{b}}$ \\
11 & $1,22^{\mathrm{b}}$ & $1,47^{\mathrm{b}}$ & $2,04^{\mathrm{a}}$ \\
18 & $1,28^{\mathrm{a}}$ & $1,09^{\mathrm{a}}$ & $1,53^{\mathrm{a}}$ \\
25 & $1,46^{\mathrm{a}}$ & $1,42^{\mathrm{a}}$ & $1,73^{\mathrm{a}}$ \\
32 & $1,4^{\mathrm{a}}$ & $0,9^{\mathrm{b}}$ & $\mathrm{nr}$ \\
\hline
\end{tabular}

Nota: letras diferentes nas linhas indicam diferenças significativas $(p \leq 0,05)$ entre os tratamentos, no mesmo dia de análise $\mathrm{nr}=$ não realizado

Tabela 19. Valores médios do atributo sensorial de aparência "Cor do osso" da bisteca suína embalada em $100 \% \mathrm{CO}_{2}$, mistura $\left(50 \% \mathrm{CO}_{2} / 50 \% \mathrm{~N}_{2}\right)$ e vácuo, durante estocagem a $0+3^{\circ} \mathrm{C}$ nos dias zero, $5,11,18,25$ e 32 de armazenamento

\begin{tabular}{llll}
\hline Cor do osso & $\mathrm{CO}_{2}$ & Mistura & Vácuo \\
\hline 0 & $1,94^{\mathrm{a}}$ & $1,94^{\mathrm{a}}$ & $1,94^{\mathrm{a}}$ \\
5 & $1,97^{\mathrm{a}}$ & $1,76^{\mathrm{a}}$ & $2,1^{\mathrm{a}}$ \\
11 & $1,56^{\mathrm{c}}$ & $2,16^{\mathrm{b}}$ & $2,86^{\mathrm{a}}$ \\
18 & $1,15^{\mathrm{b}}$ & $1,34^{\mathrm{b}}$ & $3,25^{\mathrm{a}}$ \\
25 & $1,93^{\mathrm{c}}$ & $2,91^{\mathrm{b}}$ & $4,47^{\mathrm{a}}$ \\
32 & $2,35^{\mathrm{b}}$ & $3,11^{\mathrm{a}}$ & $\mathrm{nr}$ \\
\hline
\end{tabular}

Nota: letras diferentes nas linhas indicam diferenças significativas $(p \leq 0,05)$ entre os tratamentos, no mesmo dia de análise $\mathrm{nr}=$ não realizado 
Tabela 20. Valores médios do atributo sensorial de odor, observando a presença de "Odor estranho" da bisteca suina embalada em $100 \% \mathrm{CO}_{2}$, mistura $\left(50 \% \mathrm{CO}_{2} / 50 \% \mathrm{~N}_{2}\right)$ e vácuo, durante estocagem a $0+3^{\circ} \mathrm{C}$ nos dias zero, 5 , $11,18,25$ e 32 de armazenamento

\begin{tabular}{llll}
\hline Odor estranho & $\mathrm{CO}_{2}$ & Mistura & Vácuo \\
\hline 0 & $0,77^{\mathrm{a}}$ & $0,77^{\mathrm{a}}$ & $0,77^{\mathrm{a}}$ \\
5 & $1,53^{\mathrm{a}}$ & $1,12^{\mathrm{a}}$ & $1,36^{\mathrm{a}}$ \\
11 & $0,47^{\mathrm{c}}$ & $1,57^{\mathrm{b}}$ & $2,86^{\mathrm{a}}$ \\
18 & $0,98^{\mathrm{a}}$ & $1,81^{\mathrm{b}}$ & $5,31^{\mathrm{b}}$ \\
25 & $1,42^{\mathrm{c}}$ & $3,42^{\mathrm{b}}$ & $5,39^{\mathrm{a}}$ \\
32 & $3,2^{\mathrm{b}}$ & $4,58^{\mathrm{a}}$ & $\mathrm{nr}$ \\
\hline
\end{tabular}

Nota: letras diferentes nas linhas indicam diferenças significativas $(p \leq 0,05)$ entre os tratamentos, no mesmo dia de análise $\mathrm{nr}=$ não realizado

Tabela 21. Valores médios do atributo sensorial de odor, caracterizando o "Tipo de odor" percebido da bisteca suína embalada em $100 \% \mathrm{CO}_{2}$, mistura $\left(50 \% \mathrm{CO}_{2} / 50 \% \mathrm{~N}_{2}\right)$ e vácuo, durante estocagem a $0+3^{\circ} \mathrm{C}$ nos dias zero, 5 , $11,18,25$ e 32 de armazenamento

\begin{tabular}{llll}
\hline Tipo de odor & $\mathrm{CO}_{2}$ & Mistura & Vácuo \\
\hline 0 & $1^{\mathrm{a}}$ & $1^{\mathrm{a}}$ & $1^{\mathrm{a}}$ \\
5 & $2^{\mathrm{a}}$ & $2^{\mathrm{a}}$ & $2^{\mathrm{a}}$ \\
11 & $3^{\mathrm{a}}$ & $2^{\mathrm{b}}$ & $1^{\mathrm{c}}$ \\
18 & $2^{\mathrm{b}}$ & $2^{\mathrm{b}}$ & $5^{\mathrm{a}}$ \\
25 & $2^{\mathrm{c}}$ & $3^{\mathrm{b}}$ & $5^{\mathrm{a}}$ \\
32 & $4^{\mathrm{a}}$ & $4^{\mathrm{a}}$ & $\mathrm{nr}$ \\
\hline
\end{tabular}

Nota: letras diferentes nas linhas indicam diferenças significativas $(p \leq 0,05)$ entre os tratamentos, no mesmo dia de análise $\mathrm{nr}=$ não realizado 
Tabela 22. Valores médios do atributo sensorial "Qualidade geral" da bisteca suína embalada em $100 \% \mathrm{CO}_{2}$, mistura $\left(50 \% \mathrm{CO}_{2} / 50 \% \mathrm{~N}_{2}\right)$ e vácuo, durante estocagem a $0+3^{\circ} \mathrm{C}$ nos dias zero, $5,11,18,25$ e 32 de armazenamento

\begin{tabular}{llll}
\hline Qualidade Geral & $\mathrm{CO}_{2}$ & Mistura & Vácuo \\
\hline 0 & $7,56^{\mathrm{a}}$ & $7,56^{\mathrm{a}}$ & $7,56^{\mathrm{a}}$ \\
5 & $7,35^{\mathrm{a}}$ & $6,65^{\mathrm{a}}$ & $6,8^{\mathrm{a}}$ \\
11 & $7,78^{\mathrm{a}}$ & $6,18^{\mathrm{b}}$ & $5,26^{\mathrm{c}}$ \\
18 & $6,9^{\mathrm{a}}$ & $6,05^{\mathrm{b}}$ & $2,8^{\mathrm{c}}$ \\
25 & $6,77^{\mathrm{a}}$ & $5,11^{\mathrm{b}}$ & $3,21^{\mathrm{c}}$ \\
32 & $4,97^{\mathrm{a}}$ & $4,13^{\mathrm{b}}$ & $\mathrm{nr}$ \\
\hline
\end{tabular}

Nota: letras diferentes nas linhas indicam diferenças significativas $(p \leq 0,05)$ entre os tratamentos, no mesmo dia de análise $\mathrm{nr}=$ não realizado 


\section{REFERÊNCIAS BIBLIOGRÁFICAS}

BARTKOWSKI, L.; DRYDEN, F.D.; MARCHELLO, J.A. Quality changes of beef steaks stored in controlled gas atmospheres containing high or low levels of oxygen. Journal of Food Protection, v.45, n.2, p.41-45, 1982.

BELL, R.G.; PENNEY, N.; MOORHEAD, S.M. The retail display life of steaks prepared from chill stored vaccum and carbon dioxide packed sub-primal beef cuts. Meat Science, v.42, n.4, p.165-178, 1996.

BOMAR, M.T. Rapid method for the determination of bacterial surface contamination in carcasses. Alimentaria, v.24, n.2, p.55-57, 1985.

BORCH, E.; KANT-MUERMANS, M.L.; BLIXT, Y. Bacterial spoilage of meat and cured meat products. International Journal of Food Microbiology, v.33, n.3, p.103-120, 1996.

BRASIL. Ministério da Agricultura e do Abastecimento. Agência Nacional de Vigilância Sanitária (ANVISA). Resolução $n^{\circ} 12$ de 02 de janeiro de 2001. Diário Oficial da União, n.7, jan. 2001. Seção 1, p.45-53. Aprova os padrões microbiológicos sanitários de diferentes grupos alimentícios para fins de registro e fiscalização.

BUTLER, O.D.; BRATZLER, L.J.; MALLMANN, W.L. The effect of bacteria on the colour of prepackaged retail beef cuts. Food Technology, v.7, n.10, p.397-400, 1953. 
BUYS, E.M.; KRUGER, J.; NORTJÉ, G.L. Centralised bulk pré-packaging of fresh pork retail cuts in various gas atmospheres. Meat Science, v.36, n.4, p.293-308, 1994.

CHURCH, P.N. Developments in modified atmosphere packaging and related technologies. Trends in Food Science \& Technology, v.5, n.4, p.345-352, 1994.

CLARK, D.S.; BURKI, T. Oxygen requirements of strains of Pseudomonas and Achromobacter. Canadian Journal of Microbiology, v.18, n.3, p.321-326, 1972.

CLARK, D.S.; LENTZ, C.P. Use of carbon dioxide for extending shelf-life of prepackaged beef. Canadian Institute of Food Science and Technology Journal, v.5, n.4, p.175-178, 1972.

DAINTY, R.H.; MACKEY, B.M. The relationship between the phenotypic properties of bacteria from chill-stored meat and spoilage processes. Journal of Applied Bacteriology, v.73, p.103S-114S, 1992. Symposium Supplement, 21.

DAMASIO, M.H.; COSTELL, E. Analisis sensorial descriptiva: generación de descriptores y selección de catadores. Revista Agroquimica Technologia Alimentária, v.32, n.2, p.165-178, 1991.

DANIELS, J.A.; KRISHNAMURTHI, R.; RIZVI, S.S.H. A review of effects of carbon dioxide on microbial growth and food quality. Journal of Food Protection, v.45, n.5, p.532-537, 1985.

DAY, B.P.F. Guidelines for the good manufacturing and handling of modified atmosphere packed food products. Gloucestershire: The Campden Food and Drink Research Association, 1992. 79p. (Technical manual,34)

DJENANE, D.; SÁNCHEZ-ESCALANTE, A.; BELTRÁN, J.A.; RONCÁlES, P. Extension of the retail display life of fresh beef packaged in modified atmosphere by varying lighting conditions. Journal of Food Science, v.66, n.1, p.181-186, 2001. 
DOHERTY, A.M.; ALLEN, P. The effect of oxygen scavengers on the color stability and shelf-life of $\mathrm{CO}_{2}$ Master packaged pork. Journal of Muscle Foods, v.9, n.2, p.351363, 1998.

DROSINOS, E.H.; BOARD, R.G. Microbial and physicochemical attributes of minced lamb: sources of contamination with pseudomonas. Food Microbiological, v.12, n.3, p.189-197, 1995.

EGAN, A.F.; SHAY, B.J. Significance of lactobacilli and film permeability in the spoilage of vacuum-packaged beef. Journal of Food Science, v.47, n.6, p.11191122, 1982.

ENFORS, S.O.; MOLIN, G.; TERNSTROM, A. Effect of packaging under carbon dioxide, nitrogen or air on the microbial flora of pork stored at $4^{\circ} \mathrm{C}$. Journal of Food Protection, v.47, n.3, p.197-208, 1979.

ERNST, L.J. Marketing fresh meat in the deoxymyoglobin state. In: ANNUAL RECIPROCAL MEAT CONFERENCE, 33., Chicago, 1980. Proceedings. Chicago: Chicago National Live Stock And Meat Board, 1980. p.37-40.

FARBER, J.M. Microbiological aspects of modified atmosphere packaging technology: a review. Journal of Food Protection, v.54, n.1, p.58-70, 1991.

FERNANDEZ, P.S.; GEORGE, S.M.; SILLS, C.S.; PECK, M.V. The development of predictive models that describe the effect of carbon dioxide, $\mathrm{pH}$, temperature, and $\mathrm{NaCl}$ on the growth and survival of foodborne pathogenic bactéria. In: ANNUAL MEETING SOCIETY APPLIED BACTERIOLOGY, 64., London, 1995. Program Abstracts. London: Meet Applied Bacteriology, 1995. p.18-34.

FOX, J.B. Jr. The chemistry of meat pigments. Journal of Agricultural and Food Chemistry, v.14, n.3, p.207-310, 1966. 
FRANCO, B.D.G.M.; LANDGRAF, M. Microbiologia dos alimentos. São Paulo: Atheneu, 1996. 177p.

GARCIA-LOPEZ, M.L.; PRIETO, M.; OTERO, A. The physiological attributes of gramnegative bactéria associated with spoilage of meat and products. In: DAVIES, A.; BOARD, R. The microbiology of meat and poltry. 1.ed. London: Blackie Academic \& Professional, 1998. p.1-34.

GILL, C.O. The control of microbial spoilage in fresh meats. In: PEARSON, A.M.; DUTSON, T.R. (Ed.). Advances in meat research. New York: AVI Publishing Co., 1986. v.2, p.49-81.

GILL, C.O. The solubility of carbon dioxide in meat. Meat Science, v.22, n.1, p.65-71, 1988.

GILL, C.O. Extending the storage life of raw meat. I. Preservative atmospheres. Saskatoon: University of Saskatchewan, Western Canada Research Group on Extended Storage of Meat and Meat Products, Department of Applied Microbiology and Food Science, 1991. p.329-503. (Technical Bulletin, 1)

GILL, C.O. Application of preservative packaging of chilled raw meats. In: CANADIAN MEAT SCIENCE ASSOCIATION SYMPOSIUM, 32., Toronto, 1992. Proceedings. Toronto: ACVI, 1992. p.1-8.

GILL, C.O.; HARRISON, J.C.L. The storage life of chilled pork packaged under carbon dioxide. Meat Science, v.26, n.3, p.313-324, 1989.

GILL, C.O. Extending the storage life of raw chilled meats. Meat Science, v.43, n.2, p.99-109, 1996.

GILL, C.O.; NEWTON, K.G. The development of aerobic spoilage microbiota in meat stored at chill temperatures. Journal of Applied Bacteriology, v.43, n.2, p.189195, 1977. 
GILL, C.O.; PENNEY, N. The effect of the initial gas volume to meat weight ratio on the storage life of chilled beef packaged under carbon dioxide. Meat Science, v.22, n.1, p.53-63, 1988.

GILL, C.O.; MOLIN, G. Modified atmosphere and vacuum packaging. In: RUSSEL, N.J.; GOLD, G.W (Ed.). Food preservation. Glasgow: Scotland; New York: Blackie and $A V I, 1991$. p.172-199.

GILL, C.O.; JONES, T. The display of retail-packaged beef steaks after their storage in master packs under various atmospheres. Meat Science, v.38, n.3, p.385-396, 1994.

GILL, C.O.; McGINNIS, J.C. The effects of residual oxygen concentration and temperature on the degradation of the colour of beef packaged under oxygendepleted atmospheres. Meat Science, v.39, n.1, p.387-394, 1995.

GILL, C.O.; McGINNIS, J.C. The use of oxygen scavengers to prevent the transient discoloration of ground beef packaged under controlled oxygen-depleted atmospheres. Meat Science, v.41, n.1, p.19-20,1995.

GOKALP, H.Y.; OCKERMAN, H.W.; PLIMPTON, R.P.; PARRET, N.A.; CAHILL, V.R. Effect of different packaging methods on objective quality, characteristics of frozen and stored cow beef. Journal of Food Science, v.43, n.2, p.297-300, 1978.

GOVINDARAJAN, S. Fresh meat colour. CRC Critical Reviews in Food Technology, v.4, n.1, p.117-140, 1973.

GRAY, J.I.; GOMAA, E.A.; BUCKLEY, D.J. Oxidative quality and shelf-life of meats. Meat Science, v.43, n.2, p.111-123, 1996.

GREENE, B.E. Lipid oxidation and pigment changes in raw beef. Journal of Food Science, v.34, n.3, p.110-113, 1969. 
HERMANSEN, P. Comparision of modified atmosphere versus aacuum packaging to extend the shelf-life of retail fresh meat cuts. In: RECIPROCAL MEAT CONFERENCE, 35., Chicago, 1983. Proceedings. Chicago: Chicago National Live Stock And Meat Board, 1983. p.60-64.

HOOD, D.E.; MEAD, G.C. Modified atmosphere storage of fresh meat and poultry. In: PARRY, R.T. Principles and applications of modified atmosphere packaging of food. London: Blackie Academic \& Professional, 1993. p.269-298.

HOOD, D.E. Technical aspects of vacuum packaging and pre-packaging fresh beef. In: BEEF PROCESSING AND MARKETING INTERNATIONAL SYMPOSIUM, 27., Dublin, 1971. Proceedings. Dublin: Beef Processing And Marketing International, 1971. p.24-39.

HOOD, D.E. Factors affecting the rate of metmyoglobin accumulation in prepackaged beef. Meat Science, v.4, n.2, p.247-265, 1980.

HOTCHKISS, J.H. Experimental approaches to determining the safety of food packaged in modified atmospheres. Food Technology, v.42, n.9, p.55-64, 1988.

HUNT, M.C.; KROPF, D.H. Color and appearance. In: PEARSON, A.M.; DUTSON, T.R. Advances in meat research: reestructured meat and poultry products. New York: AVI Book, 1987. v.3, p.125-159.

INTERNATIONAL COMISSION ON MICROBIOLOGICAL SPECIFICATIONS FOR FOODS (ICMSF). Microorganisms in foods: their significance and methods of enumeration. 2.ed. Toronto: University of Toronto Press, 1978. v.1.

JACKSON, T.C.; ACUFF, C.R.; VANDERZANT, C.; SHARP, T.R.; SAVEL, J.W. Identification and evaluation of volatile compounds of vacuum and modified atmosphere packaged beef strip loins. Meat Science, v.31, n.2, p.175-190, 1992. 
JAKOBSEN, M.; BERTELSEN, G. Color stability and lipid oxidation of fresh beef: development of a response surface model for predicting the effects of temperature, storage time, and modified atmosphere composition. Meat Science, v.54, n.1, p.49$57,2000$.

JEREMIAH, L.E. Packaging alternatives to deliver fresh meats using short-or long-term distribution. Food Research International, v.34, n.3, p.749-772, 2001.

JEREMIAH, L.E.; GIBSON, L.L. The influence of packaging and storage time on the retail properties and case-life of retail-ready beef. Food Research International, v.34, n.3, p.621-631, 2001.

JEYAMKONDAN, S.; JAYAS, D.S.; HOLLEY, R.A. Review of centralized packaging systems for distribution of retail-ready meat. Journal of Food Protection, v.63, n.6, p.796-804, 2000.

KAKOURI, A.; NYCHAS, G.J.E. Storage of poultry meat under modified atmospheres or vacuum packs: possible role of microbial metabolites as indicator of spoilage. Journal of Applied Bacteriology, v.76, n.2, p.163-142, 1994.

KING, A.D.; NAGEL, C.W. Influence of carbon dioxide upon the metabolism of Pseudomonas aeruginosa. Journal of Food Science, v.40, n.2, p.362-366, 1975.

KRAFT, A.A.; AYRES, J.C. Post-mortem changes in stored meats. IV. Effect of packaging material on keeping quality of self-service meats. Food Technology, v.6, n.1, p.8-12, 1952.

KROPF, D.H. Effects of retail display conditions on meat color. In: ANNUAL RECIPROCAL MEAT CONFERENCE, 33., Chicago, 1980. Proceedings. Chicago: Chicago National Live Stock And Meat Board, 1980. p.15-32. 
KROPF, D.H.; HUNT, M.C.; PISKE, D. Color formation and retention in fresh meat. In: MEAT INDUSTRY RESEARCH CONFERENCE, 21., Chicago, 1985. Proceedings. Chicago: Chicago National Live Stock And Meat Board, 1985. p.67-82.

LEDWARD, D.A. Post-slaughter influences on the formation of metmyoglobin in beef muscles. Meat Science, v.15, n.3, p.149-171, 1985.

LIOUTAS, T.S. Challenges of controled and modified atmosphere packaging: a food company's perspective. Food Technology, v.42, n.9, p.78-79, 1988.

LUNO, M.; BELTRAN, J.A.; RONCALES, P. Shelf-life extension and colour stabilisation of beef packaged in a low $\mathrm{O}_{2}$ atmosphere containing $\mathrm{CO}$ : loin steaks and ground meat. Meat Science, v.48, n.2, p.75-84, 1998.

MANO, S.B.; GARCIA DE FERNANDO, G.D.; LÓPEZ, D.; SELGAS, M.D.; GARCIA, M.L.; CAMBERO, M.I.; ORDONEZ, J.A . Growth I survival of Listeria monocytogens on refrigerated pork and turkey packaged under modified atmospheres. Journal of Food Safety, v.42, n.2, p.81-93, 1995.

MANU-TAIWAH, W.; MYERS, D.J.; OLSON, D.G.; MOLINS, R.A. Survival and growth of Listeria monocytogenes and Yersinia enterocolitica in pork chops packaged under modified gas atmospheres. Journal of Food Science, v.58, n.3, p.475-479, 1993.

MCMULLEN, L.M.; STILES, M.E. Changes in microbial parameters and gas composition during modified atmosphere storage of fresh pork loins cuts. Journal of Food Protection, v.54, n.10, p.778-783, Oct. 1991.

MEAD, G.C.; ADAMS, B.W. Pseudomonas in foods. Britsh Poultry Science, v.18, n.6, p.661-667, 1997.

MINOLTA CO. LTD. Precise color commuication. Osawa, 1998. 59p. 
MOLIN, G. Modified atmospheres. In: LUND, B.M.; BAIRD-PARKER, T.C.; CRAHAME, W.G. The microbiological safety and quality of food. Maryland: Aspen Publishers, 2000. cap.10, p.214-234.

MUNSELL, A.H. Book of color. 3.ed. Baltimore: Mcbeth Division of Kolmorgen Instruments Corporation, 1976. 422p.

NATTRESS, F.M.; JEREMIAH, L.E. Bacterial mediated off-flavors in retail-ready beef after storage in controlled atmospheres. Food Research International, v.33, n.4, p.743-748, 2000.

NEWTON, K.G.; GILL, C.O. The development of the anaerobic spoilage microbiota of meat stored at chill temperatures. Journal of Applied Bacteriology, v.44, n.1, p.91-95, 1978.

OGILVY, W.S.; AYRES, J.C. Post-mortem changes in stored meats. II. The effect of atmospheres containing carbon dioxide in prolonging the storage life cut-up chicken. Food Technology, v.5, n.3, p.97-102, 1951.

O'GRADY, M.N.; MONAHAN, F.J.; BURKE, R.M.; ALLEN, P. The effect of oxygen level and exogenous $\alpha$-tocopherol on the oxidative stability of minced beef in modified atmosphere packs. Meat Science, v.55, n.1, p.39-45, 2000.

O'KEEFFE, M.; HOOD, D.E. Anoxic storage of fresh beef. 2: color stability and weight loss. Meat Science, v.5, n.1, p.267-281, 1980-1981.

ORDÓÑEZ, J.A.; DE PABLO, B.; PEREZ DE CASTRO, B. Selected chemical and microbiological changes in refrigerated pork stored in carbon dioxide and oxygen enriched atmospheres. Journal Agriculture Food

Chemistry, v.39, n.4, p.668-672, 1991. 
PARRY, R.T. Introduction. In: PARRY, R.T. Principles and aplications of modified atmosphere packaging of food. London: Blackie Academic \& Professional, 1993. cap.1, p.1-18.

PIERSON, M.D.; COLLINS-THOMPSON, D.L.; ORDAL, Z.J. Microbiological, sensory and pigment changes of aerobically and anaerobically packaged beef. Food Technology, v.24, n.10, p.1171-1175, 1970.

REINBOLD, G.W. Indicador organisms in dairy products. Food Technology, v.37, n.6, p.111-113, 1983.

RENERRE, M. Review: factors involved in the discoloration of beef meat. International Journal of Food Science and Technology, v.25, n.4, p.613-663, 1990.

RIKERT, J.A.; BRESSLAR, L.; BALL, C.O.; STIER, E.F. Factors affecting quality of prepackaged meat. II: color studies of air and oxygen under different pressures upon color of product. Food Technology, v.11, n.6, p.625-632, 1957.

RIZVI, S.S.H. Requirements for foods packaged in polymeric films. CRC Critical Reviews in Food Science and Nutrition, v.14, n.2, p.111-134, 1981.

ROUSSET, S.; RENERRE, M. Comparision of different packaging systems for the storage of fresh beef. Sciences des Aliments, v.10, n.4, p.737-747, 1990.

SÃO PAULO. Secretaria Estadual da Saúde. Decreto $n^{0} 12.342$ de 27 de setembro de 1978. Diário Oficial do Estado, 21 out. 1978. p.128-337. Dispõe sobre o regulamento da promoção, preservação e recuperação da saúde.

SARANTÓPOULOS, C.I.G.L.; SOLER, R.M. Embalagens com atmosfera modificada / controlada. In: NOVAS tecnologias de acondicionamento de alimentos: embalagens flexíveis e semi-rígidas. Campinas: ITAL / SBCTA, 1988. cap.5, p.105-140. 
SARANTÓPOULOS, C.I.G.L.; PIZZINATTO, A. Fatores que afetam a cor das carnes. Coletânea ITAL, v.20, n.1, p.1-12, 1990.

SARANTÓPOULOS, C.I.G.L. Embalagem a vácuo e com atmosfera modificada para carnes frescas: embalagem para produtos cárneos. Campinas: ITAL, 1991. cap.1, p.1-20.

SARANTÓPOULOS, C.I.G.L;; SOLER, R.M. Embalagens com atmosfera modificada/controlada. Catálogo Brasileiro de Produtos e Serviços, v.28, n.3, p.32-42, 1994.

SARANTÓPOULOS, C.I.L.; ALVES, R.M.V.; ARIMA, H.K.; CONTRERAS, C.J.C.; GOMES, T.C. Estabilidade de carne bovina em atmosfera modificada após maturação em embalagem à vácuo. Coletânea ITAL, v.26, n.2, p.143-154, 1996.

SARANTÓPOULOS, C.I.G.L.; OLIVEIRA, L.M.; PADULA, M.; COLTRO, L; ALVES, R.M.V.; GARCIA, E.E.C. Embalagens plásticas flexiveis: principais polímeros e avaliação de propriedades. Campinas: ITAL, CETEA, 2002. 247p.

SEIDEMANN, S.C.; CARPENTER, Z.L.; SMITH, G.C.; DILL, C.W.; VANDERZANT, C. Physical and sensory characteristics of pork packaged in various gas atmospheres. Journal of Food Protection, v.42, n.4, p.317-322, 1979.

SEIDEMAN, S.C.; VANDERZANT, C.; SMITH, G.C.; DILL, C.W.; CARPENTER, Z.L. Appearance of beef, pork and lamb stored in vacuum or modified gas atmospheres. Journal of Food Protection, v.43, n.2, p.252-258, 1980.

SEIDEMAN, S.C.; DURLAND, R.R. Vacuum packaging of fresh beef: a review. Journal of Food Quality, v.6, n.1, p.29-47, 1983.

SHAY, B.J.; EGAN, A.F. Studies of possible tecniques for extending the storage life of chilled pork. Food Technology in Australia, v.18, n.3, p.144-146, 1986. 
SMITH, J.L.; BUCHANAN, R.L.; PALUMBO, S.A . Effect of food environment on staphylococcal enterotoxin synthesis: a review. Journal of Food Protection, v.46, n.6, p.545-555, 1983.

SORHEIM, O.; GRINI, J.A.; NISSEN, H.; ANDERSEN, H.J.; LEA, P. Pork loin stored in carbon dioxide: colour and microbiologiacal shelf life. Fleischwirtsch, v.75, n.4, p.679-681, 1995.

SORHEIM, O.; KROPF, D.H.; HUNT, M.C.; KARWOSKI, M.T.; WARREN, K.E. Effects of modified gas atmosphere packaging on pork loin colour, display life and drip loss. Meat Science, v.43, n.2, p.203-212, 1996.

STANDBRIDGE, L.H.; DAVIES, A.R. The microbiology of chill-stored meat. In: DAVIES, A.; BOARD, R. The microbiology of meat and poltry. London: Blackie Academic \& Professional, 1998. p.174-219.

STILES, M.E. Modified atmosphere packaging of food. New York: Horwood, 1991. p.118-147: Modified atmosphere packaging of meat, poultry, and their products.

TARLADGIS, B.G.; WATTS, B.M.; YOUNATHAN, M.T. A distilation method for the quantitative determination of malonaldehyde in rancid foods. The Journal of the American Oil Chemists' Society, v.37, n.1, p.44-48, 1960.

TAYLOR, A.A. Retail packaging systems for fresh meat. In: MEAT SCIENCE AND TECHNOLOGY INTERNATIONAL SYMPOSIUM, 11., Chicago, 1982. Proceedings. Chicago: National Live Stock And Meat Board, 1982. p.387.

TAYLOR, A.A.; MACDOUGALL, D.B. Fresh beef packaged in mixtures of oxygen and carbon dioxide. Journal of Food Technology, v.8, n.10, p.453-461, 1973. 
VANDERZANT, C.; SPLITTSTOESSER, D.F. Compendium of methods for the microbiological examination of foods. 3.ed. Washington: American Public Health Association (APHA), 1992. p.445.

VELAZCO, J. Aspectos importantes en la medición del pH. Carne Technological, v.15, n.4, p.329, jul./ago. 2001.

WIMPFHIMER, L.; ALTMAN, N.S.; HOTCHKISS, J.H. Growth of Listeria monocytogenes serotype 4 and competitive spoilage organism in raw chicken packaged under modified atmospheres and in air. Institute of Journal Food Microbiology, v.11, n.4, p.205-214, 1990.

YOUNG, O.A.; PRIOLO, A.; SIMMONS, N.J.; WEST, J. Effects of rigor attainment temperature on meat blooming and color on display. Meat Science, v.52, n.1, p.4756, 1999.

ZHAO, Y.; WELLS, J.H.; MCMILLIN, K.W. Application of dynamic modified atmosphere packaging systems for fresh red meats: review. Journal of Muscles Foods, v.5, n.2, p.299-328, 1994. 